\title{
ESTUDO DE FATORES SAZONAIS RELACIONADOS À TRANSMISSÃO DE Xylella fastidiosa EM POMARES DE CITROS
}

\author{
ÉRICA FRAZÃo PEREIRA \\ Engenheira Agrônoma
}

Orientador: Prof. Dr. JOÃO ROBERTO SPOTTI LOPES

Dissertação apresentada à Escola Superior de Agricultura "Luiz de Queiroz", Universidade de São Paulo, para obtenção do título de Mestre em Ciências Área de Entomologia.

PIRACICABA

Estado de São Paulo - Brasil

Dezembro - 2000 


\section{ERRATA}

Página

10 Acrescentar classificadores das espécies vetoras: Acrogonia virescens (Metcalf), Homalodisca ignorata (Melichar), Macugonalia leucomelas (Walker) e Parathona.gratiosa (Blanchard).

11 Acrescentar nomes científicos das espécies vegetais: amieiro (Alnus rhombifolia), freixo (Fraxinus latifolia), negundo (Acer negundo), urtiga (Urtica dioica) e salgueiro (Salix sp.).

17 Consertar o parágrafo: Menores índices de isolamento de $X$. fastidiosa têm sido obtidos na primavera, com aumento no outono (Chang \& Yonce, 1987). Estudando a flutuação populacional da bactéria em uma variedade de ameixeira suscetível à escaldadura das folhas, Leite et al. (1997) observaram maior pico populacional no mês de maio, e menor, em novembro.

20 Em cada pomar foi selecionado um talhão com incidência de CVC menor que $22 \%$.

21 Na Tabela 1, substituir acetato por acefato.

28 Substituir gilete por lâmina.

33 Última linha: substituir das cigarinhas por de 5 cigarrinhas.

37 Na Tabela 3, considerar os valores de P menores que 0,001 , ao invés de 0.

39 A espécie de cigarrinha Sonesimia grossa não foi capturada por plantas-iscas, apenas Ferrariana trivittata.

39 Último parágrafo ( $4^{\mathrm{a}}$ linha), substituir cultivos de fumo por plantas cultivadas.

56 Na figura A, substituir precipitacão pluviométrica por \% amostras positivas.

62 Na Tabela 11, a proporção de ramos positivos avaliados por DAS-ELISA é de $0 / 5$. 


\title{
Dados Internacionais de Catalogaçāo na Publicaçāo (CIP) DIVISĀO DE BIBLIOTECA E DOCUMENTAÇĀO - Campus "Luiz de Queiroz"/USP
}

\author{
Pereira, Érica Frazão \\ Estudo de fatores sazonais relacionados à transmissão de Xylella fastidiosa em \\ pomares de citros / Érica Frazão Pereira. - - Piracicaba, 2000. \\ 82 p. : il. \\ Dissertação (mestrado) - Escola Superior de Agricultura Luiz de Queiroz, 2000. \\ Bibliografia. \\ 1. Bactéria gram-negativa 2. Cigarrinha 3. Clorese-variegada-dos-citros 4. Doença \\ de planta 5. Transmissão de doença 6 . Variação sazonal 7. Xilema I. Título
}

CDD 634.3

"Permitida a cópia total ou parcial deste documento, desde que citada a fonte - $\mathbf{O}$ autor" 


\section{DEDICO}

Aos meus pais: Jomar e Regina,

Por todo carinho, confiança e estímulos

\section{OFEREÇO}

Aos meus irmãos: Gláucia, Natali, Jomar Jr. e Raphael, Pelo apoio e incentivo

Ao companheiro e amigo: Paulo Rogério,

Por todo carinho, auxilio e compreensão 


\section{AGRADECIMENTOS}

A Deus, fonte inesgotável de sabedoria e amor, agradeço a oportunidade de estar aqui.

A todos aqueles que direta ou indiretamente auxiliaram neste trabalho, e em especial:

À minha familia, base do que sou, e grande incentivadora do meu progresso pessoal.

Ao Professor Dr. João Roberto Spotti Lopes, pela orientação, ensinamentos e confiança.

Ao companheiro Paulo, pelo apoio, amor e motivação.

Aos amigos Adriane, Charles, Eduardo, Luciano, Genésio, Marina, Matê, Mônica, Ranyse, Reymar, Rodrigo, Rogério, Rosangela, Sandra, Simone e Teresinha, pela amizade, auxílio, incentivo e pelos momentos de descontração.

Aos estagiários e amigos Gilson, Helen, Natanael, Paulo César e Renata, pela amizade e auxílio na condução dos experimentos.

Ao Prof. Dr. Armando Bergamim Filho, pelas discussões que aprimoraram essa pesquisa.

Aos Professores e Funcionários do Departamento de Entomologia, Fitopatologia e Zoologia Agrícola, pelos ensinamentos, amizade e colaboração durante o curso.

Ao Fundo Paulista de Defesa da Citricultura (FUNDECITRUS), pela bolsa concedida e apoio financeiro ao projeto.

Ao Conselho de Apoio à Pesquisa (CAPES) pela bolsa de estudos.

À Fundação de Amparo à pesquisa do Estado de São Paulo (FAPESP) pelo suporte financeiro e técnico ao projeto.

À Denise Regina Silva Abreu, do Instituto Agronômico de Campinas, pela colaboração no fornecimento dos dados climáticos.

Ao Prof. Dr. Paulo Sentelhas, do Departamento de Física e Meteorologia, pelo auxílio na avaliação dos dados climáticos e discussões.

Ao Prof. Dr. José Eduardo Corrente, do Departamento de Matemática e Estatística da ESALQ-USP, pelo auxílio na análise estatística dos dados, pelo apoio e incentivo.

Às Bibliotecárias Eliana e Silvia, pela correção das referências bibliográficas. 


\section{SUMÁRIO}

Página

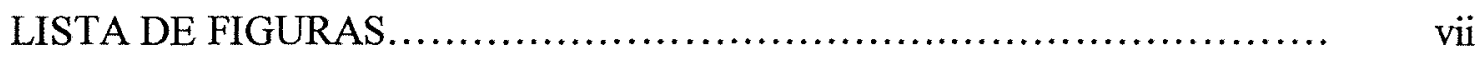

LISTA DE TABELAS..................................................

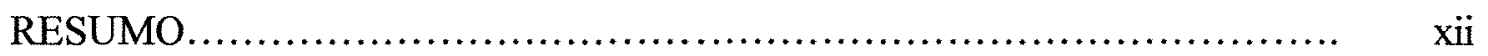

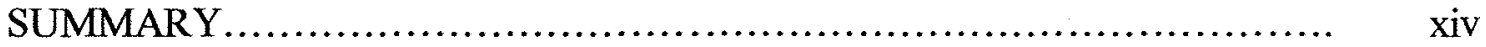

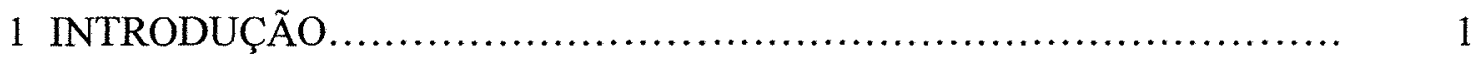

2 REVISÃO DE LITERATURA............................................... 3

2.1Clorose variegada dos citros e seu agente causal............................ 3

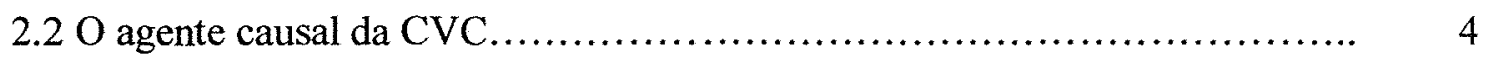

2.3 Deteç̧ão de $X$. fastidiosa e diagnose da CVC.............................. 5

2.4 Transmissão de $X$. fastidiosa ............................................. 8

2.4.1 Grupos de vetores e mecanismos de transmissão ........................... 8

2.4.2 Transmissão de $X$. fastidiosa em citros................................. 10

2.5 Dinâmica populacional dos vetores de $X$. fastidiosa em citros................ 12

2.6 Epidemiologia de doenças causadas por $X$. fastidiosa ........................ 14

3 MATERIAL E MÉTODOS ............................................... 20

3.1 Levantamento populacional.............................................. 22

3.2 Avaliação da infectividade natural dos vetores............................. 26

3.3 Flutuação populacional de $X$. fastidiosa em árvores com CVC............... 27

3.4 Efeito da época de inoculação na sobrevivência de $X$. fastidiosa em árvores cítricas.......................................................... 30

3.4.1 Inoculação mecânicas................................................... 31

3.4.2 Inoculação com cigarrinhas vetoras................................... 33

4 RESULTADOS E DISCUSSÃO ......................................... 35

4.1 Levantamento populacional de vetores nas áreas estudadas................ 35

4.2 Flutuação populacional dos vetores....................................... 40

4.3 Infectividade natural de cigarrinhas vetoras............................. 47 
Página

4.4 Flutuação populacional da bacteria na planta cítrica....................... 51

4.5 Efeito da época de inoculação na sobrevivência de $X$. fastidiosa em árvores cítricas.............................................................. 57

4.5.1 Inoculações mecânicas........................................... . 57

4.5.2 Inoculação por cigarrinhas vetoras................................... 61

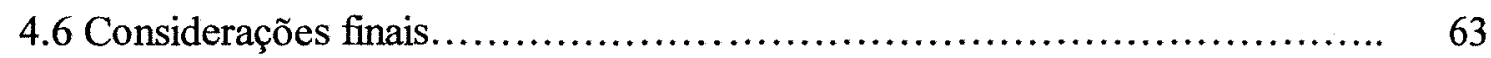

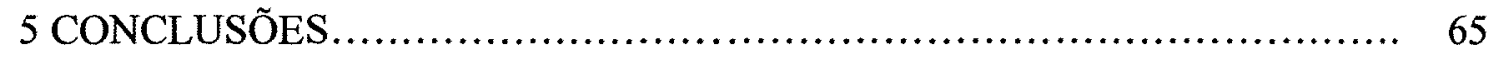

REFERÊNCIAS BIBLIOGRÁFICAS ...................................... 67 


\section{LISTA DE FIGURAS}

Página

1 Espécies de cigarrinhas identificadas como vetoras de $X$. fastidiosa em citros: (A) Acrogonia sp., (B) Oncometopia facialis, (C) Dilobopterus costalimai, (D) Ferrariana trivittata, (E) Homalodisca ignorata, (F) Bucephalogonia xanthophis, (G) Plesiommata corniculata, (H) Sonesimia grossa, (I) Macugonalia leucomelas e (J) Parathona gratiosa..

2 Cartão adesivo utilizado no monitoramento de cigarrinhas em pomares de laranja 'Pêra' localizados nos municípios paulistas de Neves Paulista, Gavião Peixoto e Santa Rita do Passa Quatro

3 Planta-isca utilizada no monitoramento de cigarrinhas em pomares de laranja 'Pêra' localizados nos municípios paulistas de Neves Paulista, Gavião Peixoto e Santa Rita do Passa Quatro

4 A) Flutuação populacional de adultos de cigarrinhas capturados por cartões adesivos amarelos em pomares de laranja 'Pêra', no município de Neves Paulista (SP), no período de agosto/1998 a julho/2000. B) Dados de precipitação pluviométrica e temperatura (médias) registrados para o período 
5 A) Flutuação populacional de adultos de cigarrinhas capturados por cartões adesivos amarelos em pomares de laranja 'Pêra', no município de Gavião Peixoto (SP), no período de agosto/1998 a julho/2000. B) Dados de precipitação pluviométrica e temperatura (médias) registrados para o período.........................................................

6 A) Flutuação populacional de adultos de cigarrinhas capturados por cartões adesivos amarelos em pomares de laranja 'Pêra', no município de Santa Rita do Passa Quatro (SP), no período de agosto/1998 a julho/2000. B) Dados de precipitação pluviométrica e temperatura (médias) registrados para o período....................................

7 Infectividade natural de cigarrinhas vetoras capturadas por cartões adesivos e plantas-iscas em pomares de laranja 'Pêra', localizados nos muicípios paulistas de Neves Paulista, Gavião Peixoto e Santa Rita do Passa Quatro, no período de agosto/98 a setembro/00 ....................

8 Infectividade natural de cigarrinhas vetoras capturadas por cartões adesivos e plantas-iscas, em pomares de laranja 'Pêra', localizados nos municípios paulistas de Neves Paulista, Gavião Peixoto e Santa Rita do Passa Quatro, nas diferentes estações do ano, no período de agosto/98 a setembro/00

9 A) Flutuação populacional de $X$. fastidiosa em plantas de laranja 'Pêra', no município de Neves Paulista (SP), no período de março/1999 a agosto/2000. B) Dados de precipitação pluviométrica e temperatura (médias) registrados para o período 
Página

10 A) Flutuação populacional de $X$. fastidiosa em plantas de laranja 'Pêra' no município de Gavião Peixoto (SP), no período de março/1999 a agosto/2000. B) Dados de precipitação pluviométrica e temperatura (médias) registrados para o período...........................................

11 A) Flutuação populacional de $X$. fastidiosa em plantas de laranja 'Pêra', no município de Santa Rita do Passa Quatro (SP), no período de março/1999 a agosto/2000. B) Dados de precipitação pluviométrica e temperatura (médias) registrados para o periodo.......................... 


\section{LISTA DE TABELAS}

Página

1 Características de vegetação e manejo dos pomares de laranja estudados..

2 Número total de cigarrinhas capturadas pelos métodos de cartão adesivo amarelo e de planta-isca em pomares de laranja 'Pêra' localizados em três municípios paulistas, no biênio $1998 / 2000$

3 Comparação entre o número de indivíduos de cada espécie de cigarrinha capturados por cartões adesivos em pomares de laranja 'Pêra' de três regiões da citricultura paulista, no período de agosto/1998 a julho/2000...

4 Comparação entre o número de indivíduos de cada espécie de cigarrinha capturados por plantas-iscas em pomares de laranja 'Pêra' de três regiões da citricultura paulista, no período de agosto/1998 a julho/2000 ...........

5 Análise de regressão das espécies de cigarrinhas Acrogonia sp. e $D$. costalimai capturadas em cartões adesivos, em pomares de laranja 'Pêra', localizados em três municípios paulistas, considerando as variáveis climáticas, temperatura média e precipitação, de cada região estudada.....

6 Infectividade natural de cigarrinhas vetoras capturadas por cartões adesivos e plantas iscas em três pomares do Estado de São Paulo, no período de agosto/98 a setembro/00 
Página

7 População de células viáveis de $X$. fstidiosa em folhas sintomáticas de árvores de laranja 'Pêra' com sintomas de CVC em diferentes áreas do Estado de São Paulo, no período de fevereiro/1999 a junho/1999..........

8 Avaliação do sucesso de infecção por $X$. fastidiosa em sucessivos períodos após a inoculação mecânica de ramos de laranja 'Pêra' nos municípios de Neves Paulista e Santa Rita do Passa Quatro..................

9 Avaliação do sucesso de infecção por $X$. fastidiosa após 5 meses da inoculação mecânica ${ }^{\mathrm{a}}$ de ramos cítricos de laranja 'Pêra', no município de Neves Paulista (SP) ............................................

10 Avaliação do sucesso de infecção por $X$. fastidiosa após 5 meses da inoculação mecânica ${ }^{a}$ de ramos cítricos de laranja 'Pêra', no município de

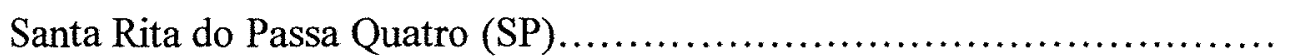

11 Avaliação do sucesso de inoculação de $X$. fastidiosa por cigarrinhas infectivas $^{\mathrm{a}}$ no pomar de laranja 'Pêra' localizado no município paulista de Gavião Peixoto, em quatro diferentes épocas........................... 


\title{
ESTUDO DE FATORES SAZONAIS RELACIONADOS À TRANSMISSÃO DE Xylella fastidiosa EM POMARES DE CITROS
}

\author{
Autora: Érica Frazão Pereira \\ Orientador: João Roberto Spotti Lopes
}

\section{RESUMO}

A Clorose Variegada dos Citros (CVC) é uma das doenças mais importantes na citricultura brasileira, atualmente. A doença é causada por uma bactéria gram-negativa, denominada Xylella fastidiosa, transmitida por várias espécies de cigarrinhas da subfamília Cicadellinae (Hemíptera, Cicadellidae). Visando-se identificar épocas de maior probabilidade de disseminação da CVC, três pomares de laranja doce (Citrus sinensis), localizados nas regiões noroeste (Neves Paulista), central (Gavião Peixoto) e sul (Santa Rita do Passa Quatro) do Estado de São Paulo, foram estudados com o objetivo de se analisar aspectos sazonais que possam influenciar a transmissão de $X$. fastidiosa por vetores em citros. Através de monitoramentos periódicos dos principais vetores, verificou-se que os cartões adesivos amarelos capturaram 6,3 vezes mais cigarrinhas que armadilhas constituídas de mudas cítricas cobertas com substância pegajosa (plantas-iscas). A espécie vetora Dilobopterus costalimai predominou no pomar da região sul, enquanto que a espécie Acrogonia sp. foi capturada em maior quantidade nos pomares das regiões noroeste e central. Verificou-se diferença estatística significativa no número total de indivíduos das espécies Acrogonia sp., Bucephalogonia xanthophis, D. costalimai e Oncometopia facialis, capturadas por cartões adesivos, entre os pomares estudados. Já para as plantas-iscas, somente $D$. costalimai e Ferrariana trivittata apresentaram diferença estatística significativa. A taxa de infectividade natural dos vetores capturados, avaliada por DAS-ELISA com antissoros policlonais para $X$ fastidiosa, foi de $4,2 \%$, em média, não havendo diferença estatística significativa entre as estações do ano. Dentre as espécies de cigarrinhas capturadas em maior quantidade, Acrogonia sp., B. xanthophis e D. costalimai, 
apresentaram infectividade natural de $6,3 \%, 2,6 \%$ e 4,8\%, respectivamente. A concentração de células viáveis da bactéria $X$. fastidiosa em folhas sintomáticas foi avaliada mensalmente através de isolamento em meio de cultura sólido. No isolamento primário a partir de trituração de amostras foliares em tampão fosfato (PBS), utilizou-se uma diluição de $10 \mathrm{X}$ da suspensão antes do plaqueamento; este procedimento permitiu redução do percentual de contaminação e eficiência de isolamento de $X$. fastidiosa superior a $70 \%$. A população média de células cultiváveis de $X$. fastidiosa, em nervuras centrais de folhas sintomáticas de citros, foi de 5,76 $\pm 0,07 \log \mathrm{UFC} / \mathrm{g} / \mathrm{mL}$, sem diferença estatística significativa entre os pomares estudados. Em diferentes épocas do ano, foram realizadas inoculações em ramos sadios de 15 árvores cítricas, nos pomares das regiões noroeste e sul, sendo 4 ramos por árvore. Os ramos foram podados após cinco meses e avaliados por cultura e DAS-ELISA indireto. Diferenças estatisticamente significativas foram obtidas no número de ramos positivos para diferentes épocas de inoculação, com tendência de maior recuperação de células viáveis de $X$. fastidiosa nas inoculações realizadas nos meses de dezembro e fevereiro. Cigarrinhas submetidas à alimentação em plantas-fonte de $X$. fastidiosa foram colocadas para alimentação em ramos cítricos sadios no pomar da região central, em diferentes épocas do ano, obtendo-se baixa eficiência de transmissão, correspondendo a $6,5 \%$ do total de ramos inoculados. Os dados obtidos sugerem que o período de maior disseminação da doença ocorre quando a temperatura anual média começa a se elevar e as chuvas tornam-se mais freqüentes (a partir de outubro ou novembro), pois nessa época o inóculo bacteriano continua presente no xilema de citros, para aquisição pelos vetores, e a sobrevivência de $X$. fastidiosa em infecções iniciais tende a ser mais elevada. 


\title{
STUDY OF SEASONAL FACTORS RELATED TO THE TRANSMISSION OF Xylella fastidiosa IN CITRIC ORCHARDS
}

\author{
Author: ÉRICA FRAZÃO PEREIRA \\ Adviser: JOÃO ROBERTO SPOTTI LOPES
}

\section{SUMMARY}

Variegated Chlorosis of Citrus (CVC) it is one of the most important diseases in the Brazilian citriculture. The disease is caused by a bacterium gram-negative, denominated Xylella fastidiosa, transmitted by several species of leafhoppers of the subfamily Cicadellinae (Hemíptera, Cicadellidae). Being sought to identify times of larger probability of spread of CVC, three orchards of sweet orange (Citrus sinensis), located in the regions northwest (Neves Paulista), central (Gavião Peixoto) and south (Santa Rita of the Raisin Four) of São Paulo State, they were studied with the objective of analyzing seasonal aspects that can influence the transmission of $X$. fastidiosa by vectors in citrus. Through periodic monitoring of the main vectors, it was verified that the stickers yellow cards captured 6,3 times more leafhoppers than constituted traps of citric seedlings covered with sticky substance (plant-baits). The vector species Dilobopterus costalimai prevailed at the orchard of the south region, while the specie Acrogonia sp. it was captured in larger quantity in the orchards of the regions northwest and central. It was verified differentiates significant statistics in the total number of individuals of the species Acrogonia sp., Bucephalogonia xanthophis, D. costalimai and Oncometopia facialis, captured by adhesive cards, among the studied orchards. Already for the plant-baits, only D. costalimai and Ferrariana trivittata presented significant statistical difference. The tax of natural infectivity of the vector ones captured, evaluated for DAS-ELISA with polyclonal antibodies for X.fastidiosa, it was of $4,2 \%$, on average, not having difference significant statistics among the seasons. Among the species of leafhoppers captured in larger quantity, Acrogonia sp., B. xanthophis and D. costalimai, 
presented natural infectivity of $6,3 \%, 2,6 \%$ and $4,8 \%$, respectively. The concentration of viable cells of the bacterium $X$. fastidiosa in symptomatic leaves was evaluated monthly through isolation in solid middle of culture. In the primary isolation starting from grinding of samples foliate in buffer phosphate (PBS), a dilution of $10 \mathrm{X}$ of the suspension was used before the plating; this procedure allowed reduction of the percentile of contamination and isolation efficiency of superior $X$. fastidiosa to $70 \%$. The medium population of arable cells of $X$. fastidiosa, in central veins of symptomatic leaves of citrus, was of $5,76 \pm 0,07 \log \mathrm{UFC} / \mathrm{g} / \mathrm{mL}$, without significant statistical difference among the studied orchards. In different times of the year, inoculations were accomplished in healthy branches of 15 citric trees, in the orchards of the regions northwest and south, being 4 branches for tree. The branches were pruned after five months and evaluated for culture and DAS-ELISA indirect. Significant statistics differences were obtained in the number of positive branches for different inoculation times, with tendency of larger recovery of viable cells of $X$. fastidiosa in the inoculations accomplished the months of December and February. Leafhoppers submitted to the feeding in plant-source of $X$. fastidiosa were put for feeding in healthy citric branches in the orchard of the central region, in different times of the year, being obtained lowers transmission efficiency, corresponding to $6,5 \%$ of the total of inoculated branches. The obtained data suggest that the period of larger spread of the disease happens when the medium annual temperature begins rising and the rains become more frequent (starting from October or November), because in that time the bacterial inoculum continues present in the citrus xylem, for acquisition for the vector ones, and the survival of $X$. fastidiosa in initial infections tends to be higher. 


\section{INTRODUÇÃO}

Dentre as diversas doenças que afetam a citricultura brasileira, a Clorose Variegada dos Citros (CVC) é um dos principais problemas atualmente, preocupando citricultores, indústria citrícola, técnicos e pesquisadores (Paiva et al, 1996). Esta doença afeta todas as variedades comerciais de laranja doce [Citrus sinensis (L.) Osbeck], reduzindo drasticamente o tamanho dos frutos, que se tornam pequenos e duros, com alto teor de açúcar e imprestáveis para a indústria e consumo in natura (Lee et al., 1993). Em ordem decrescente, as cultivares mais afetadas são: Pêra, Natal, Valência e Hamlin. As plantas cítricas podem ser afetadas desde o viveiro até 10 anos de idade (Carvalho, 1996), porém, dentro desse período, as faixas etárias mais suscetíveis são de 3 a 4 anos (Ayres, 2000). A CVC não foi observada em pomares de limas ácidas, limões verdadeiros e de tangerinas (Malavolta et al., 1993).

A CVC é causada por uma bactéria endofitica, gram-negativa, limitada ao xilema e identificada como Xylella fastidiosa Wells et al., que pode ser transmitida a partir de mudas e borbulhas infectadas (Sempionato et al., 1997) e por várias espécies de cigarrinhas pertencentes à familia Cicadellidae, subfamília Cicadellinae (Roberto et al., 1996; Krügner et al., 1998). Vetores da familia Cercopidae também são conhecidos, porém para outras estirpes de X. fastidiosa (Turner \& Pollard, 1959; Frazier, 1965; Purcell, 1989).

Considerando-se a importância da laranja doce para a indústria citrícola e a inexistência de variedades de laranja doce resistentes à $\mathrm{CVC}$, torna-se imprescindível o desenvolvimento de tecnologia para convivência com o problema. Várias medidas de convivência com a doença têm sido indicadas para o manejo da CVC, tais como: a) instalação de pomares com mudas sadias; b) redução do inóculo em pomares infectados 
através da poda de ramos com sintomas iniciais e/ou eliminação de plantas com infecção sistêmica generalizada; e c) controle químico dos vetores (De Negri \& Garcia Júnior, 1993). O controle químico das cigarrinhas tem sido amplamente utilizado em viveiros e pomares cítricos. Entretanto, devido à grande diversidade de potenciais vetores presentes em citros em vários períodos do ano (Paiva et al., 1996; Yamamoto, 1998), essa prática tem demandado pulverizações freqüentes com produtos pouco seletivos, em áreas extensas, o que pode causar desequilíbrio biológico e pôr em risco o manejo integrado de pragas dos citros.

O manejo racional dos vetores visando ao controle da CVC ainda depende de algumas informações básicas, tais como a identificação das espécies vetoras chaves para a disseminação da doença e a determinação da época crítica de transmissão da bactéria e infecção de plantas cítricas (Lopes, 1999). Esses conhecimentos permitiriam definir quais espécies de cigarrinhas devem ser consideradas no manejo, e qual(is) a(s) época(s) mais apropriada(s) para a controle destes insetos. Entre as espécies que transmitem $X$. fastidiosa em citros, as cigarrinhas Acrogonia sp., Bucephalogonia xanthophis (Berg), Dilobopterus costalimai (Young) e Oncometopia facialis (Signoret) têm grande importância por serem predominantes em plantas cítricas em viveiros ou pomares (Paiva et al., 1996; Yamamoto, 1998). A determinação da(s) época(s) de maior probabilidade de transmissão de $X$. fastidiosa depende ainda do estudo de alguns aspectos, tais como a época de ocorrência desses vetores e possiveis variações sazonais na infectividade natural das cigarrinhas, no inóculo do patógeno em árvores cítricas e na suscetibilidade de citros à infecção por X. fastidiosa (Lopes, 1999).

Esta pesquisa teve por objetivo analisar fatores sazonais que podem influenciar a transmissão de $X$. fastidiosa por vetores em citros, visando-se identificar épocas de maior probabilidade de disseminação da CVC, em que as medidas de controle devem ser reforçadas. Para tal, foram conduzidos monitoramentos periódicos do inóculo na planta (população de bactéria) e nos principais vetores (infectividade natural) em três áreas representativas da citricultura paulista, além do levantamento populacional destes vetores. Paralelamente, avaliou-se a sobrevivência e multiplicação de $X$. fastidiosa em ramos de árvores cítricas no campo, após sua inoculação em diferentes épocas do ano. 


\section{REVISÃO DE LITERATURA}

\subsection{Clorose variegada dos citros e seu agente causal}

A CVC atualmente é considerada uma das doenças de maior importância nos pomares cítricos do Brasil (Lima et al., 1996). Surgindo no ano de 1987, em municípios localizados nas regiões sul de Minas Gerais e norte do Estado de São Paulo (Rossetti et al., 1990), teve rápida disseminação nas regiões citrícolas de praticamente todo o território nacional (Rossetti et al., 1990; Tubelis et al., 1993).

O Estado de São Paulo, como maior produtor brasileiro, vem sofrendo perdas anuais de produção e de árvores, estimadas ao redor de $R \$ 235$ milhões, incluindo o custo de manejo (CVC, 2000). No ano de 1996 a incidência da doença cresceu de 22,23\% para 35,52 \% em 1999 (Ayres, 2000). Já no ano 2000 a incidência mostrou-se menor, sugerindo uma estabilização da doença, apresentando 20,8\% das árvores com sintomas graves (nível 2), que atinge ramos e frutos (frutos pequenos), e 13,3\% com sintomas iniciais (nível 1), ocorrendo apenas em folhas (CVC, 2000). No cinturão citrícola paulista o problema é endêmico, e a incidência e severidade da doença não são uniformes entre as regiões. As regiões central e sul apresentam incidência e severidade inferiores às regiões norte e noroeste (Salva et al., 1995). Em 1999, as regiões norte e noroeste do Estado de São Paulo apresentaram as maiores incidências da doença, respectivamente com 55,38\% e 46,61\% (Ayres, 2000). No ano 2000, esse percentual foi de $52,6 \%$ e $43,4 \%$ (CVC, 2000), e as regiões citrícolas central e sul, passaram de 32,33\% e 23,23\% em 1999 (Ayres, 2000) para 28,7\% e 15,7\%, de plantas sintomáticas, respectivamente (CVC, 2000). A doença vem sendo associada ao estresse hídrico e 
temperaturas elevadas, sendo as regiões citrícolas situadas ao norte e centro do Estado de São Paulo mais afetadas que a região sul (Gravena et al., 1997).

Todas as cultivares de laranja doce são afetadas pela doença (Laranjeira et al., 1995), além de algumas tangerinas, tangores e uma laranja azeda que apresentaram sintomas (Pompeu Júnior et al, 1998; Laranjeira et al., 1998). Em pomares comerciais de limas, limões verdadeiros e pomelos, a doença ainda não foi observada (Malavolta et al., 1993; Rossetti et al., 1997). As árvores afetadas apresentam sintomas de clorose foliar, similares a deficiência de zinco. Folhas novas não mostram sintomas, porém as velhas, apresentam uma clorose variegada distinta. Na face abaxial das folhas surgem lesões de cor marrom-clara que correspondem às áreas cloróticas amarelas na face adaxial. As áreas cloróticas podem tornar-se marrom-escuras ou necróticas, chegando muitas vezes, a coalescer (Rossetti et al., 1990; Lee et al., 1993). Plantas severamente afetadas não morrem, mas apresentam uma atrofia e diminuição da copa, muitas vezes adquirindo um aspecto amarelado (Lee et al., 1993; Laranjeira, 1997). Pode ainda, ocorrer queda de folhas, morte de ponteiros, encurtamento de entrenós e aumento de brotações nas gemas dos ramos afetados (Laranjeira, 1997). Os frutos de árvores afetadas são pequenos e duros, apresentam alto conteúdo de açúcar, amadurecem precocemente e sua produção é reduzida (Rossetti et al., 1990; Lee et al., 1993; Huang \& Chiaradia, 1998). Esses frutos, por apresentarem baixa qualidade, não são aceitos pelo mercado de frutas frescas, nem pelas indústrias de processamento de suco (Huang \& Chiaradia, 1998).

\subsection{O agente causal da CVC}

Rossetti et al. (1990) relacionaram a CVC à presença de bactérias associadas ao xilema das plantas doentes. Através de microscopia eletrônica, esses autores verificaram que a morfologia dessas bactérias era semelhante à descrita para a bactéria causadora da doença de Pierce ("Pierce disease" - PD) em videiras, denominada Xylella fastidiosa.

$X$. fastidiosa é uma bactéria endofitica, gram-negativa e limitada ao xilema. Possui forma de bastonete, com 0,25 a $0,35 \mu \mathrm{m}$ de diâmetro por 0,9 a $3,5 \mu \mathrm{m}$ de comprimento (forma alongada) e parede celular enrugada. Estritamente aeróbica, 
apresenta crescimento ótimo entre 26 e $28^{\circ} \mathrm{C}$ e em pH entre 6,5 a 6,9 , além de conteúdo $\mathrm{G}+\mathrm{C}$ (guanina + citosina) de 51 a $53 \mathrm{~mol} \%$ (Wells et al., 1987).

Após a associação do patógeno com a $X$. fastidiosa por microscopia (Rossetti et al., 1990; Chagas et al., 1992), materiais de árvores afetadas foram estudados e a bactéria foi detectada por isolamento em meio de cultura BCYE (Leite Júnior \& Leite, 1991) e testes sorológicos como "Dot Immunobinding Assay" (DIBA) utilizando-se um anticorpo policlonal para $X$. fastidiosa (Lee et al., 1992). Passados três anos de estudo, o Postulado de Koch foi finalmente concluído, sendo designada a bactéria $X$. fastidiosa como o verdadeiro agente causal da CVC (Lee et al., 1993; Chang et al., 1993).

Além das culturas de citros e videira, a $X$. fastidiosa foi detectada em várias espécies de plantas arbóreas, perenes e herbáceas, podendo ou não manifestar sintomas (Hopkins \& Adlerz, 1988; Hopkins, 1989). Dentre as espécies de importância econômica, causa doenças em pessegueiro, ameixeira, amendoeira, alfafa, pereira, carvalho, cafeeiro dentre outras (Hopkins, 1989; Purcell, 1994; Hill \& Purcell, 1995; Purcell, 1997; Purcell \& Saunders, 1999). Quando patogênica, a bactéria pode bloquear o movimento de água e translocação de seiva no interior do xilema (Gravena et al., 1997), porém, apresenta-se distribuída de foram irregular nesses vasos (Hill \& Purcell, 1995).

No Brasil, além da CVC, são relatadas duas outras doenças causadas por $X$. fastidiosa, a escaldadura das folhas da ameixeira (Kitajima et al., 1975) e a requeima das folhas do cafeeiro (Paradela et al., 1995), cujos impactos ainda estão sendo estudados. Nos últimos anos, a bactéria foi relatada em países fora do continente americano, causando escaldadura da folha em pereiras em Taiwan (Leu \& Su, 1993) e PD em videira na Iugoslávia (Berisha et al., 1998).

\subsection{Deteç̧ão de $X$. fastidiosa e diagnose da CVC}

Vários testes vêm sendo utilizados para a detecção de $X$ fastidiosa de plantas e de vetores, como "Enzime Linked Immunosorbent Assay" (ELISA) (Nomé et al., 1980; Raju et al., 1983; Sherald \& Lei, 1991), "Polimerase Chain Reaction" (PCR) 
(Minsavage et al., 1983; Pooler \& Hartung, 1995), isolamento em meio de cultura (Davis et al., 1980; Wells et al., 1981; Lee et al., 1983; Leite Júnior \& Leite, 1991; Hill \& Purcell, 1995), microscopia (Rossetti et al, 1990;), DIBA (Lee et al., 1992), Imunocaptura magnética (Pooler et al., 1997), dentre outros.

Hopkins \& Adlerz (1988) utilizaram os testes de microscopia de fluorescência, ELISA e isolamento em meio de cultura para determinar a infecção natural de várias plantas arbóreas e invasoras com $X$. fastidiosa a fim de relacionar os hospedeiros alternativos da bactéria na Flórida. O teste ELISA foi mais eficiente que a microscopia de fluorescência, e o meio de cultura PW apresentou respostas semelhantes ao teste ELISA na detecção da bactéria, porém, alguns hospedeiros apresentaram-se negativos no isolamento em meio PD3. Com isso, as estirpes de $X$. fastidiosa de videira foram separadas em dois grupos, aquelas que crescem nos dois meios, e aquelas que crescem somente em meio PW.

Um kit prático e confiável de ELISA foi elaborado por Sherald \& Lei (1991) visando facilitar a detecção da bactéria $X$. fastidiosa de árvores. O teste mostrou-se efetivo na detecção da bactéria de extratos de elm (Ulmus americana), plátano (Platanus ocidentalis), carvalho vermelho (Quercus rubra), red maple (Acer rubrum) e amora vermelha (Morus rubra) com sintomas de escaldadura das folhas, e foi indicado para a distinção de hospedeiros alternativos da bactéria.

Visando determinar a associação entre CVC e a presença da bactéria, além de servir como um teste auxiliar em estudos de transmissão e epidemiologia, Lee et al. (1992) desenvolveram um antissoro específico de $X$. fastidiosa para ser utilizado em testes de DIBA. O teste mostrou-se mais sensível na deteç̧ão de $X$. fastidiosa de plantas afetadas que o teste ELISA, foi de rápida execução, e exigiu menos equipamentos.

Minsavage et al. (1994) desenvolveram um protocolo de Polymerase Chain Reaction (PCR) para deteç̧ão de $X$. fastidiosa de tecidos de plantas a partir de um fragmento de DNA genômico conservado. O PCR mostrou-se 100 vezes mais sensível que o teste de ELISA, atingindo limites de detecção de $1 \times 10^{2} \mathrm{UFC} / \mathrm{mL}$, enquanto o teste de ELISA atingiu um limiar de $2 \times 10^{4} \mathrm{UFC} / \mathrm{mL}$. "Primers" específicos para amplificação da bactéria de tecidos de plantas (272-1 e 272-2), foram desenvolvidos por 
Pooler \& Hartung (1995). Pooler et al. (1997) detectaram X. fastidiosa de insetos vetores, utilizando a metodologia previamente desenvolvida, associada à imunocaptura magnética, que aumentou a sensibilidade do teste.

Os métodos serológicos de diagnóstico da bactéria mais utilizados são o DIBA e o ELISA, porém esses, apresentam reações inespecíficas e baixa sensibilidade, podendo não detectar o patógeno em estádios iniciais. Já os testes de PCR providenciam um diagnóstico rápido e seguro, podendo detectar cerca de 102 bactérias $/ \mathrm{mL}$ (Coletta Filho et al., 1996). De acordo com Beretta (1997), os testes sorológicos desenvolvidos para a detecção da bactéria (DIBA, ELISA e "Western blotting") têm-se mostrado eficientes para uma rápida deteç̧ão, mas são limitantes para o uso de diferenciação de estirpes. $\mathrm{A}$ identificação de estirpes de $X$. fastidiosa era limitada a métodos biológicos, utilizando plantas indicadoras através de transmissão por cigarrinhas ou por cultura da bactéria e inoculação mecânica. Foi desenvolvido um procedimento para detectar a maioria das estirpes de $X$. fastidiosa, usando "primers" da região genômica do DNA, a qual se mostrou conservada em 18 estirpes (Beretta, 1997). Além disso, através de uma seleção com marcador de RAPD, foram desenvolvidos "primers" específicos para a estirpe CVC. A técnica de PCR utilizando "primers" da região consensual do RNAt gerou seqüências de oligonucleotídeos que se mostraram específicas para as estirpes da CVC (Beretta, 1997). Técnicas baseadas em PCR estão sendo freqüentemente utilizadas no Brasil para determinar se outras estirpes, além da responsável pela CVC, estão presentes e se existem outros hospedeiros para sua estirpe (Beretta, 1997).

Testes de isolamento em meio de cultura, além de auxiliarem na diferenciação de estirpes, possibilitam determinar o número de células bacterianas viáveis por grama de tecido de plantas. Hill \& Purcell $(1995 ;$ 1997) utilizaram o meio de cultura PWG, modificado do meio PW, no qual foram utilizados $9 \mathrm{~g}$ de Gelrite no lugar de ágar e 15 $\mathrm{mL}$ de soro albumina bovina (BSA) ao invés de $30 \mathrm{~mL}$. As amostras de tecidos de plantas ou de insetos foram esterilizadas superficialmente e trituradas em tampão fosfato salino (PBS) estéril, utilizando um homogeneizador. Em seguida, foram diluídas 10 vezes e duas gotas foram plaqueadas. O limite de deteç̧ão do teste foi de 100 células de $X$. fastidiosa cultiváveis/g de tecido/amostra e para ELISA, esse limite foi de $10^{5}$ células 
bacterianas/grama de tecido de planta. Almeida (1999) utilizou a metodologia de isolamento bacteriano, descrita por Hill \& Purcell (1995), e constatou sua eficiência no isolamento e quantificação de $X$. fastidiosa para plantas de citros em meio de cultura. Três meios de cultura utilizados para o isolamento primário de $X$. fastidiosa foram testados por Almeida (1999), PW, PWG e BCYE. Os dois primeiros mostraram-se mais adequados para o isolamento da estirpe de citros, promovendo um crescimento mais rápido que em meio $\mathrm{BCYE}$.

Os valores obtidos na quantificação de $X$. fastidiosa de tecidos de plantas com CVC atingem populações entre $10^{3}$ a $10^{6}$ unidades formadoras de colônia (UFC)/g de tecido (Almeida, 1999), mostrando-se bem inferiores aos valores obtidos para a estirpe de videira que chegam a atingir $10^{9} \mathrm{UFC} / \mathrm{g}$ pelo mesmo método de isolamento (Hill \& Purcell, 1995).

\subsection{Transmissão de $X$. fastidiosa}

\subsubsection{Grupos de vetores e mecanismos de transmissão}

Estudos com várias estirpes de $X$. fastidiosa comprovaram que os vetores são cigarrinhas que se alimentam no xilema de plantas infectadas, pertencentes às famílias Cicadellidae (subfamilia Cicadellinae) e Cercopidae (Turner \& Pollard, 1959; Frazier, 1965; Purcell, 1989). Essas cigarrinhas são insetos sugadores que se alimentam de uma vasta gama de plantas hospedeiras (Purcell, 1989; Hopkins, 1991). A maioria dos trabalhos está relacionada às estirpes associadas a PD em videira e à doença de "phony" em pessegueiro ("phony peach disease" - PPD) (Purcell, 1989).

A transmissão por vetores pode ser dividida nas seguintes fases seqüenciais: aquisição, latência e inoculação (Gravena et al., 1998). O período de acesso à aquisição (PAA) é definido como o período que um vetor não infectado tem acesso a uma fonte de inóculo para a aquisição de um agente infeccioso. O período latente é o tempo requerido entre a aquisição de um patógeno pelo vetor e a sua transmissão para a planta. Uma vez adquirida a bactéria, as cigarrinhas podem transmiti-la para as plantas durante 
praticamente toda a vida (Severin, 1949). Apenas nas fases ninfais ocorre perda da capacidade de transmissão da bactéria, devido às ecdises (Purcell \& Finlay, 1979), quando ocorrem as trocas das cutículas do aparelho bucal, e tubo digestivo anterior (estomodéu), que aloja a bactéria (Purcell, 1994).

No caso da transmissão por Graphocephala atropunctata (Signoret) em videiras, verificou-se que as cigarrinhas podem adquirir essa bactéria em apenas uma hora de alimentação em uma planta infectada, e podem transmiti-la para as plantas sadias imediatamente após a aquisição. Dessa forma observa-se que não existe período latente perceptível e que a bactéria não circula no vetor (Purcell \& Finlay, 1979). Aparentemente a aquisição de $X$. fastidiosa por cigarrinhas ocorre somente mediante alimentação dos indivíduos em plantas infectadas, não tendo sido verificada a passagem da bactéria por transmissão transovariana (Freitag, 1951).

As cigarrinhas da familia Cicadellidae são reconhecidamente as mais importantes vetoras de $X$ fastidiosa, possuindo representantes relativamente grandes e de cabeça proeminente, com uma musculatura desenvolvida para succionar o conteúdo dos vasos xilemáticos, que funcionam sob pressão negativa (Purcell, 1979; 1989). A capacidade de sucção de seiva é um dos primeiros requisitos para que um inseto possa transmitir a bactéria (Purcell \& Hopkins, 1996). Além disso, as cigarrinhas devem possuir uma câmara filtro bastante evoluída, que lhes permita succionar uma grande quantidade de líquidos, sob forte pressão negativa, e com alta eficiência de assimilação de nutrientes, já que a seiva do xilema apresenta baixa concentração de aminoácidos (Purcell, 1989; Andersen et al., 1992).

Segundo Purcell (1989), não são apenas as cigarrinhas pertencentes à Cicadellinae e Cercopidae que apresentam a capacidade de contatar e ingerir líquidos do xilema, pois existem Cicadelídeos pertencentes a subfamílias distintas de Cicadellinae, que freqüentemente ingerem líquidos do xilema durante picadas de prova, embora não sejam especialistas nesse local de alimentação. Porém, tentativas de transmissão de $X$. fastidiosa por tais grupos de Cicadelídeos alcançaram resultados negativos (Purcell, 1980; Severin, 1949). Como ocorre transmissão de X. fastidiosa por cigarrinhas de famílias distintas, a competência de um vetor está mais relacionada com o hábito 
alimentar do que com relações filogenéticas com outras espécies de vetores (Purcell, 1989).

\subsubsection{Transmissão de $X$. fastidiosa em citros}

A transmissão de $X$. fastidiosa em citros pode ocorrer através de mudas e borbulhas contaminadas (Lima et al., 1996; Sempionato et al., 1997) e por insetos vetores (Purcell, 1979). Várias espécies de cigarrinhas sugadoras de seiva do xilema (Cicadellinae e Cercopidae), apresentam potencial para transmitir $X$. fastidiosa, podendo ocorrer em plantas cítricas em viveiros e no campo, na vegetação espontânea dos pomares ou áreas adjacentes à esses (Gravena et al., 1997; Paiva et al., 1996; Yamamoto, 1998).

A transmissão por vetores foi demonstrada inicialmente para as cigarrinhas Acrogonia sp., Dilobopterus costalimai (Young) e Oncometopia facialis (Signoret) (Lopes et al., 1996; Roberto et al., 1996). Posteriormente, outras oito espécies de Cicadelíneos foram relatadas como vetoras: Bucephalogonia xanthophis (Berg) e Plesiommata corniculata (Young) por Krügner et al. (1998), Acrogonia virescens, Ferrariana trivittata (Signoret), Homalodisca ignorata, Macugonalia leucomelas (Walker), Parathona gratiosa e Sonesimia grossa (Signoret) (Descobertos, 2000).

Krügner et al. (1998) avaliaram a eficiência de transmissão de $X$. fastidiosa por cinco espécies de cigarrinhas de ocorrência comum em pomares de citros: Acrogonia sp., B. xanthophis, D. costalimai, $O$. facialis e $P$. corniculata. Esses autores verificaram que a eficiência de transmissão de $X$. fastidiosa para citros é baixa, sendo esta de 1,3, 2,3, 2,9, 5,5 e 11,7\%, respectivamente, para $O$. facialis, Acrogonia sp., $P$. corniculata, D. costalimai e B. xanthophis, respectivamente. Esses resultados indicam que cigarrinhas de citros da tribo Cicadellini ( $B$. xanthophis e D. costalimai) são vetores mais eficientes que as da tribo Proconiini (Acrogonia sp. e $O$. facialis). De acordo com Paiva et al. (1996), a espécie de cigarrinha B. xanthophis pode ser capturada tanto em plantas cítricas quanto na vegetação espontânea dos pomares. Roberto et al. (2000) observaram que essa cigarrinha ocorre abundantemente em viveiros de mudas cítricas da 
região central do Estado de São Paulo, mesmo sob regimes de pulverizações sistemáticas de inseticidas.

De acordo com Day et al. (1952), vários fatores devem ser considerados para que um vetor seja considerado eficiente na aquisição ou inoculação de $X$. fastidiosa: a) freqüência com que o inseto atinge o xilema em diferentes espécies de plantas; b) tempo despendido e o modo de alimentação nos tecidos suscetíveis, e c) local de alimentação na planta (galhos, ramos ou folhas). Hill \& Purcell (1995) determinaram que com o aumento do tempo após a aquisição de $X$. fastidiosa por $G$. atropunctata, vetora da estirpe que causa PD em videiras, houve um aumento na eficiência de transmissão de 56 para $92 \%$ entre 1 hora e 7 dias após a aquisição. Verificou-se que a eficiência de transmissão se mantém alta posteriormente, em níveis de $91 \%$ e $76 \%$ a 21 e 60 dias após a aquisição, respectivamente. A eficiência desse vetor na Califórnia, é superior a $90 \%$, após um período de acesso à inoculação (PAI) de apenas 3 horas (Purcell \& Finlay, 1979).

A eficiência de transmissão de $X$. fastidiosa pelas cigarrinhas vetoras em citros é baixa quando comparada em videira por G. atropunctata nos Estados Unidos. Uma hipótese levantada para explicar tal fato é de que ocorre uma baixa eficiência de aquisição e/ou inoculação da bactéria pelos vetores, associada a um baixo percentual de sobrevivência do patógeno em infecções iniciais (Hill \& Purcell, 1995; Lopes, 1999). Em alguns hospedeiros alternativos da bactéria $X$. fastidiosa, tais como amieiro, freixo, negundo, urtiga e sabugueiro, a bactéria sobrevive por apenas algumas semanas. Porém, para a maioria das espécies, a multiplicação bacteriana apenas é detectada após 3 a 4 semanas, indicando que com o passar do tempo, as chances de cultivo de $X$. fastidiosa são maiores. Experimentos em casa de vegetação demonstraram que nesse ambiente, 3 a 4 semanas é um período razoável para a incubação da bactéria (Purcell \& Saunders, 1999). Alguns hospedeiros, como coffeeberry (Rhamnus californica) podem inibir o isolamento primário da bactéria, mas esse fato, não previne a multiplicação dentro das plantas, podendo ser adquiridas pelos vetores (Purcell \& Saunders, 1999). 
De acordo com estudos de Hill \& Purcell (1995), a maioria das plantas hospedeiras da estirpe que causa PD suporta pequenas populações de bactéria quando comparadas com videiras e outras plantas hospedeiras patológicas.

Hill \& Purcell (1997) verificaram uma relação positiva entre população de $X$. fastidiosa em videira e a transmissão por G. atropunctata, que é um vetor eficiente. As primeiras aquisições e subseqüentes inoculações ocorreram depois que a bactéria se multiplicou a uma população de $10^{4} \mathrm{UFC} / \mathrm{g}$ de tecido na planta-fonte. Altas populações de bactéria na planta resultaram em taxas mais elevadas de transmissão. A taxa de transmissão aumentou com o passar do tempo após a infecção da planta-fonte (de 4,5\% nos primeiros 10 dias para $55 \%$, depois de 25 dias) e com o aumento na população de células bacterianas viáveis recuperadas por cultura (de $5 \times 10^{5} \mathrm{UFC} / \mathrm{g}$, durante os primeiros 10 dias para $5 \times 10^{8}$, depois de 25 dias).

\subsection{Dinâmica populacional dos vetores de $X$. fastidiosa em citros}

"A flutuação populacional, dentro do estudo de populações de insetos, visa determinar a abundância de uma população em determinada área em um espaço de tempo. Sabe-se que o número de indivíduos de qualquer população está na dependência de fatores do meio ambiente, e quando os fatores favoráveis sobrepujam os desfavoráveis, a população aumenta" (Silveira Neto et al., 1976).

Conhecer o comportamento da população de cigarrinhas em pomares cítricos, ao longo do ano, é essencial para a adoção de estratégias de manejo (Gravena et al., 1997). O monitoramento de cigarrinhas está sendo feito através de observação visual, uso de cartões adesivos amarelos (trocados periodicamente) e utilização de puçá (inserido cuidadosamente nas brotações e sacudido para que as cigarrinhas passem para a rede) (Gravena et al., 1997).

A observação de plantas cítricas no campo tem demonstrado que as cigarrinhas têm preferência pela face da planta que não recebe os raios solares. Roberto et al. (1996), determinaram através de armadilhas adesivas amarelas, que as cigarrinhas são capturadas em maior número na face norte de plantas mais velhas, não sendo constatada 
preferência de distribuição em plantas novas. As cigarrinhas também demonstram preferência por se alimentarem em brotações e nos ramos com fluxos novos de crescimento (Gravena et al., 1997).

As cigarrinhas podem transmitir a bactéria durante todos os estágios (Purcell, 1979), sendo o estágio adulto mais importante nesse processo. Os adultos são facilmente observados em plantas de citros, bem como ninfas e ovos, porém esses, com maior dificuldade (Gravena et al., 1997).

Dados preliminares na literatura (Garcia Júnior et al., 1997) indicam que o período de maior ocorrência de cigarrinhas vetoras de $X$. fastidiosa nos pomares cítricos de São José do Rio Preto está compreendido entre os meses de janeiro e julho.

Levantamentos mensais de cigarrinhas em pomares paulistas de laranja, empregando aspirador à vácuo, no período de três anos, amostraram mais de 70 espécies de cigarrinhas pertencentes à oito familias. Essas, foram encontradas se alimentando no mesofilo foliar, floema (maioria) e no xilema das plantas (20 espécies), cuja alimentação é mais especializada. As espécies de cigarrinhas presentes na vegetação rasteira dos pomares foram relacionadas como potenciais vetoras e foi constatado que a comunidade de cigarrinhas da subfamilia Cicadellinae em citros é menos diversificada. Os cicadelíneos presentes em citros foram divididos em dois grupos: os que ocorriam quase que exclusivamente em citros (Acrogonia sp., $D$. costalimai e $O$. facialis) e aqueles de maior ocorrência em plantas invasoras (B. xanthophis e $M$. leucomelas). Como o segundo grupo é composto por cigarrinhas que se alimentam tanto em plantas invasoras quanto em plantas cítricas, podem veicular o patógeno para dentro ou fora dos pomares (Paiva et al., 1996).

Em levantamentos de cigarrinhas em pomares cítricos do Norte de São Paulo, Yamamoto (1996), constatou a existência de mais de 100 espécies, sendo 20 consideradas vetores potenciais ( $13 \mathrm{da}$ tribo Cicadellini, 5 da tribo Proconiini e alguns Cercopídeos), porém, nem todas eram cigarrinhas dos citros. Dentre essas, destacaramse a $B$. xanthophis e $P$. corniculata.

Cartões adesivos amarelos, foram utilizados na amostragem das espécies Acrogonia sp., D. costaimai e $O$. facialis no período de dezembro de 1994 a abril de 
1997. A precipitação e o défict hídrico foram relacionados à flutuação populacional de cigarrinhas, tornando possível relacionar o atraso do período de desenvolvimento vegetativo das plantas com os períodos de estiagem anteriores, e conseqüente, atraso na colonização das cigarrinhas, evidenciando a existência de hospedeiros alternativos (Roberto \& Yamamoto, 1998).

Em anos com distribuição normal de chuvas, o início da colonização das cigarrinhas normalmente ocorre em meados da primavera. Desse período em diante, recomenda-se o controle com inseticidas se a população atingir níveis superiores a $10 \%$ de plantas com cigarrinhas, sem distinção das espécies e independente do número, devendo-se iniciar o controle (Roberto \& Yamamoto, 1999). Entretanto, recomenda-se a utilização dos inseticidas sistêmicos dirigidos ao tronco das plantas cítricas ou os granulados de solo, pelo seu maior período residual e maior seletividade aos inimigos naturais (Roberto \& Yamamoto, 1998; Gravena, 1998).

\subsection{Epidemiologia de doenças causadas por $X$. fastidiosa}

Laranjeira (1997) estudando a dinâmica espacial e temporal da CVC, verificou que existe diferença na taxa de progresso da CVC entre as estações do ano. As taxas médias da primavera e verão foram estatisticamente superiores às do outono e inverno, $\mathrm{e}$ pequenas linhas de plantio com agregação de plantas doentes, indicaram ausência de influência de passagem de máquinas na disseminação da doença. Além de observar agregação de plantas doentes, foi demonstrada uma tendência dessas se localizarem na bordadura dos talhões contaminados. Isso é um forte indício de que em pomar sadio, os vetores contaminam a área trazendo a bactéria de fora, e depois dentro do próprio pomar, já que o autor observou que o número de focos por 1000 plantas cresceu com o aumento da incidência da doença, até 30\% de plantas com sintomas, quando então, ocorreu coalescência de focos. Nelson (1995) verificou que o número de plantas sintomáticas tendeu a aumentar até quando a incidência se situou próxima a $25 \%$, quando então, foi observada coalescência, semelhante aos dados obtidos por Klein et al. 
(1999), sugerindo que a probabilidade de novas infecções aumenta com a distância de árvores previamente infectadas. Gottwald et al. (1993) em estudos de dinâmica espacial e temporal da CVC, em pomares do interior paulista, sugeriram que a esses fatores estão relacionados a vetores de limitada dispersão aérea. Porém, Martins et al. (2000) determinaram que os vetores infectivos executam vôos longos ao acaso, a procura de plantas de citros não estressadas e com brotações.

Durante o período de janeiro a julho, os sintomas de CVC nas folhas podem ser vistos facilmente, porém, de agosto a dezembro ficam mascarados pela queda das folhas doentes e pela presença de brotações novas (Carvalho \& Laranjeira, 1994; Fundecitrus, 1998). Os sintomas de clorose foliar e senescência precoce de frutos, tornam-se mais evidentes na ausência de chuvas, com o estresse hídrico das plantas, o que normalmente ocorre a partir do mês de fevereiro até setembro (De Negri \& Garcia Júnior, 1993; Oliveira et al., 1995). De acordo com Palazzo (1993), o efeito da CVC sobre o desenvolvimento dos frutos começa a se pronunciar a partir do mês de fevereiro, tornando-se cada vez mais acentuado até o final do período de colheita.

As plantas cítricas podem ser afetadas desde o viveiro até 10 anos de idade (Carvalho, 1996), porém, dentro desse período, as faixas etárias mais suscetíveis são de intermediárias (3 a 5 anos e 6 a 10 anos) (Ayres, 2000). Foi demonstrado que os sintomas de CVC somente aparecem após 11 meses da sobreenxertia de borbulhas sadias sobre plantas contaminadas (Carvalho et al., citados por Rossetti et al., 1997). Sintomas em plântulas de citros, utilizando cigarrinhas infectivas, aparecem 6 meses após a inoculação (Lopes et al., 1996).

Estirpes de $X$. fastidiosa de PD em videira possuem uma ampla gama de hospedeiros (Hopkins, 1989), esses, exercem um papel importante como fonte de inóculo da bactéria em vinhedos (Hill \& Purcell, 1995). Plantas localizadas em áreas próximas à fontes de água (matas ciliares), servem tanto com hospedeiras de vetores quanto reservatórios onde as cigarrinhas podem adquirir e transmitir a bactéria para as videiras (Raju et al, 1983). Várias espécies de plantas que ocorrem dentro ou próximas de pomares de citros com declínio ou vinhedos com PD foram identificadas como hospedeiras de $X$. fastidiosa por Hopkins \& Adlerz (1988). Purcell (1974) estudando a 
estirpe de PD, observou que a maior incidência da doença ocorre na bordadura do vinhedo, em faixas de aproximadamente 100 metros, vizinhas de áreas de mata ciliar. Considera-se que o inóculo primário de PD seja proveniente de fontes externas, ocorrendo quase sempre disseminação secundária dentro dos vinhedos (Adlerz \& Hopkins, 1979). Estudos realizados por Purcell (1975) utilizando cartões adesivos para o monitoramento de uma espécie de cigarrinha vetora de PD, determinaram que essa espécie tende a se concentrar em áreas de mata ciliar durante a primavera, e a migrar para o vinhedo durante o verão, ocorrendo um aumento de infectividade natural na população nessa época (Purcell, 1975).Foi comprovado por Hopkins \& Thompson, (1984) que cigarrinhas vetoras provenientes de hospedeiros alternativos não se tornam infectivas nos vinhedos até o início do verão, quando a quantidade de bactéria nas videiras é alta. Hill \& Purcell (1997) demonstraram que a taxa de transmissão por cigarrinhas vetoras aumenta quando a população bacteriana nas plantas também aumenta.

O papel das plantas daninhas não está bem definido no patossistema citros, porém, a bactéria já foi detectada em plantas invasoras de ocorrência comum nos pomares de citros, como assa-peixe, capim-carrapicho, grama-seda, guanxuma, dentre outras (Travensolo \& Leite Júnior, 1996). Estão sendo estudados alguns hábitat alternativos de cigarrinhas, através de observações visuais de praticamente 50 espécies de plantas em áreas adjacentes aos pomares de citros, devido seu resurgimento pouco tempo após a aplicação de inseticidas (Lopes \& Giustolin, 2000).

As bactérias limitadas ao xilema localizam-se em células ou tecidos específicos, entretanto, elas tendem a e se acumular em algumas partes das plantas. Isso freqüentemente varia com o hospedeiro e está relacionado ao tipo de sintoma expresso (Purcell \& Hopkins, 1996). Essas bactérias crescem no fluido do xilema, que contém baixas concentrações de compostos orgânicos (Raven , 1984). altas concentrações de glutamina e ácidos orgânicos são exigidas pela bactéria $X$. fastidiosa, para crescer em meio de cultura (Chang \& Donaldson, 1993). Esses são os principais compostos encontrados na seiva do xilema das plantas (Andersen \& Brodbeck, 1989a). 
Os sintomas em plantas parecem depender da taxa de colonização das plantas hospedeiras (Purcell \& Hopkins, 1996). Alguns estudos consideram que ocorram mudanças químicas no fluido do xilema em função da temperatura (Andersen \& Brodbeck, 1989b). Purcell (1977), levantou a hipótese de que o clima de inverno pode limitar a distribuição de PD no norte dos Estados Unidos, assim como para PPD, pois pode ocorrer morte do patógeno.

Menores índices de isolamento de $X$. fastidiosa em ameixeira têm sido obtidos na primavera, com aumento no outono (Chang \& Yonce, 1987), mais precisamente picos no mês de maio e menor recuperação no mês de novembro em uma variedade suscetível à escaldadura das folhas (Leite et al., 1997). A sazonalidade de estirpes da bactéria em videira foi observada por Hopkins \& Thompson (1984), não sendo detectada na primavera, atingindo picos no verão e permanecendo detectável até o outono. Verifica-se que o aumento da população bacteriana nos tecidos das plantas hospedeiras normalmente coincide com o aparecimento de sintomas da doença (Leite et al., 1997).

No momento em que as folhas de videira desenvolvem necrose marginal, a infestação e o entupimento dos vasos pela $X$ fastidiosa aproximam-se de seu máximo (Hopkins \& Thompson, 1984). Mudanças fisiológicas aparentemente promovem um aumento da população bacteriana em videiras, como o estresse resultante da manutenção dos frutos e o balanço hormonal nas videiras, que podem exercer papel no desenvolvimento de sintomas de PD (Hopkins \& Thompson, 1984).

A falta de virulência de estirpes de PD está relacionada à habilidade da bactéria se multiplicar e mover sistematicamente no interior de videiras suscetíveis (Hopkins, 1985). Estirpes virulentas chegam a alcançar populações de $10^{6}-10^{7}$ UFC nos pecíolos inoculados de videiras, estirpes avirulentas alcançam somente $10^{4}-10^{5}$ UFC por centímetro $\mathrm{e}$ as fracamente virulentas, multiplicaram-se $\mathrm{e}$ movem-se mais vagarosamente e eventualmente podem alcançar $10^{6}$ UFC por centímetro (Hopkins, 1985).

Cultivares de videira com folhagens mais velhas, na maioria das vezes, mostramse mais resistentes à exposição de cigarrinhas do que quando apresentavam folhagens mais jovens, produzindo infecções que se disseminaram muito menos rapidamente a 
partir do ponto de inoculação. Em alguns cultivares de videira, poucas infecções persistem durante o inverno (estação de dormência), sendo as inoculações efetuadas com cigarrinhas no período de abril a junho, mais persistentes em todas os cultivares que as inoculações feitas em julho ou início de agosto (Purcell, 1981).

O clima de inverno pode ser um fator limitante importante para a distribuição de PPD e PD, pois ambas as doenças requerem insetos vetores para sua disseminação e células bacterianas viáveis no xilema de árvores afetadas (Purcell, 1977).

O tempo de incubação requerido para a deteç̧ão da bactéria difere em cada espécies de planta hospedeira, bem como a concentração bacteriana e percentagem de infecção (Hill \& Purcell, 1995).

A importância das plantas hospedeiras como fonte de inóculo de $X$. fastidiosa, depende se a bactéria está disseminada sistematicamente. Desse modo, plantas que suportam o movimento sistemático podem preservar e expandir o inóculo durante períodos de baixa abundância de vetores (Purcell \& Hopkins, 1996).

Substâncias que aceleram a maturidade e senescência das plantas são suspeitas de favoreçerem a multiplicação bacteriana, considerando que substâncias que retardam podem prevenir ou reduzir a população de $X$. fastidiosa (Hopkins, 1985). Chang \& Yonce (1987) e Hopkins (1989) verificaram que a $X$. fastidiosa pode não se multiplicar ativamente em tecidos jovens.

Yonce \& Chang (1987) investigaram a ocorrência sazonal e a distribuição de $X$. fastidiosa em vetores e plantas nas quais eles se alimentam, a fim de estabelecer os períodos críticos de inoculações da bactéria e da transmissão da doença de "Phony" em pessegueiro, sendo verificada a presença da bactéria em Homalodisca coagulata e numerosos hospedeiros, pouco tempo depois que as cigarrinhas encontravam-se nos pomares.

Gravena et al. (1997) demonstraram que plantas com CVC mesmo em solos com boa fertilidade e ricos em potássio apresentam teores nutricionais menores quando comparados com plantas sadias.

Com o início do período das chuvas nos pomares cítricos do Estado de São Paulo, os sintomas de CVC diminuem, devido à disponibilidade de água no solo. 
Quando se associa irrigação e poda de ramos sintomáticos em pomares adultos sem sintomas graves, nota-se uma redução nos sintomas da doença e melhorias na vegetação e produção de frutos (Gravena et al., 1997).

Várias medidas preventivas e de convivência com a doença vem sendo recomendadas, como a instalação de pomares com mudas sadias, o controle de plantas daninhas, a poda de ramos sintomáticos em pomares adultos e erradicação de plantas sintomáticas com menos de dois anos de idade, a aplicação de inseticidas (preferencialmente sistêmicos) no tronco ou granulados de solo para controle de vetores e a pulverização sistemática de plantas em viveiros (De Negri \& Garcia Júnior, 1993; Carvalho, 1996; Gravena, 1998). 


\section{MATERIAL E MÉTODOS}

Os experimentos foram conduzidos em três pomares de laranjeiras localizados nas regiões citrícolas noroeste, central e sul do Estado de São Paulo, respectivamente nos municípios de Neves Paulista (Estância Lilian), Gavião Peixoto (Sítio Carioca) e Santa Rita do Passa Quatro (Sítio Taquaral). Essas áreas foram escolhidas de forma a representar as principais regiões produtoras de laranja do estado.

Em cada pomar foi selecionado um talhão com incidência de CVC $<20 \%$, constituído de plantas de laranja doce (Citrus sinensis) da variedade Pêra, sobre portaenxerto limoeiro Cravo, que possuíam entre 3 e 4 anos de idade no início do experimento. Informações sobre a vegetação em áreas adjacentes e aplicação de insumos e produtos fitossanitários nos pomares estão apresentadas na Tabela 1. Houve diferença no tamanho dos talhões selecionados, sendo estes constituídos por 695, 1109 e 1080 plantas, respectivamente, nos pomares de Neves Paulista, Gavião Peixoto e Santa Rita do Passa Quatro. A incidência inicial de CVC, de acordo com avaliação de sintomas realizada em agosto de 1998 , era de $21,9 \%, 7,7 \%$ e $2,2 \%$ para os talhões localizados em Neves Paulista, Gavião Peixoto e Santa Rita do Passa Quatro, respectivamente.

$\mathrm{O}$ manejo de plantas daninhas foi diferenciado nas três áreas estudadas. O pomar situado ao noroeste do estado foi roçado a cada dois meses, apresentando, nas entrelinhas, predominância de capim-carrapicho, picão-preto e corda-de-viola. No pomar da região central, foram feitas aplicações de herbicida duas vezes por ano. Nesse pomar, observou-se principalmente capim-carrapicho, picão-preto, capim-brachiária, capimamargoso e capim-massambará. A área situada ao sul foi roçada a cada dois ou três meses, apresentando predominância de capim-brachiária, carrapicho-de-carneiro, capimcarrapicho, mentrasto e corda-de-viola. 


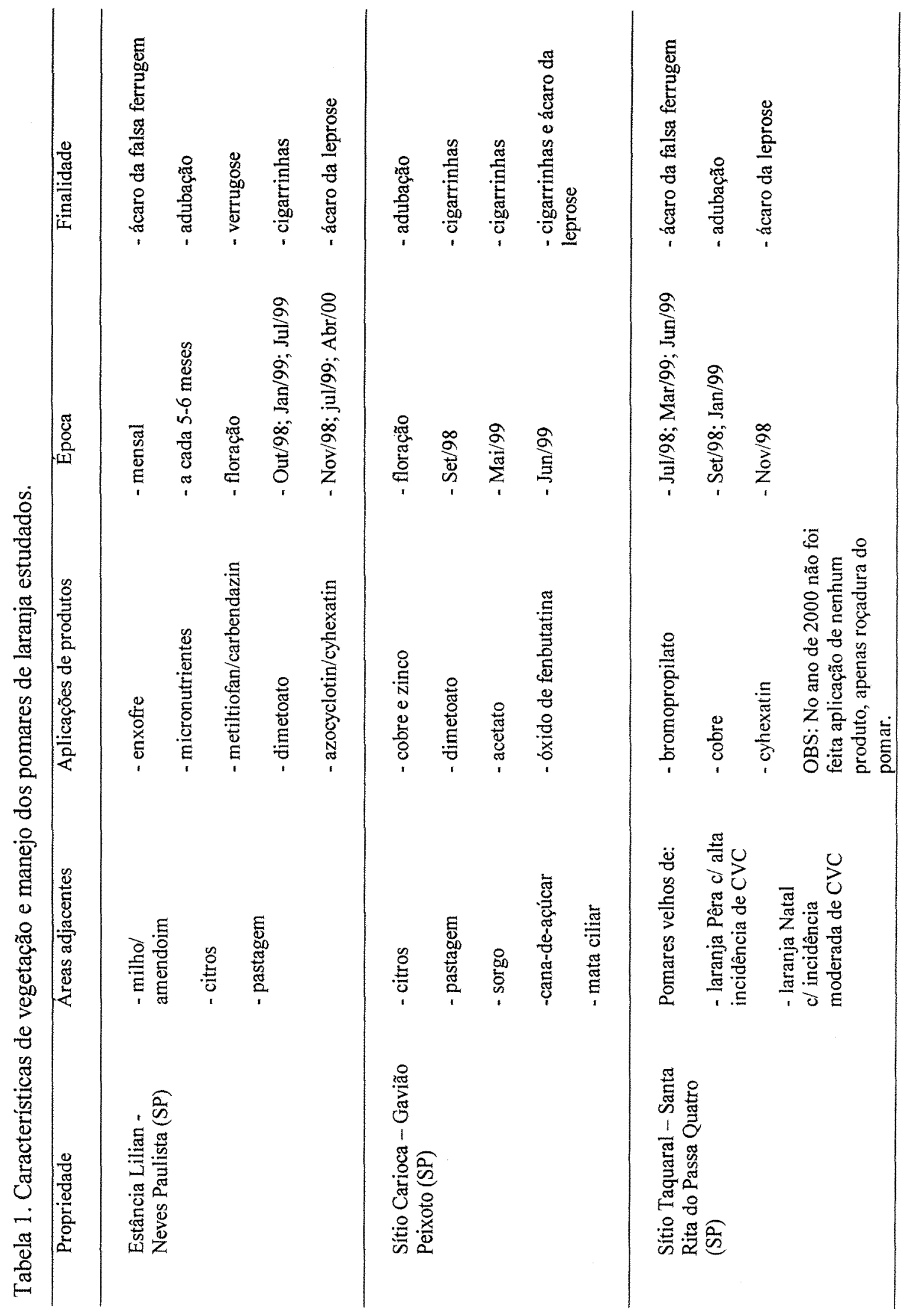


Os trabalhos de triagem e identificação das cigarrinhas capturadas nos experimentos e os testes de laboratório foram realizados no Laboratório de Insetos Vetores, situado no Departamento de Entomologia, Fitopatologia e Zoologia Agrícola da ESALQ/USP.

\subsection{Levantamento populacional}

Realizou-se levantamento populacional das cigarrinhas Acrogonia sp., Bucephalogonia xanthohis, Dilobopterus costalimai, Ferrariana trivittata, Homalodisca ignorata, Macugonailia leucomelas, Oncometopia facialis, Plesiommata corniculata, Parathona gratiosa e Sonesimia grossa (Figura 1), as quais foram identificadas como vetoras de Xylella fastidiosa em citros (Krügner et al., 1998; Descobertos, 1999).

O levantamento foi realizado nas três áreas experimentais, no período de agosto/98 a setembro/00, empregando-se duas técnicas de monitoramento: cartões adesivos amarelos e plantas-iscas (Figuras 2 e 3). A primeira é bastante utilizada e considerada um método eficiente no monitoramento de cigarrinhas pela atratividade da cor amarela a estes insetos (Timmer et al., 1982; Purcell, 1994; Purcell et al., 1997; Roberto et al., 1997). Quinzenalmente, 16 cartões adesivos amarelos de 8 x 11,2 cm foram distribuídos de maneira uniforme dentro dos talhões experimentais. Eles foram fixados nas laranjeiras a uma altura de $1,8 \mathrm{~m}$ e separados entre si por, aproximadamente, $40 \mathrm{~m}$ na linha e $30 \mathrm{~m}$ entre linhas, com $15 \mathrm{~m}$ de distância do carreador. Em junho/99, foram acrescentados mais dez pontos de cartões adesivos em cada área, visando-se aumentar as chances de captura dos vetores.

A técnica de planta-isca, que é menos convencional, envolveu a utilização de mudas de laranja doce (var. Pêra enxertada sobre limoeiro Cravo) de, aproximadamente 60-80 $\mathrm{cm}$ de altura, que foram pinceladas com substância fortemente pegajosa (The Tanglefoot Company, N-95114, EUA). Mensalmente, 20 plantas-iscas foram colocadas sobre tripés de ferro a uma altura de $1,5 \mathrm{~m}$ no interior da copa de 20 árvores (1 plantaisca/árvore) com sintomas de CVC, localizadas dentro do talhão experimental e que foram selecionadas no início do monitoramento. Após 15 dias de exposição no pomar, 
essas mudas eram inspecionadas contando-se e retirando-se as cigarrinhas capturadas, as quais eram colocadas em recipientes devidamente etiquetados.
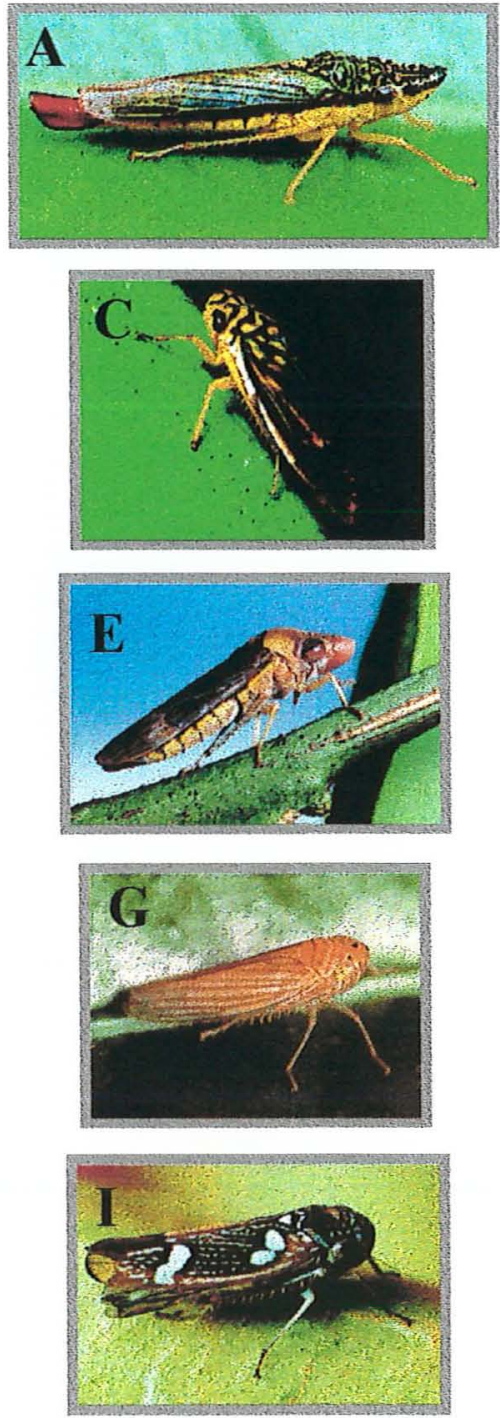
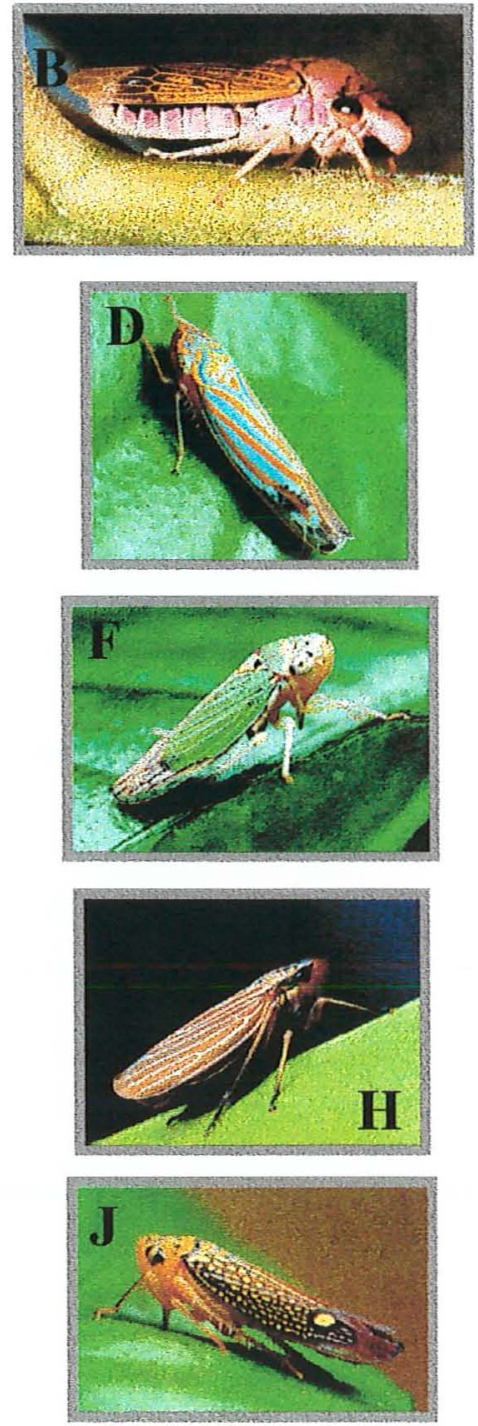

Figura 1. Espécies de cigarrinhas identificadas como vetoras de $X$. fastidiosa em citros: (A) Acrogonia sp., (B) Oncometopia facialis, (C) Dilobopterus costalimai, (D) Ferrariana trivittata, (E) Homalodisca ignorata, (F) Bucephalogonia xanthophis, (G) Plesiommata corniculata, (H) Sonesimia grossa, (I) Macugonalia leucomelas e (J) Parathona gratiosa. 


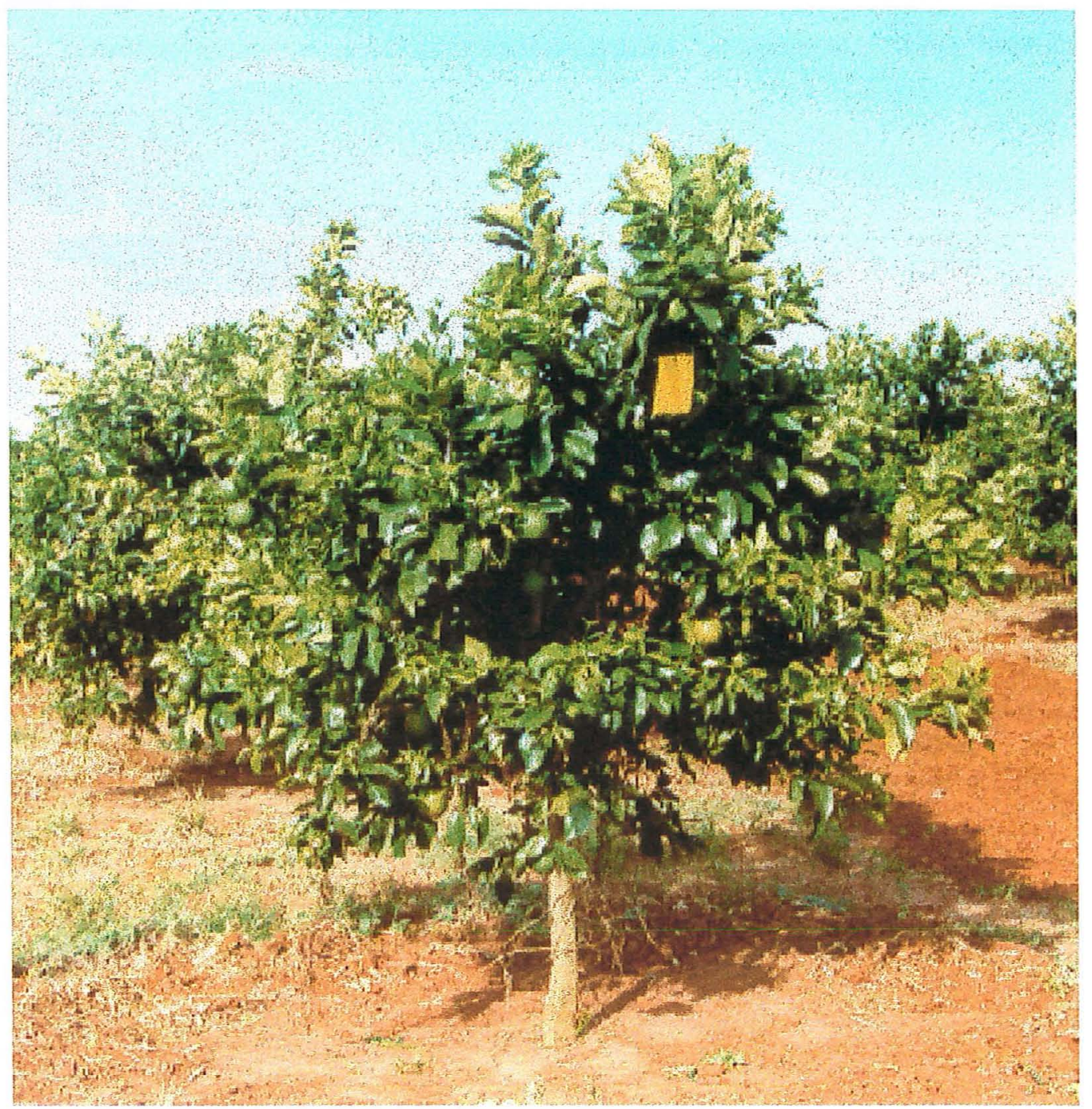

Figura 2. Cartão adesivo utilizado no monitoramento de cigarrinhas em pomares de laranja 'Pêra' localizados nos municípios paulistas de Neves Paulista, Gavião Peixoto e Santa Rita do Passa Quatro. 


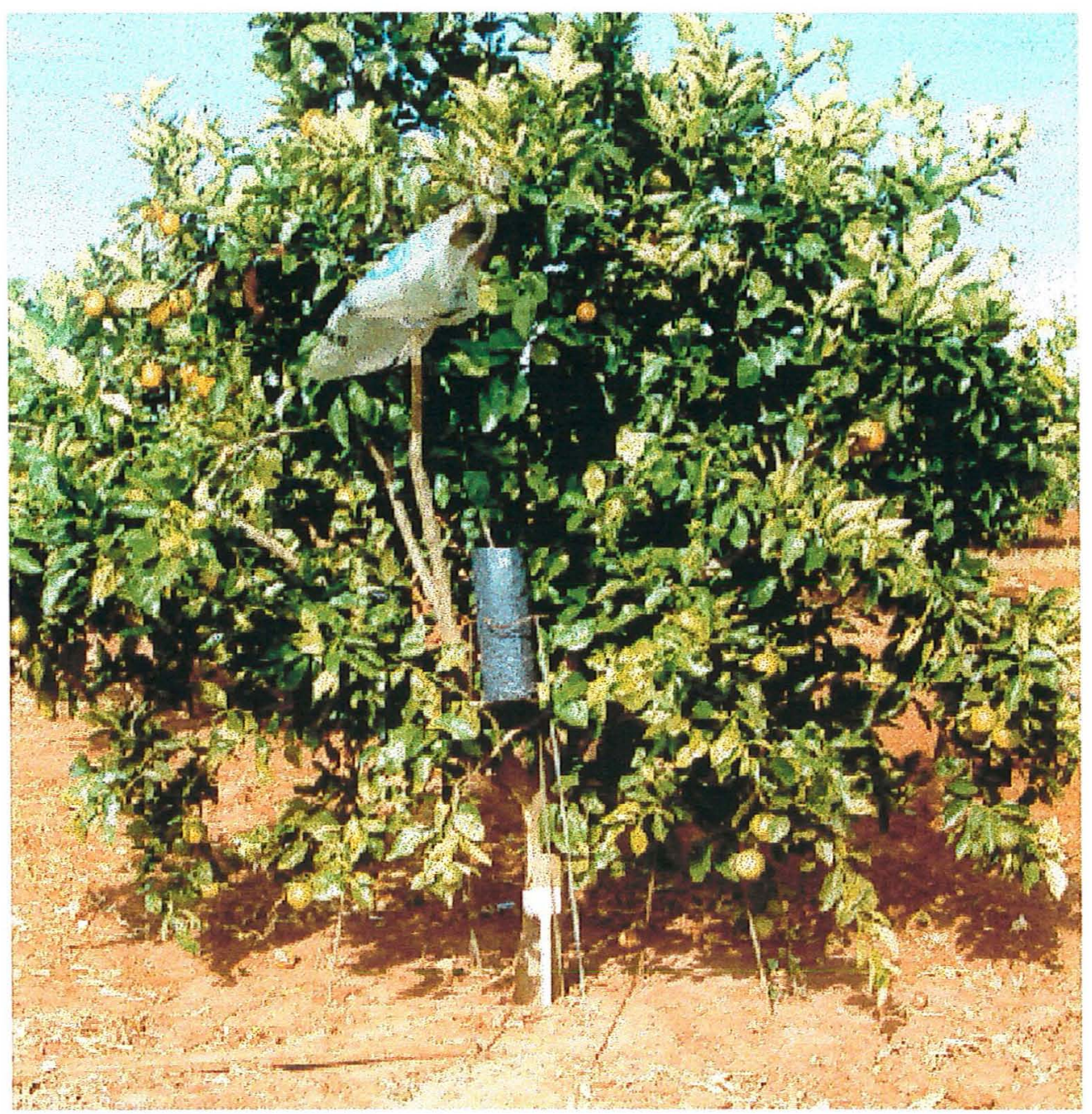

Figura 3. Planta-isca utilizada no monitoramento de cigarrinhas em pomares de laranja 'Pêra' localizados nos municípios paulistas de Neves Paulista, Gavião Peixoto e Santa Rita do Passa Quatro. 
As espécies de cigarrinhas conhecidas como vetoras (Figura 1), capturadas pelos dois métodos de amostragem, foram separadas em laboratório, quantificadas, identificadas e armazenadas a $-20^{\circ} \mathrm{C}$ para testes sorológicos. Utilizou-se o teste de $\chi^{2}$ ao nível de $5 \%$ de significância para determinar se houve diferença estatística na abundância de cada espécie de cigarrinha, capturada pelos dois métodos de monitoramento, entre os pomares estudados.

Os dados de flutuação populacional das espécies capturadas em maiores números por cartões adesivos foram correlacionados com dados mensais de temperatura e precipitação pluviométrica de cada região, através de análises de regressão. Os dados climáticos foram obtidos em postos meteorológicos distantes até $40 \mathrm{~km}$ dos talhões experimentais.

\subsection{Avaliação da infectividade natural dos vetores}

As cigarrinhas vetoras (Figura 1) capturadas por cartões adesivos amarelos e por plantas-iscas em diferentes estações do ano, foram submetidas a testes de DAS-ELISA indireto ("Double antibody sandwich - Ezime-linked immunosorbent assay") indireto para detectar a presença de $X$. fastidiosa. Os testes foram realizados utilizando-se antissoros policlonais produzidos no próprio Departamento de Entomologia, Fitopatologia e Zoologia Agrícola da ESALQ/USP.

Para a obtenção dos antissoros, foram feitas quatro injeções intramusculares, com intervalo semanal entre uma e outra, de suspensão de células de $X$. fastidiosa isolada de citros (isolado CCT 6570, Coleção de Culturas Tropicais da Fundação André Tosello, Campinas, SP) em coelho ( $\operatorname{lgG})$ e galinha ( $(\mathrm{ggY})$. Os antissoros IgG e $\operatorname{IgY}$ foram retirados do sangue do coelho e da gema do ovo da galinha, após cinco semanas da inoculação, e purificados pelo método descrito por Polson et al. (1980).

As cabeças das cigarrinhas, capturadas pelos dois métodos de monitoramento, foram maceradas em $500 \mu \mathrm{L}$ de solução tampão PBS-Tween ("Phosphate Buffered Saline") $\left(0,0015 \mathrm{M} \mathrm{KH}_{2} \mathrm{PO}_{4}, 0,14 \mathrm{M} \mathrm{NaCl}, 0,004 \mathrm{M} \mathrm{Na}_{2} \mathrm{HPO}_{4}, 0,003 \mathrm{M} \mathrm{KCl}, \mathrm{pH} 7,4+\right.$ $0,5 \mathrm{~mL}$ Tween 20), utilizando-se cadinho e pistilo. Como controle negativo para os 
testes de DAS-ELISA indireto, foram utilizadas cigarrinhas sadias das espécies Acrogonia sp., B. xanthophis, D. costalimai, $H$. ignorata e $O$. facialis, provenientes da criação do Departamento de Entomologia da ESALQ. O controle positivo foi constituído de amostras de folhas com sintomas de CVC maceradas em tampão PBS-Tween.

As placas de ELISA foram sensibilizadas com o antissoro de galinha $(\mathrm{IgY})$ diluído 1:1000 em tampão carbonato de sódio $\left(0,015 \mathrm{M} \mathrm{Na}_{2} \mathrm{CO}_{3}, 0,035 \mathrm{M} \mathrm{NaHCO}_{3}\right.$, $\mathrm{pH}$ 9,6 ) e incubadas por $1,5 \mathrm{~h}$ a $37^{\circ} \mathrm{C}$. Após tríplice lavagem das placas com PBS-Tween, adicionaram-se $100 \mu \mathrm{L}$ de cada amostra em dois pocinhos. Essas placas foram encubadas durante a noite a $4^{\circ} \mathrm{C}$ e lavadas 4 vezes com PBS-Tween na manhã seguinte, deixando-se a solução tampão na placa por $3 \mathrm{~min}$ nas duas últimas lavagens. $O$ antissoro de coelho (IgG) foi diluído na proporção de 1:500 em tampão de PBS (sem Tween) com 1\% de BSA ("Bovin serum albumin"). Essa solução foi transferida para a placa na quantidade de $100 \mu \mathrm{L}$ por pocinho, seguindo-se um período de incubação de $1,5 \mathrm{~h}$ a $37^{\circ} \mathrm{C}$. Após lavagem tríplice com PBS-Tween, adicionou-se, por pocinho, $100 \mu \mathrm{L}$ de Anti-rabbit IgG, desenvolvido em cabra e conjugado com fosfatase alcalina (Sigma A-3687, Chemical Co., St. Louis, MO, EUA), diluída 1:32.000 em tampão PBS com 2\% de PVP ("Polivinyl pyrrolidone"). Passado o período de incubação de $1,5 \mathrm{~h}$ a $37^{\circ} \mathrm{C}$, as placas foram lavadas 3 vezes com PBS-Tween e a elas adicionadas pastilhas de p-fosfato de nitrofenil (Sigma, N-9389) diluídas em tampão de dietanolamina ( $\mathrm{pH} 9,8)$ na proporção de $0,6 \mathrm{mg} / \mathrm{mL}$. As placas foram encubadas por um período de $15 \mathrm{~min}$ a $37^{\circ} \mathrm{C}$ e à temperatura ambiente por até $90 \mathrm{~min}$, no escuro, ocorrendo reação enzimática. Após 30, 60 e $90 \mathrm{~min}$, mediu-se a absorbância dos pocinhos das placas em leitor de ELISA (BIORAD, modelo 550, Califórnia, EUA), utilizando-se filtro de $405 \mathrm{~nm}$ (Van Regenmortel $\&$ Dubs, 1993). As amostras foram consideradas positivas quando apresentaram leitura pelo menos duas vezes maior que a média do controle negativo.

\subsection{Flutuação populacional de $X$. fastidiosa em árvores com CVC}

Visando-se analisar a variação sazonal no inóculo da bactéria nos pomares, realizou-se monitoramento mensal da população de células viáveis de $X$. fastidiosa em 
ramos infectados, através da técnica de isolamento em meio de cultura, no período de janeiro/99 a julho/00.

Foram selecionadas cinco árvores em cada uma das três áreas experimentais, com sintomas típicos de CVC. Essas árvores tiveram um de seus ramos sintomáticos marcados para coleta mensal de quatro folhas maduras, preferencialmente sintomáticas, do penúltimo e/ou último fluxo de crescimento, totalizando 20 folhas por área experimental. Essas folhas colocadas em sacos plásticos etiquetados e transportadas para o laboratório, em caixas de isopor contendo gelo. $\mathrm{O}$ teste de isolamento em meio de cultura foi realizado dentro de um prazo máximo de 3 dias após a coleta. As folhas foram individualizadas, avaliadas quanto à presença de sintomas e mantidas em geladeira até o momento do teste. Como controles negativos foram utilizadas folhas de mudas sadias de citros mantidas em estufas teladas; controles positivos foram retirados de plantas-fonte de $X$. fastidiosa pertencentes ao Laboratório de Insetos Vetores da ESALQ.

Para quantificação de $X$. fastidiosa em folhas cítricas, utilizou-se a técnica de isolamento primário em meio de cultura sólido PWG ("periwinkle wilt gelrite") (Hill \& Purcell, 1995), reduzindo-se o volume de água destilada na composição do meio de 1000mL para $900 \mathrm{~mL}$ (Almeida, 1999). Pedaços do pecíolo e nervura central de cada amostra foram separados com gilete e pesados em balança semi-analítica, estabelecendose um peso máximo de $0,10 \mathrm{~g}$ por amostra. A assepsia das amostras foi realizada em câmara de fluxo laminar (Veco VLFS-09, Campinas, SP), utilizando-se instrumentos previamente autoclavados. Para esterilização superficial, cada amostra passou por períodos de imersão de $2 \mathrm{~min}$, em recipientes contendo álcool $(92,8 \%)$, hipoclorito de sódio (2\%) e água destilada estéril (três vezes). Após a desinfecção, as amostras foram cortadas com gilete em pedaços de 1 a $2 \mathrm{~mm}$, sobre papel filtro, e colocadas individualmente em tubos de ensaio contendo $2 \mathrm{~mL}$ de PBS autoclavado.

As amostras foram trituradas em homogeneizador com haste giratória (modelo MA102, MARCONI Equipamentos para Laboratório S.A., Piracicaba, SP) a aproximadamente $17.000 \mathrm{rpm}$ por $10 \mathrm{a} 15 \mathrm{~s}$. Entre a trituração de uma amostra e outra, a haste que contém as lâminas do aparelho foi desinfetada por imersão em recipientes 
contendo água destilada estéril ( $5 \mathrm{~s})$, em álcool $92,8 \%$ (15 s) e novamente em água destilada estéril ( $5 \mathrm{~s})$.

A suspensão homogeneizada foi diluída $10 \mathrm{X}$ em câmara asséptica de fluxo laminar, transferindo-se $200 \mu \mathrm{L}$ de cada amostra para um novo tubo de ensaio com $2 \mathrm{~mL}$ de tampão PBS autoclavado. As amostras diluídas foram então plaqueadas em meio de cultura sólido. Duas alíquotas de $22 \mu \mathrm{L}$ de cada amostra foram pipetadas sobre o meio e escorridas com movimentos de inclinação da placa. A diluição de $10 \mathrm{X}$ utilizada nesse estudo foi definida após a execução de testes preliminares envolvendo o plaqueamento de suspensões não diluídas e diluições de $10 \mathrm{X}$ e $100 \mathrm{X}$, com o objetivo de padronizar uma diluição que minimizasse contaminações sem comprometer muito a sensitividade da técnica de isolamento.

As placas foram acondicionadas em estufa à temperatura de $28^{\circ} \mathrm{C}$, avaliando-se o número médio de unidades formadoras de colônia (UFC) das duas alíquotas, após 2 semanas do plaqueamento, sob microscópio estereoscópico. A quantificação do número de UFC por grama de tecido vegetal foi efetuada com base no peso inicial das amostras foliares e nas diluições do material vegetal em PBS. Para isso, foi utilizada a seguinte fórmula:

$$
\text { Concentração bacteriana }=100 \cdot(1 / p) \cdot \operatorname{UFC} .(10)^{\mathrm{n}}
$$

onde:

$$
\begin{aligned}
& n=\text { fator de diluição } \\
& \mathrm{p}=\text { peso da amostra foliar }(\mathrm{g})
\end{aligned}
$$

Os dados de concentração bacteriana em folhas sintomáticas das três regiões foram submetidos à análise de variância.

A identidade dos isolados de $X$. fastidiosa foi confirmada baseando-se no padrão de crescimento (aparecimento após 8-10 dias), morfologia da colônia e teste de PCR. Nos primeiros isolamentos, as colônias foram também diluídas em PBS-Tween e submetidas a teste de DAS-ELISA indireto com antissoros policlonais para X. fastidiosa, seguindo os procedimentos descritos em 3.2. 
Os testes de PCR foram conduzidos com "primers" universais para X. fastidiosa (RST31/33) (Minsavage et al., 1994) e "primers" específicos para isolados de citros (KD4/KD5) (Beretta et al., 1997), utilizando-se os dois pares de "primers" em uma mesma reação, conforme descrito por Beretta et al. (1997). De cada isolado obtido foram amostradas 1-3 colônias, as quais foram colocadas em $10 \mu \mathrm{L}$ de tampão TE (10 $\mathrm{mM}$ de Tris $\mathrm{HCl} ; 1 \mathrm{mM}$ EDTA). Desse volume, foram retirados $2 \mu \mathrm{L}$ para amplificação, sendo acrescentados $1,2 \mu \mathrm{L}$ de tampão de $\mathrm{MgCl}_{2}(4 \mathrm{mM}), 0,36 \mu \mathrm{L}$ de $\mathrm{dNTP}, 0,96 \mu \mathrm{L}$ de cada "primer" (RST31, RST33, KD4, KD5) e 1 unidade de Taq DNA polimerase por amostra de isolado, adicionando-se ao final, $30 \mu \mathrm{L}$ de óleo mineral. Como controle negativo, utilizou-se a mistura de todos os reagentes de PCR, sem a adição de colônias de bactéria. As reações foram realizadas em termociclador PTC-100 (MJ Research, Inc., Watertown, MA 02172, USA) nas seguintes condições de amplificação: $95^{\circ} \mathrm{C}$ por $1 \mathrm{~min}$ (1 ciclo), $95^{\circ} \mathrm{C}$ por $30 \mathrm{~s}, 55^{\circ} \mathrm{C}$ por $30 \mathrm{~s}, 72^{\circ} \mathrm{C}$ por $45 \mathrm{~s}, 95^{\circ} \mathrm{C}$ por $30 \mathrm{~s}\left(39\right.$ ciclos), $95^{\circ} \mathrm{C}$ por $30 \mathrm{~s}, 55^{\circ} \mathrm{C}$ por $30 \mathrm{~s}$ e $72^{\circ} \mathrm{C}$ por $5 \mathrm{~min}(1 \mathrm{ciclo})$, estabilizando a $4^{\circ} \mathrm{C}$ por tempo indeterminado.

Após adicionar $2 \mu \mathrm{L}$ de tampão de corrida (azul de bromofenol $0,25 \%$, sacarose $40 \%$ ), as amostras foram aplicadas em gel de agarose $1 \%$ com brometo de etídio ( 1 $\mu \mathrm{g} / \mathrm{mL}$ de solução) e submetidas à eletroforese em tampão TBE (100 mM Tris, $83 \mathrm{mM}$ $\mathrm{H}_{3} \mathrm{BO}_{3}$ e 1 mM EDTA). A imagem do gel foi capturada pelo sistema de documentação "Eagle Eye II" (Stratagene, La Jolla, CA 92037, USA).

Em abril/2000, quatro folhas foram retiradas de cada ramo nas áreas experimentais, sendo submetidas a testes de DAS-ELISA indireto para confirmar a presença da bactéria nas árvores por outro método.

\subsection{Efeito da época de inoculação na sobrevivência de $X$. fastidiosa em árvores cítricas}

Visando-se investigar uma possível variação sazonal na sobrevivência de infecções iniciais de $X$. fastidiosa em árvores cítricas, avaliou-se o sucesso de 
inoculações mecânicas e de transmissão dessa bactéria por cigarrinhas vetoras em diferentes épocas do ano.

\subsubsection{Inoculações mecânicas}

Foram realizadas inoculações de suspensões de $X$. fastidiosa através de alfinete entomológico em ramos de árvores cítricas dos pomares localizados nas regiões sul (Santa Rita do Passa Quatro) e noroeste (Neves Paulista) do Estado de São Paulo, nos dias 19-20/02/99 (verão), 20-21/05/99 (outono), 24-26/09/99 (início de primavera) e 1415/12/99 (final de primavera).

Em cada pomar e data de inoculação, quinze árvores cítricas sem sintomas de CVC foram selecionadas. Quatro ramos com brotações, localizados no terço apical de cada árvore e designados A, B, C e D, foram marcados com fita plástica para posterior inoculação. Para detecção de possíveis infecções latentes de $X$. fastidiosa nos ramos marcados, duas folhas coletadas na base do último fluxo de brotação e na base do penúltimo de cada ramo foram submetidas ao teste de isolamento em meio de cultura e/ou teste de DAS-ELISA indireto, conforme descrito nos itens 3.2 e 3.3 , respectivamente. Ramos que apresentaram infecções pré-existentes do patógeno por qualquer um dos dois testes foram excluídos do experimento.

$\mathrm{O}$ isolado de $X$. fastidiosa, usado em todas as inoculações mecânicas, foi obtido de uma muda de laranja doce infectada com inóculo proveniente de Bebedouro, SP. O isolado foi purificado e multiplicado em meio sólido PWG para então ser preservado a $-80^{\circ} \mathrm{C}$. Esse isolado encontra-se depositado na Coleção de Culturas Tropicais da Fundação André Tosello (Campinas, SP) sob números de serviço OS 001066 e de acesso CCT 7157.

Placas contendo colônias do isolado CCT 7157, repicadas 2-4 vezes em meio sólido PWG, foram levadas ao campo para preparo do inoculo. As colônias foram raspadas das placas com o auxílio de uma alça de platina e homogeneizadas em tampão PBS até que uma concentração de aproximadamente $10^{8} \mathrm{UFC} / \mathrm{mL}$ fosse obtida, baseando-se em uma escala de turbidez (Escala de McFarland) (Lelliott \& Stead, 1987). 
Nessa concentração, a suspensão apresentava-se tipicamente esbranquiçada. Também foram realizados alguns testes preliminares em laboratório envolvendo plaqueamento, visando-se correlacionar o nível de turbidez com a concentração bacteriana das suspensões. As suspensões bacterianas produzidas em campo foram mantidas em isopor com gelo, sendo substituídas após 40 min de uso, de modo a manter a viabilidade do inóculo.

Os ramos selecionados foram inoculados com uma gota de $5 \mu \mathrm{L}$ da suspensão depositada no terço apical da haste do último fluxo de brotação. Para a absorção do inóculo pelo sistema vascular, foram efetuadas cinco perfurações na haste, sob a gota, com um alfinete entomológico No. 0 . Em cada perfuração, a haste foi transpassada pelo alfinete. $O$ ponto de inoculação foi marcado, $1 \mathrm{~cm}$ abaixo, com um anel de tinta. As inoculações foram realizadas nas horas mais quentes do dia, quando a absorção do inoculo pela planta é mais rápida (1-3 min). Após a inoculação, os ramos foram envoltos com sacos de tule a fim de evitar re-inoculações naturais por vetores e as árvores foram pulverizadas no tronco com inseticida sistêmico $[5 \mathrm{~mL}$ de imidacloprid (Winner) por planta].

As avaliações de viabilidade da bactéria inoculada foram realizadas após 4 (ramos A), 8 (ramos B), 12 (ramos C) e 16 (ramos D) semanas da inoculação, amostrando-se as folhas localizadas logo acima $(\approx 1,5 \mathrm{~cm})$ e abaixo $(\approx 1,5 \mathrm{~cm})$ do ponto de inoculação. Essas amostras foram submetidas ao teste de isolamento em meio de cultura, para detecção de células viáveis de $X$ fastidiosa. Após 20 semanas de cada inoculação, todos os ramos inoculados foram podados a $1 \mathrm{~m}$ abaixo do ponto de inoculação. Os ramos podados foram transportados para o laboratório, onde foi feita avaliação de sintomas de CVC e amostragem de folhas localizadas a aproximadamente 3 e $10 \mathrm{~cm}$ acima e abaixo do ponto de inoculação. As folhas retiradas a $3 \mathrm{~cm}$ do ponto de inoculação foram submetidas ao teste de isolamento e quantificação em meio de cultura, enquanto que as amostras foliares retiradas a $10 \mathrm{~cm}$ foram testadas por DAS-ELISA indireto ou cultura (no caso de ramos positivos em avaliações anteriores). Para os testes de DAS-ELISA indireto e de isolamento e quantificação de $X$. fastidiosa nas amostras foliares, foram utilizados os mesmos procedimentos descritos em 3.2 e 3.3, 
respectivamente. Amostras das colônias recuperadas em cultura foram testadas por PCR (conforme descrito em 3.3) para confirmação da presença da bactéria $X$. fastidiosa.

Os dados de proporção de ramos positivos por cultura, por DAS-ELISA e por cultura + DAS-ELISA, obtidos para as quatro épocas de inoculações e duas localidades, foram submetidos ao teste de $\chi^{2}$ ao nível de $5 \%$ de significância.

\subsubsection{Inoculação com cigarrinhas vetoras}

Adultos das cigarrinhas $O$. facialis e $D$. costalimai foram coletados em pomares cítricos na região de Bebedouro (SP) e mantidos em mudas cítricas no Laboratório de Insetos Vetores da ESALQ/USP. A espécie $O$. facialis foi utilizada em duas inoculações de ramos sadios de árvores cítricas, realizadas em 20/04/99 e 10/06/99, enquanto que a espécie D. costalimai foi utilizada em outras duas inoculações, realizadas em 17/09/99 e 14/12/99. Todos os testes de transmissão foram realizados no pomar localizado no município de Gavião Peixoto, na região central do estado.

Para cada época de inoculação, árvores cítricas sem sintomas de CVC foram selecionadas arbitrariamente dentro do talhão experimental, sendo que ramos do último fluxo de crescimento, localizados no terço apical de cada árvore, foram marcados com fita plástica para posterior inoculação. Para detecção de possíveis infecções latentes de $X$. fastidiosa nos ramos marcados, duas folhas coletadas na base do último fluxo de brotação e na base do penúltimo de cada ramo foram submetidas ao teste de isolamento em meio de cultura e/ou teste de DAS-ELISA indireto, conforme descrito nos itens $3.2 \mathrm{e}$ 3.3, respectivamente. Ramos que apresentaram infecções pré-existentes do patógeno por qualquer um dos dois testes foram excluídos do experimento.

Para cada teste de transmissão, as cigarrinhas provenientes de campo foram submetidas a um período de acesso à aquisição (PAA) de $48 \mathrm{~h}$ em plantas-fonte de $X$. fastidiosa, em casa de vegetação, sendo em seguida confinadas sobre mudas cítricas sadias cobertas com saco de tule, e levadas ao campo para inoculação dos ramos sadios previamente marcados. Gaiolas retangulares de isopor $(12 \times 16 \mathrm{~cm})$, com tela de "voil", foram fixadas nesses ramos para confinamento das cigarrinhas durante a inoculação, 
sendo que os insetos foram introduzidos nas mesmas através de um aspirador bucal. $\mathrm{O}$ período de acesso à inoculação ( $\mathrm{PAI}$ ) foi de $48 \mathrm{~h}$, após o qual as cigarrinhas foram retiradas e avaliadas quanto à sobrevivência. Ramos inoculados em que a sobrevivência das cigarrinhas foi inferior a $60 \%$ ao final do PAI, foram descartados do experimento. Os ramos expostos aos vetores foram cobertos com sacos de tule para evitar reinoculações naturais e as árvores foram pulverizadas no tronco com inseticida sistêmico [5 mL de imidacloprid (Winner) por árvore].

Oito meses após a inoculação, foram realizados testes de DAS-ELISA indireto com amostras de três folhas retiradas da porção dos ramos onde as cigarrinhas foram confinadas, e de isolamento em meio de cultura das demais folhas retiradas do mesmo local. Os testes foram conduzidos seguindo metodologia descrita em 3.2 e 3.3. 


\section{RESULTADOS E DISCUSSÃO}

\subsection{Levantamento populacional de vetores nas áreas estudadas}

Cigarrinhas vetoras de $X$. fastidiosa foram capturadas nos pomares das áreas estudadas tanto por cartões adesivos quanto por plantas-iscas. Os cartões adesivos capturaram 6,5, 2,1 e 12,9 vezes mais cigarrinhas nos pomares de Neves Paulista (noroeste), Gavião Peixoto (centro) e Santa Rita do Passa Quatro (sul), respectivamente, em comparação às plantas-iscas (Tabela 2). Esse fato correspondeu ao esperado, pois a armadilha adesiva amarela apresenta alto potencial atrativo sobre tais insetos vetores (Purcell, 1994; Purcell \& Elkinton, 1980; Cherry \& Howard, 1984). Porém, apesar dos cartões adesivos possuírem atratividade, algumas espécies de cigarrinhas podem não ser atraídas tanto quanto outras.

A espécie Acrogonia sp. foi capturada em maior quantidade pelos cartões adesivos distribuídos nos pomares das regiões noroeste e central, enquanto que no pomar da região sul, a espécie predominante foi a Dilobopterus costalimai, tanto pelo método dos cartões adesivos quanto pelas plantas-iscas (Tabela 2).

No pomar da região noroeste, $D$. costalimai foi capturada em maior quantidade pelas plantas-iscas, enquanto que na região central, não houve uma diferença relevante no total de indivíduos de cada espécie capturados por esse método (Tabela 2).

Os cartões adesivos capturaram 3,6 e 4,4 vezes mais cigarrinhas no pomar da região sul que nos pomares das regiões central e noroeste, respectivamente. As plantasiscas capturaram maior número de cigarrinhas no pomar do centro do Estado. Esse número foi 3,7 e 1,7 vezes maior em relação à quantidade capturada nos pomares das regiões noroeste e sul, respectivamente (Tabela 2). 


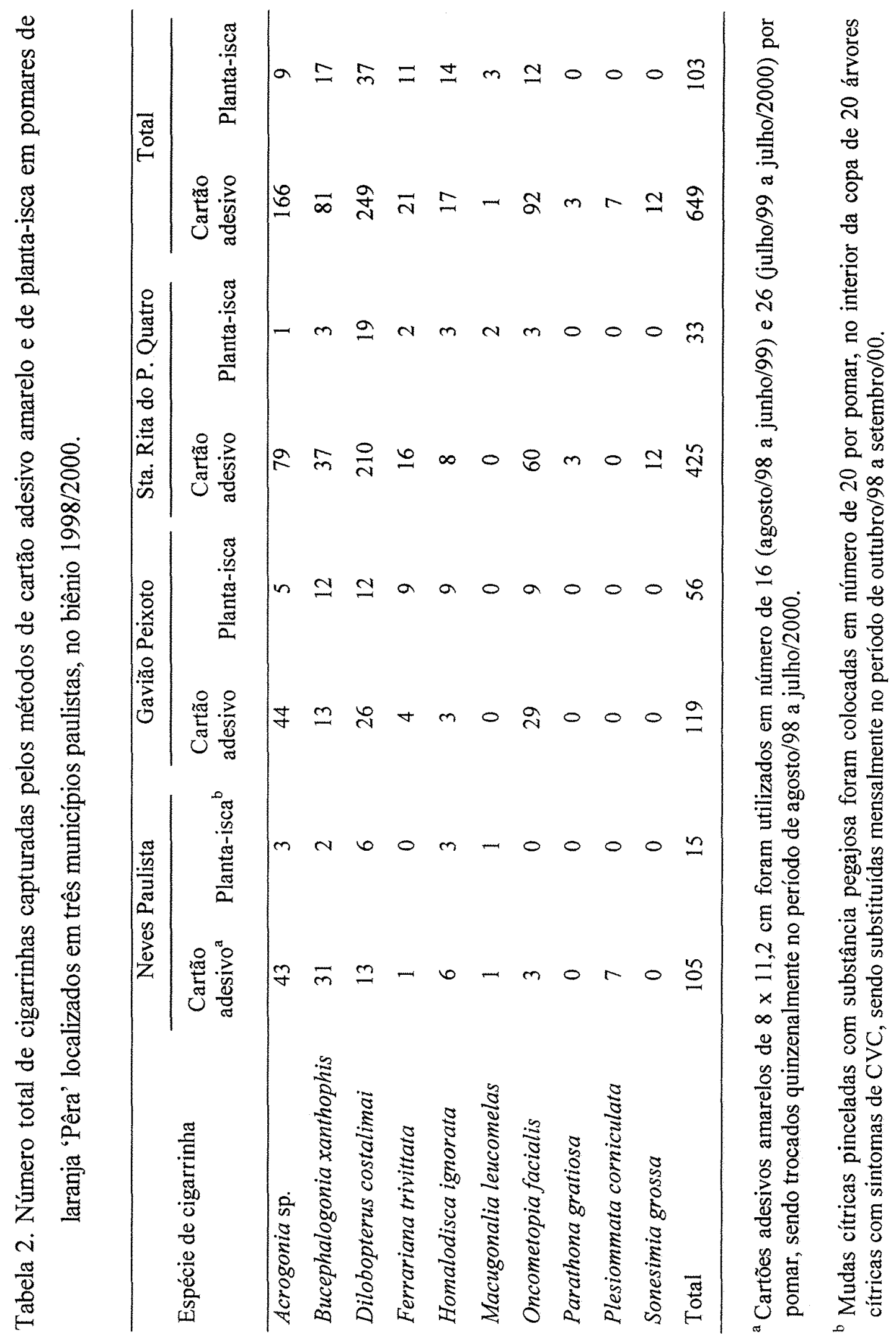


Foi observado que os cartões adesivos capturaram outras espécies de vetores, tais como Macugonalia leucomelas, Parathona gratiosa e Sonesimia grossa, porém em quantidades mínimas (Tabela 2).

Houve diferença estatística significativa entre o total de indivíduos de cada espécie capturados nos três pomares estudados, pelo método de cartões adesivos, para Acrogonia sp., B. xanthophis, D. costalimai e O. facialis (Tabela 3). Para o método de plantas-iscas, foi verificada diferença estatística significativa apenas para as espécies $D$. costalimai e Ferrariana trivittata (Tabela 4).

Em números absolutos, a população de cigarrinhas capturadas foi maior no pomar situado na região sul (Tabela 2). Esse fato pode ter sido influenciado pela ausência de pulverizações para o controle dos vetores nessa área, o que não ocorreu nas demais. Diferenças estatísticas no total de indivíduos capturados de cada espécie entre os pomares estudados ocorreram, principalmente, pelo método dos cartões adesivos, que mostrou uma maior captura de cigarrinhas em relação às plantas-iscas.

Tabela 3. Comparação entre o número de indivíduos de cada espécie de cigarrinha capturados por cartões adesivos em pomares de laranja 'Pêra' de três regiões da citricultura paulista, no período de agosto/1998 a julho/2000.

\begin{tabular}{lcccc}
\hline \multicolumn{1}{c}{ Espécie } & Região de ocorrência & $\mathrm{X}^{2}$ & gl & $\mathrm{P}^{\mathrm{a}}$ \\
\hline Acrogonia sp. & $\mathrm{N}^{\mathrm{b}}, \mathrm{C}^{\mathrm{c}} \mathrm{e} \mathrm{S}$ & 32.0661 & 2 & 0 \\
Bucephalogonia xanthophis & $\mathrm{N}, \mathrm{C} \mathrm{e} \mathrm{S}$ & 33.7298 & 2 & 0 \\
Dilobopterus costalimai & $\mathrm{N}, \mathrm{C} \mathrm{e} \mathrm{S}$ & 65.6404 & 2 & 0 \\
Ferrariana trivittata & $\mathrm{C} \mathrm{e} \mathrm{S}$ & 2.1342 & 1 & 0,344 \\
Homalodisca ignorata & $\mathrm{N}, \mathrm{C} \mathrm{e} \mathrm{S}$ & 4.8524 & 2 & 0,0884 \\
Oncometopia facialis & $\mathrm{N}, \mathrm{C} \mathrm{e} \mathrm{S}$ & 71.3401 & 2 & 0 \\
\hline
\end{tabular}

${ }^{\mathrm{a}}$ Diferença significativa se $\mathrm{p}<0,05$.

${ }^{\mathrm{b}}$ Região noroeste (município de Neves Paulista)

${ }^{\mathrm{c}}$ Região central (município de Gavião Peixoto)

${ }^{d}$ Região sul (município de Santa Rita do Passa Quatro) 
Tabela 4. Comparação entre o número de indivíduos de cada espécie de cigarrinha capturados por plantas-iscas em pomares de laranja 'Pêra' de três regiões da citricultura paulista, no período de agosto/1998 a julho/2000.

\begin{tabular}{lcccc}
\hline \multicolumn{1}{c}{ Espécie } & Região de ocorrência & $\mathrm{X}^{2}$ & $\mathrm{gl}$ & $\mathrm{P}^{\mathrm{a}}$ \\
\hline Acrogonia sp. & $\mathrm{N}^{\mathrm{b}}, \mathrm{C}^{\mathrm{c}} \mathrm{e} \mathrm{S}$ & 3.7683 & 2 & 0.152 \\
Bucephalogonia xanthophis & $\mathrm{N}, \mathrm{C} \mathrm{e} \mathrm{S}$ & 2.4278 & 2 & 0.297 \\
Dilobopterus costalimai & $\mathrm{N}, \mathrm{C} \mathrm{e} \mathrm{S}$ & 11.9869 & 2 & 0.0025 \\
Ferrariana trivittata & $\mathrm{C} \mathrm{e} \mathrm{S}$ & 8.6914 & 1 & 0.0032 \\
Homalodisca ignorata & $\mathrm{N}, \mathrm{C} \mathrm{e} \mathrm{S}$ & 1.2614 & 2 & 0.5322 \\
Macugonalia leucomelas & $\mathrm{C} \mathrm{e} \mathrm{S}$ & 0.0793 & 1 & 0.7782 \\
Oncometopia facialis & $\mathrm{C} \mathrm{e} \mathrm{S}$ & 0.3722 & 1 & 0.5418 \\
\hline
\end{tabular}

${ }^{a}$ Diferença significativa se $\mathrm{p}<0,05$.

${ }^{\text {b }}$ Região noroeste (município de Neves Paulista)

${ }^{c}$ Região central (município de Gavião Peixoto)

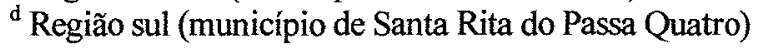

Como as plantas-iscas representam um método de captura passivo, as cigarrinhas capturadas, podiam pousar eventualmente nessas plantas, dando uma pequena estimativa das espécies que estavam visitando a árvore na qual se encontravam camufladas. Um fator que deve ser considerado, é que as árvores cítricas onde se encontravam, apresentavam sintomas evidentes de $\mathrm{CVC}$, e que nem sempre essas plantas-iscas apresentavam brotações, podendo ter reduzido a chance de captura de vetores. Confirmando essa possibilidade, pode-se destacar um trabalho realizado por Martins et al. (2000), baseado em trabalhos prévios de Laranjeira (1997), que sugeriram que as cigarrinhas executam vôos longos para alimentação ao acaso (modelo de vôo de Lévy), procurando plantas não estressadas e com novos crescimentos vegetativos, baseados nas variáveis de mobilidade das cigarrinhas, nível de estresse e nutricional da planta e os efeitos sazonais de clima.

As espécies capturadas com maior freqüência nos pomares estudados, Acrogonia sp., D. costalimai e O. facialis, foram relatadas por Paiva et al. (1996) como sendo de ocorrência quase que exclusiva nas plantas cítricas em pomares. A espécie $B$. xanthophis, que ocorre em plantas cítricas e em plantas invasoras (Paiva et al., 1996; 
Yamamoto, 1998; Roberto \& Yamamoto, 2000), foi capturada com freqüência nos pomares das três áreas, podendo apresentar importância significativa na disseminação da doença, já que sua eficiência de transmissão de $X$. fastidiosa para citros é de $11,7 \%$ (Krügner et al., 1998).

B. xanthophis é a cigarrinha vetora mais freqüente em viveiros cítricos no Estado de São Paulo (Roberto et al., 2000). As espécies F. trivittata e Sonesimia grossa, que habitam preferencialmente plantas invasoras do pomar (Paiva et al., 1996; Yamamoto, 1998), e que foram recentemente confirmadas como vetoras da $X$. fastidiosa (Descobertos, 1999) foram capturadas nas plantas-iscas das áreas experimentais. Esse fato indica que $F$. trivittata e $S$. grossa pousam sobre ramos de árvores cítricas, podendo, através da alimentação, adquirir e/ou inocular $X$. fastidiosa.

A espécie Macugonalia leucomelas, que ocorre tanto em plantas invasoras quanto em árvores de citros (Paiva et al., 1996; Yamamoto, 1998), foi capturada em pequena quantidade pelos cartões adesivos, no pomar da região noroeste, e pelas plantas-iscas nos pomares das regiões noroeste e sul (Tabela 2). Em estudo recente, verificou-se que a espécie Macugonalia leucomelas transmite $X$. fastidiosa para citros com eficiência relativamente alta (Descobertos, 1999).

Outra espécie descrita recentemente como vetora (Descobertos, 1999), a $H$. ignorata, foi capturada nos três pomares estudados, porém, em pequena quantidade. Nos EUA, duas espécies vetoras pertencentes ao mesmo gênero, H.coagulata e H. lacerta, estão causando problemas econômicos novos em cultivos de fumo e ornamentais, especialmente em uma espécie de espirradeira (Nerium oleander) (Blua et al., 1999; Purcell \& Saunders, 1999). Purcell \& Saunders (1999) demonstraram a capacidade de H.coagulata transmitir estirpes causadoras de PD de videira para videira e amendoeira, e de $N$. oleander para plantas sadias da mesma espécie. No Brasil, sabe-se que a espécie H. ignorata, que ocorre em citros, possui baixa eficiência de transmissão (Descobertos, 1999). 


\subsection{Flutuação populacional dos vetores}

O pomar situado na região noroeste apresentou maiores picos populacionais de cigarrinhas durante a primavera de 1998 e início do verão de 1999 (Figura 4). No segundo ano de monitoramento, não foram observados grandes picos populacionais nessa mesma época. As espécies Acrogonia sp. e B. xanthophis foram capturadas em maior quantidade nesse período, porém ocorrendo praticamente durante todos os meses de avaliação em menores quantidades. As cigarrinhas $D$. costalimai e $O$. facialis foram capturadas com menor freqüência que as anteriores, apresentando picos também nos meses correspondentes ao final da primavera e início do verão de 1999. Apenas a $O$. facialis não foi capturada nos meses subseqüentes.

A região noroeste caracterizou-se por apresentar temperaturas médias entre $19^{\circ} \mathrm{C}$ e $28^{\circ} \mathrm{C}$ (Figura 4). A maior elevação da temperatura e concentração de chuvas também ocorreu na primavera-verão. Em 1999, um período de estiagem mais prolongado nos meses de inverno pode ter afetado a população de cigarrinhas, que se manteve baixa nos meses posteriores. No decorrer desse estudo, o produtor de Neves Paulista realizou quatro aplicações de inseticidas direcionadas ao controle das cigarrinhas de citros, nos meses de outubro de 1998, janeiro e julho de 1999, e abril de 2000 (Tabela 1), o que pode ter provocado a diminuição do número de cigarrinhas e conseqüentemente a sua população.

O pomar situado na região central caracterizou-se por apresentar temperaturas médias entre $19^{\circ} \mathrm{C}$ e $25^{\circ} \mathrm{C}$, atingindo picos mais elevados de temperatura, bem como maior concentração de chuvas, nos meses correspondentes ao final da primavera e início do verão (Figura 5). Períodos de estiagem prolongada também ocorreram nessa região nos meses de maio/99 a novembro/99 e de abril a outubro de 2000. A primavera, que normalmente apresenta chuvas regulares, foi mais seca nos anos de 1999 e 2000 do que em 1998. A população de cigarrinhas apresentou seus maiores picos em Gavião Peixoto 

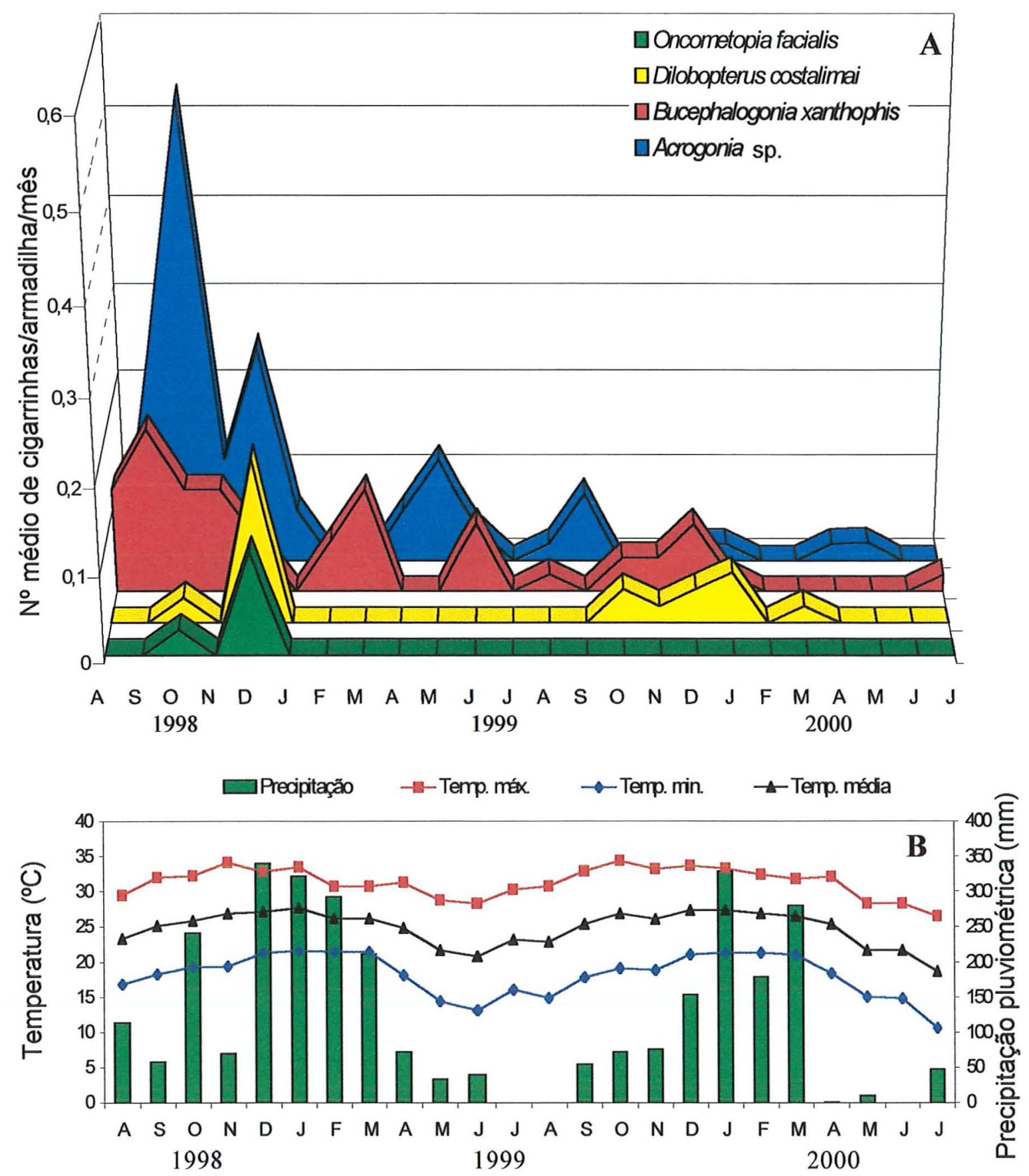

Figura 4. A) Flutuação populacional de adultos de cigarrinhas capturados por cartões adesivos amarelos em pomares de laranja 'Pêra', no município de Neves Paulista (SP), no período de agosto/1998 a julho/2000. B) Dados de precipitação pluviométrica e temperatura (médias) registrados para o período. 

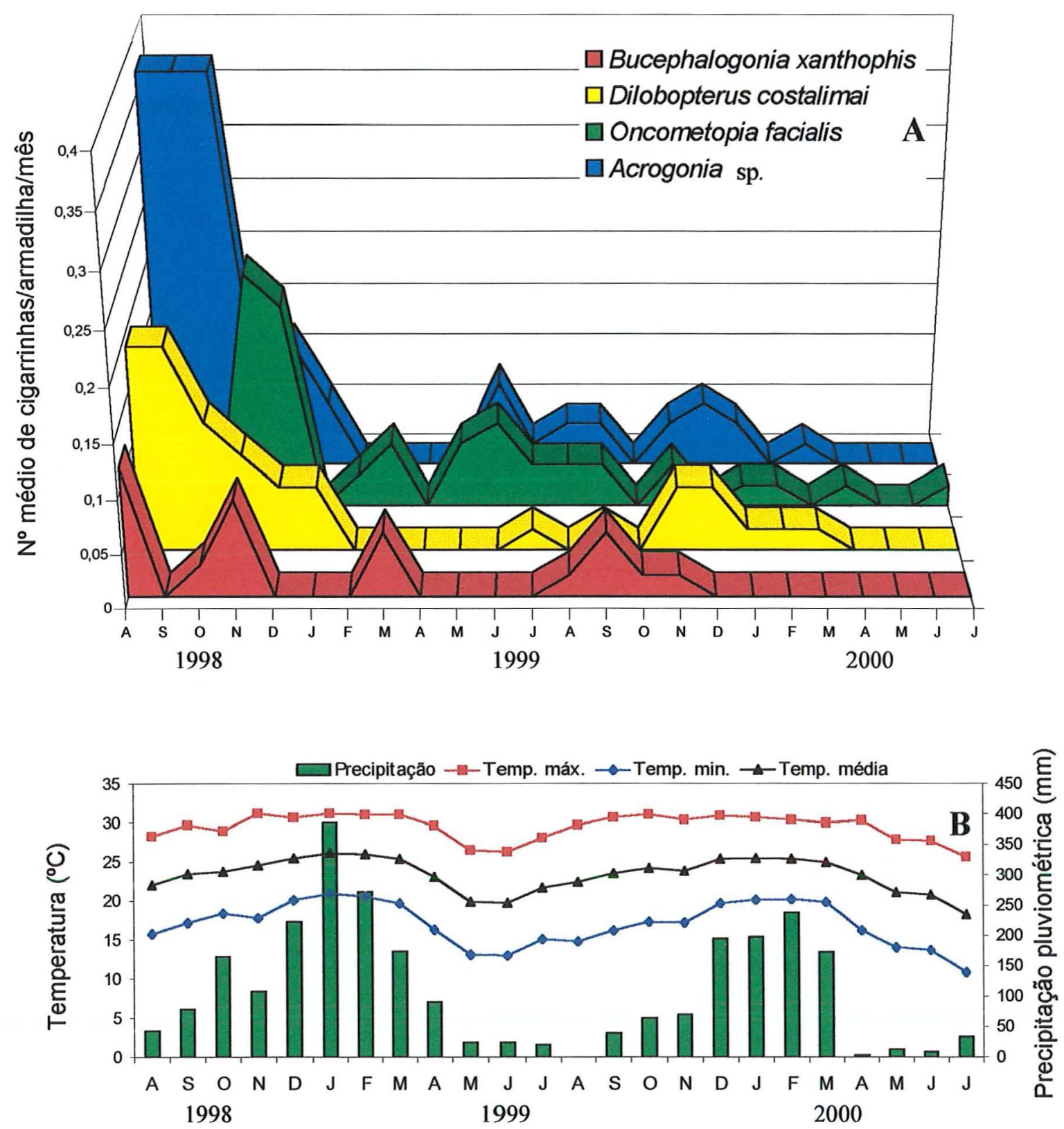

Figura 5. A) Flutuação populacional de adultos de cigarrinhas capturados por cartões adesivos amarelos em pomar de laranja 'Pêra', no município de Gavião Peixoto (SP), no período de agosto/1998 a julho/2000. B) Dados de precipitação pluviométrica e de temperatura (médias) registrados para o período. 
entre agosto/98 e janeiro/99, embora esses insetos tenham sido capturados ao longo de todo o período amostral. Nesse pomar também houve a utilização de inseticidas para o controle das cigarrinhas, tais como dimetoato, acefato e óxido de fenbutatina, nos meses de setembro/98 e maio/99 (Tabela 1).

O pomar situado na região sul apresentou maiores concentrações de chuva durante o final da primavera e início do verão, principalmente nos meses de dezembro a fevereiro, e menor concentração entre abril e setembro (Figura 6). As temperaturas médias variaram entre $17^{\circ} \mathrm{C}$ e $24^{\circ} \mathrm{C}$. A espécie $D$. costalimai esteve presente em números relativamente altos durante praticamente todo o período avaliado, com pico mais pronunciado entre os meses de julho a setembro de 1999. Já a espécie Acrogonia sp. apresentou seu maior pico populacional em outubro/98. As demais espécies capturadas apresentaram pequenos picos ao longo do período de estudo, inclusive nos meses mais frios e secos. Considerando-se as quatro espécies vetoras, houve tendência de maior população no período de fevereiro a outubro (final do verão ao início da primavera).

Paiva et al. (1996), utilizando um succionador motorizado para a coleta de cigarrinhas vetoras de $X$. fastidiosa, em diferentes épocas do ano, obteve maiores quantidades de três espécies de cigarrinhas durante os meses de verão do primeiro ano e outono e inverno, nos dois anos consecutivos. Yamamoto (1998), trabalhando com o succionador e cartões adesivos, coletou maior número de cigarrinhas durante os meses de verão e outono. Roberto (1998), utilizando cartões adesivos para estudar a flutuação populacional de cigarrinhas, relatou que a maior atividade desses insetos ocorre durante a primavera e verão, apenas havendo diferenças na abundância em quatro anos de amostragem. Roberto \& Yamamoto (1998) relatam que a população de cigarrinhas é influenciada pelo clima, com tendência a ser maior em anos com distribuição normal de chuvas, ocorrendo colonização dos pomares no início da primavera. 

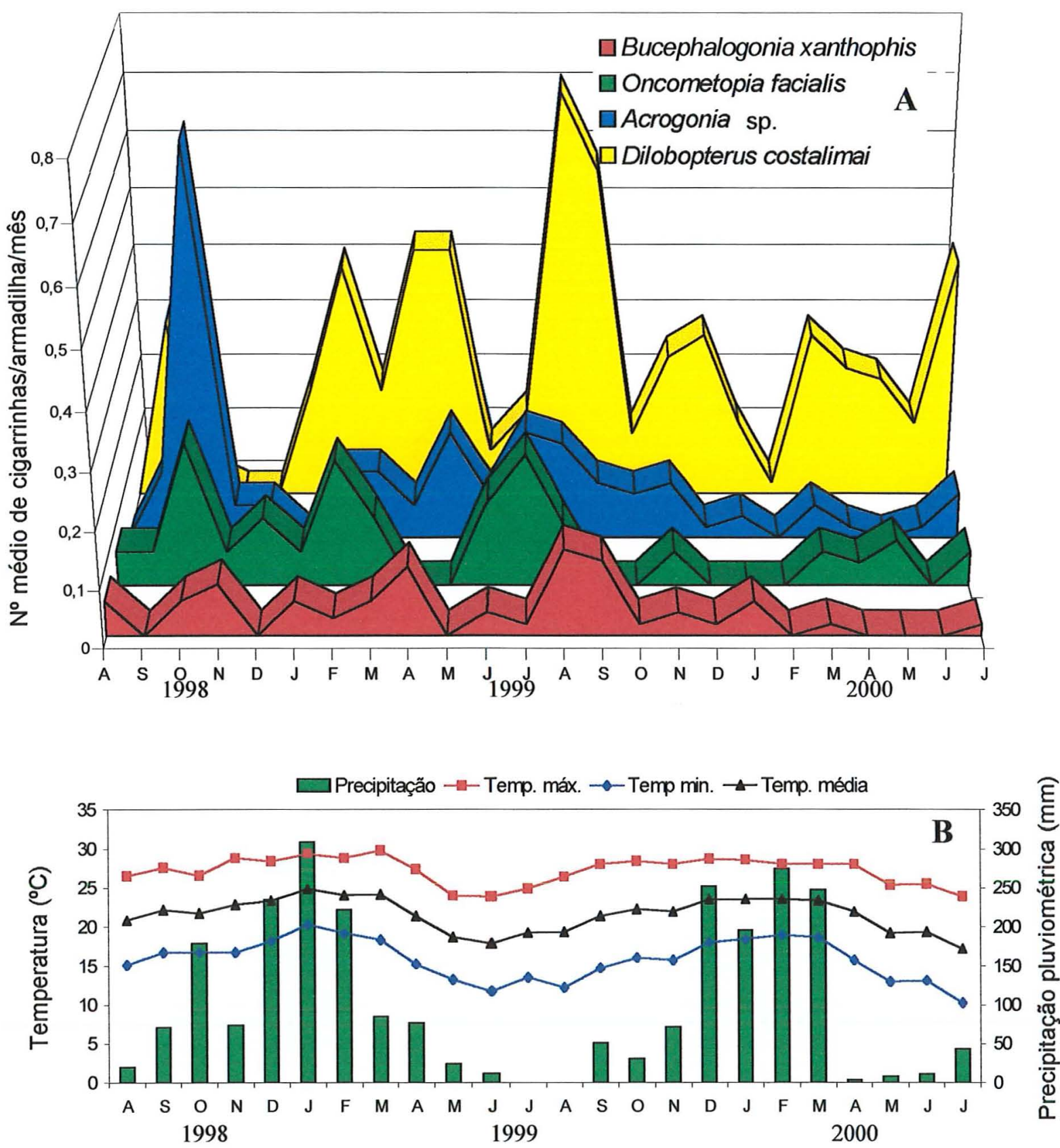

Figura 6. A) Flutuação populacional de adultos de cigarrinhas capturados por cartões adesivos amarelos em pomares de laranja 'Pêra', no município de Santa Rita do Passa Quatro (SP), no período de agosto/1998 a julho/2000. B) Dados de precipitação pluviométrica e de temperatura (médias) registrados para o período. 
Considerando-se que os dados de precipitação pluviométrica e temperatura apresentaram pouca variação entre as regiões experimentais, supõe-se que a maior freqüência de captura de cigarrinhas na região sul pode ter ocorrido pela ausência de aplicação de inseticidas no pomar de Santa Rita do Passa Quatro (Tabela 1), pois o controle químico é eficiente no controle das cigarrinhas vetoras (Roberto \& Yamamoto, 1998; Lopes, 1999). Foram feitas análises de regressão entre a população das cigarrinhas Acrogonia sp. e D. costalimai e as variáveis climáticas, temperatura média e precipitação pluviométrica (Tabela 5). Entretanto, as análises não indicaram nenhuma correlação significativa. A estiagem prolongada em 1999 e 2000 pode ter sido outro fator que interferiu negativamente na população dos insetos.

Em levantamentos de cigarrinhas em pomares do Estado de São Paulo, no período de dezembro/94 a abril/97, Roberto \& Yamamoto (1998) observaram efeito semelhante devido a uma estiagem prolongada durante o segundo ano de monitoramento. Segundo Hoffman \& Hogg (1991), o déficit hídrico pode influenciar a população das cigarrinhas reduzindo sua taxa reprodutiva e sua fecundidade, além de aumentar seu ciclo de desenvolvimento.

Como as cigarrinhas apresentam pouca especificidade hospedeira (Lopes, 1999) e uma vasta gama de espécies vegetais nas quais podem se alimentar e reproduzir (Purcell \& Saunders, 1999; Leite et al., 1997; Lopes, 1999), pode estar ocorrendo uma migração de fora para dentro do pomar, e que explicaria a presença desses insetos durante praticamente o ano todo, mesmo após a aplicação de inseticidas ou períodos climáticos desfavoráveis. Estudos em andamento têm indicado a ocorrência desses vetores em vários tipos de vegetação adjacentes a pomares cítricos na região de Bebedouro, SP (Lopes \& Giustolin, 2000). 


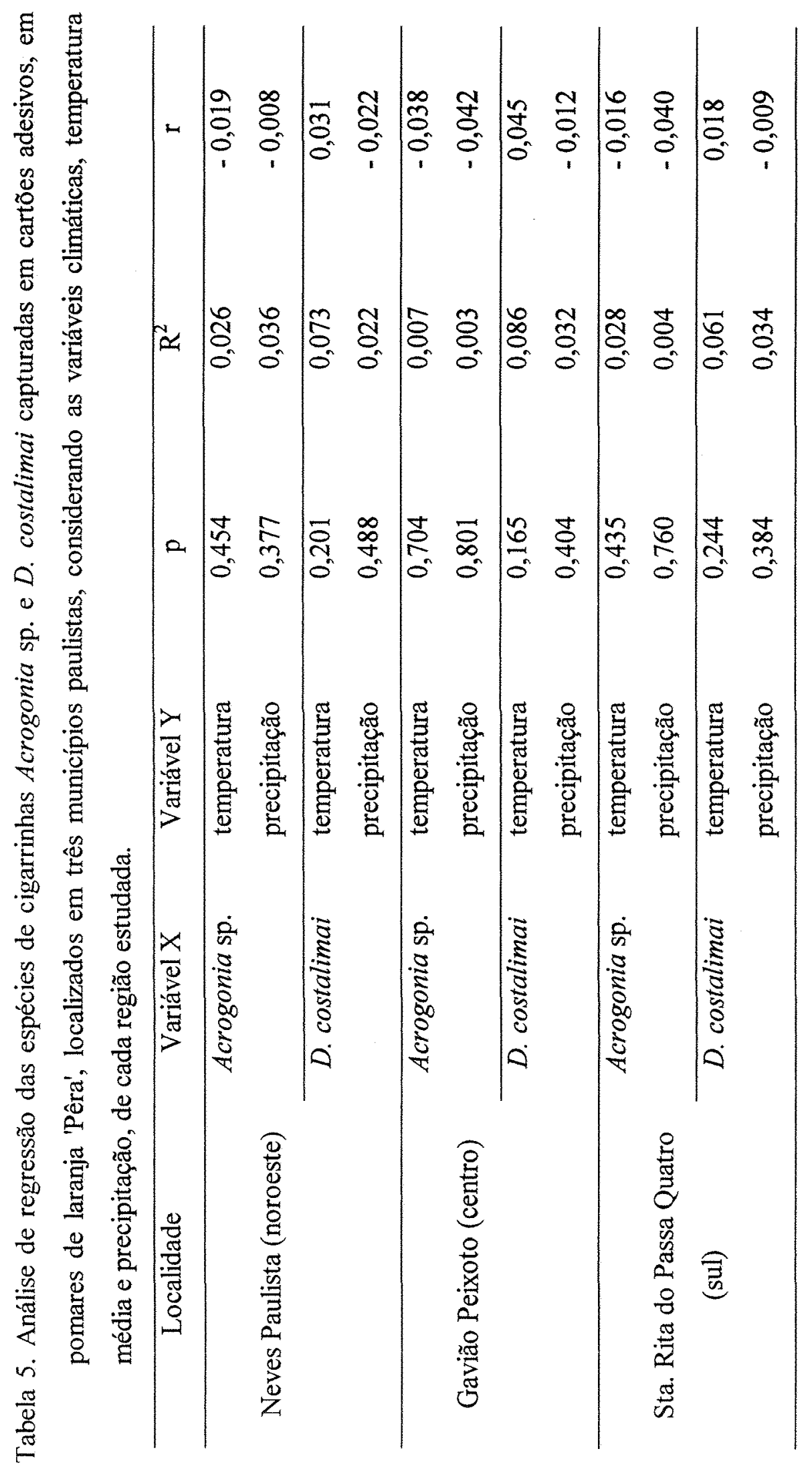




\subsection{Infectividade natural de cigarrinhas vetoras}

Os indivíduos testados foram capturados pelos dois métodos de amostragem, durante o período de dois anos, nos três pomares estudados. A infectividade natural das cigarrinhas vetoras, determinada pelo teste de DAS-ELISA indireto, foi baixa. Apenas 25 de 595 cigarrinhas testadas tiveram valores de absorbância duas vezes maiores que os controles negativos, correspondendo a uma infectividade natural de 4,2\% (Tabela 6). As espécies de cigarrinhas que se mostraram infectivas foram: Acrogonia sp., B. xanthophis, D. costalimai, H. ignorata, $P$. corniculata e $S$. grossa, com taxas de infectividade de $6,3 \%$, $2,6 \%, 4,8 \%, 6,2 \%, 14,3 \%$ e $8,3 \%$, respectivamente. As três últimas foram testadas em baixa quantidade ( $<20$ indivíduos), o que pode ter superestimado ou subestimado sua infectividade natural em relação às demais espécies.

No pomar da região noroeste, as espécies Acrogonia sp., D. costalimai e $P$. corniculata apresentaram infectividade natural de 4\%, 6,7\% e 14,3\%, respectivamente (Tabela 6). Já no pomar da região central, apenas a espécie Acrogonia sp. mostrou-se infectiva $(7,7 \%)$. No pomar localizado na região sul foram infectivas as espécies Acrogonia sp., B. xanthophis, D. costaimai, $H$. ignorata e $S$. grossa, com valores de 6,7\%, 6,4\%, $5,1 \%, 11,1 \%$ e $8,3 \%$, respectivamente. Somando-se os indivíduos de todas as espécies vetoras capturadas, foram observados valores de infectividade natural de 3,6\%,2\% e 4,8\%, respectivamente, para os pomares das regiões noroeste, central e sul do Estado de São Paulo (Figura 7).

Para deteç̧ão de $X$. fastidiosa pelo método de DAS-ELISA, o limite mínimo de população bacteriana é de $10^{4} \mathrm{UFC} / \mathrm{mL}$ (Minsavage et al., 1994). Desta forma, algumas cigarrinhas que apresentavam populações de $X$ fastidiosa abaixo desse limite possivelmente não apresentaram resposta positiva, ou seja, valores de absorbância pelo menos duas vezes superiores aos controles negativos. 
Tabela 6. Infectividade natural de cigarrinhas vetoras capturadas por cartões adesivos e plantas iscas em três pomares do Estado de São Paulo, no período de agosto/98 a setembro/00.

\begin{tabular}{|c|c|c|c|c|}
\hline Localidade & Espécie & $\begin{array}{c}\mathrm{N}^{\circ} \mathrm{de} \\
\text { indivíduos } \\
\text { testados }\end{array}$ & $\begin{array}{c}\mathrm{N}^{\circ} \text { de } \\
\text { indivíduos } \\
\text { infectivos }\end{array}$ & $\begin{array}{c}\% \text { de } \\
\text { indivíduos } \\
\text { infectivos }\end{array}$ \\
\hline \multirow{8}{*}{ Neves Paulista } & Acrogonia sp. & 25 & 1 & 4 \\
\hline & B. xanthophis & 27 & 0 & 0 \\
\hline & D. costalimai & 15 & 1 & 6,7 \\
\hline & F. trivittata & 1 & 0 & 0 \\
\hline & H. ignorata & 3 & 0 & 0 \\
\hline & M. leucomelas & 2 & 0 & 0 \\
\hline & O. facialis & 3 & 0 & 0 \\
\hline & P. corniculata & 7 & 1 & 14,3 \\
\hline \multirow{6}{*}{ Gavião Peixoto } & Acrogonia sp. & 26 & 2 & 7,7 \\
\hline & B. xanthophis & 18 & 0 & 0 \\
\hline & D. costalimai & 22 & 0 & 0 \\
\hline & F. trivittata & 7 & 0 & 0 \\
\hline & H. ignorata & 4 & 0 & 0 \\
\hline & O. facialis & 23 & 0 & 0 \\
\hline \multirow{9}{*}{$\begin{array}{l}\text { Sta. Rita do } \\
\text { Passa Quatro }\end{array}$} & Acrogonia sp. & 60 & 4 & 6,7 \\
\hline & B. xanthophis & 31 & 2 & 6,4 \\
\hline & D. costalimai & 233 & 12 & 5,1 \\
\hline & F. trivittata & 16 & 0 & 0 \\
\hline & H. ignorata & 9 & 1 & 11,1 \\
\hline & M. leucomelas & 2 & 0 & 0 \\
\hline & O. facialis & 46 & 0 & 0 \\
\hline & P. gratiosa & 3 & 0 & 0 \\
\hline & S. grossa & 12 & 1 & 8,3 \\
\hline \multirow{11}{*}{ Total } & Acrogonia sp. & 111 & 7 & 6,3 \\
\hline & B. xanthophis & 76 & 2 & 2,6 \\
\hline & D. costalimai & 270 & 13 & 4,8 \\
\hline & F. trivittata & 24 & 0 & 0 \\
\hline & H. ignorata & 16 & 1 & 6,2 \\
\hline & M. leucomelas & 4 & 0 & 0 \\
\hline & O. facialis & 72 & 0 & 0 \\
\hline & P. gratiosa & 3 & 0 & 0 \\
\hline & P. corniculata & 7 & 1 & 14,3 \\
\hline & S. grossa & 12 & 1 & 8,3 \\
\hline & & 595 & 25 & 4,2 \\
\hline
\end{tabular}


A despeito da sensitividade do teste de ELISA, as baixas taxas de infectividade natural observadas poderiam ser explicadas por uma baixa eficiência de aquisição do patógeno pelo vetor, possivelmente decorrentes da população relativamente baixa de $X$. fastidiosa em citros (Almeida, 1999) em relação a outras plantas hospedeiras, especialmente videira, na qual a aquisição e posterior transmissão por um vetor eficiente ocorreram após a multiplicação da bactéria a uma população de $10^{4} \mathrm{UFC} / \mathrm{g}$ de tecido (Hill \& Purcell, 1997).

Acredita-se que a baixa eficiência de transmissão de $X$. fastidiosa, pelas cigarrinhas identificadas como vetoras em citros, esteja relacionada com a baixa eficiência de aquisição e/ou inoculação do patógeno (Lopes, 1999). De acordo com Hopkins (1989) e Purcell \& Finlay (1979), os vetores adultos da estirpe de $X$. fastidiosa que causa a doença de Pierce da videira nos Estados Unidos, após adquirirem a bactéria, podem transmiti-la imediatamente para plantas sadias e continuar transmitindo eficientemente até o final de suas vidas. Porém, esses vetores apresentam eficiência de aquisição e transmissão superiores a $90 \%$, diferentemente do que ocorre em citros no Brasil, onde essa eficiência é baixa (Krügner et al., 1998).

Os dados de indivíduos infectivos de todas as espécies e épocas foram agrupados trimestralmente, visando-se identificar a que época do ano em que ocorre maior probabilidade de aquisição da bactéria (Figura 8). Não houve diferença estatística significativa entre as estações do ano na proporção de indivíduos positivos para $X$. fastidiosa $\left(\mathrm{X}^{2}=5,837 ; \mathrm{P}=0,12\right)$. Porém, houve uma tendência de menor infectividade natural no inverno e primavera (Figura 8). A elevação da taxa de infectividade natural no verão parece ser consistente com a ocorrência de sintomas de CVC no campo, já que a incidência e severidade da doença aumentam a partir da primavera (Palazzo \& Carvalho, 1992; Laranjeira, 1997). O estresse hídrico não afeta de forma significativa a concentração de nutrientes (Andersen et al., 1995). Entretanto, constatou-se que a tensão gerada no xilema afeta a alimentação das cigarrinhas durante o dia (Andersen et al., 1992). 


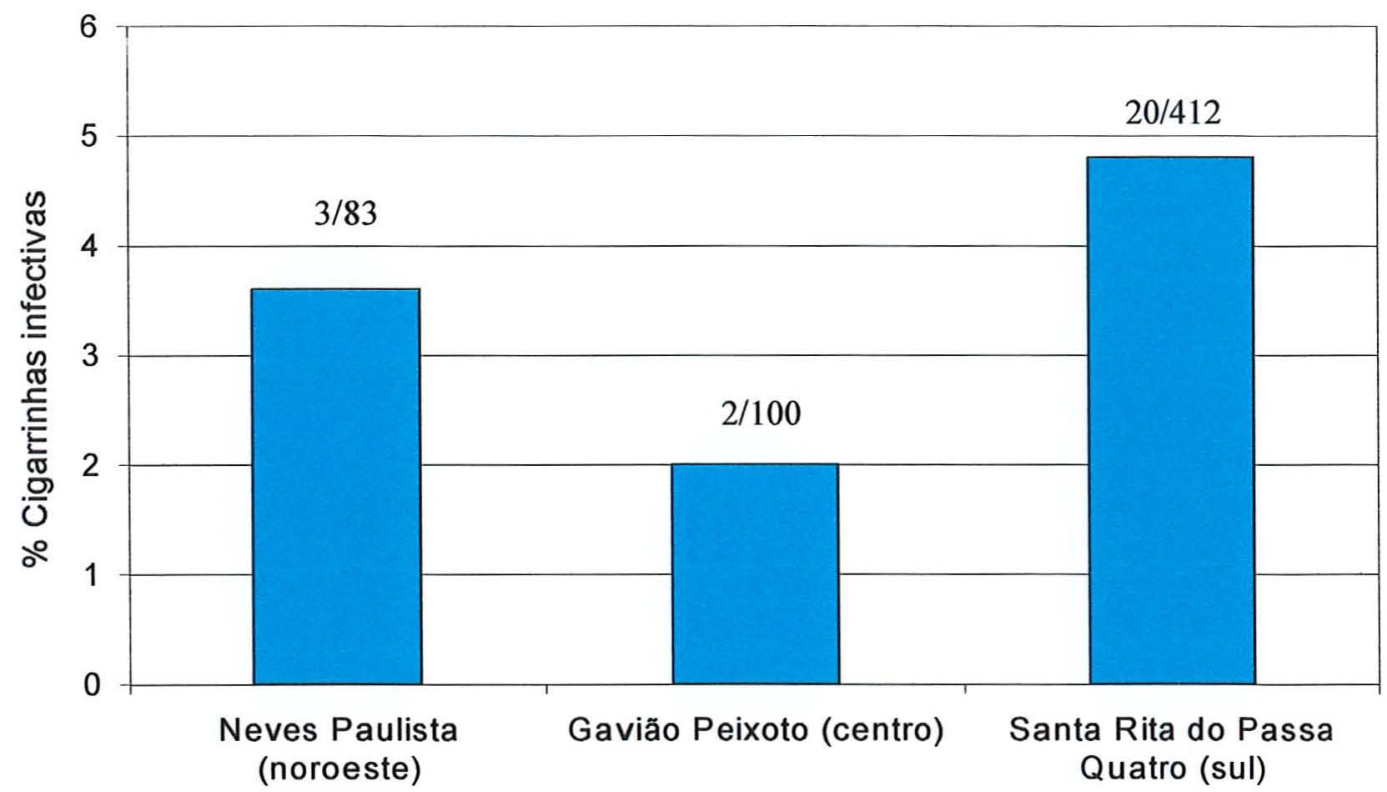

Figura 7. Infectividade natural de cigarrinhas vetoras capturadas por cartões adesivos e plantas iscas em pomares paulistas de laranja 'Pêra', localizados nos municípios de Neves Paulista, Gavião Peixoto e Santa Rita do Passa Quatro, no período de agosto/98 a setembro/00.

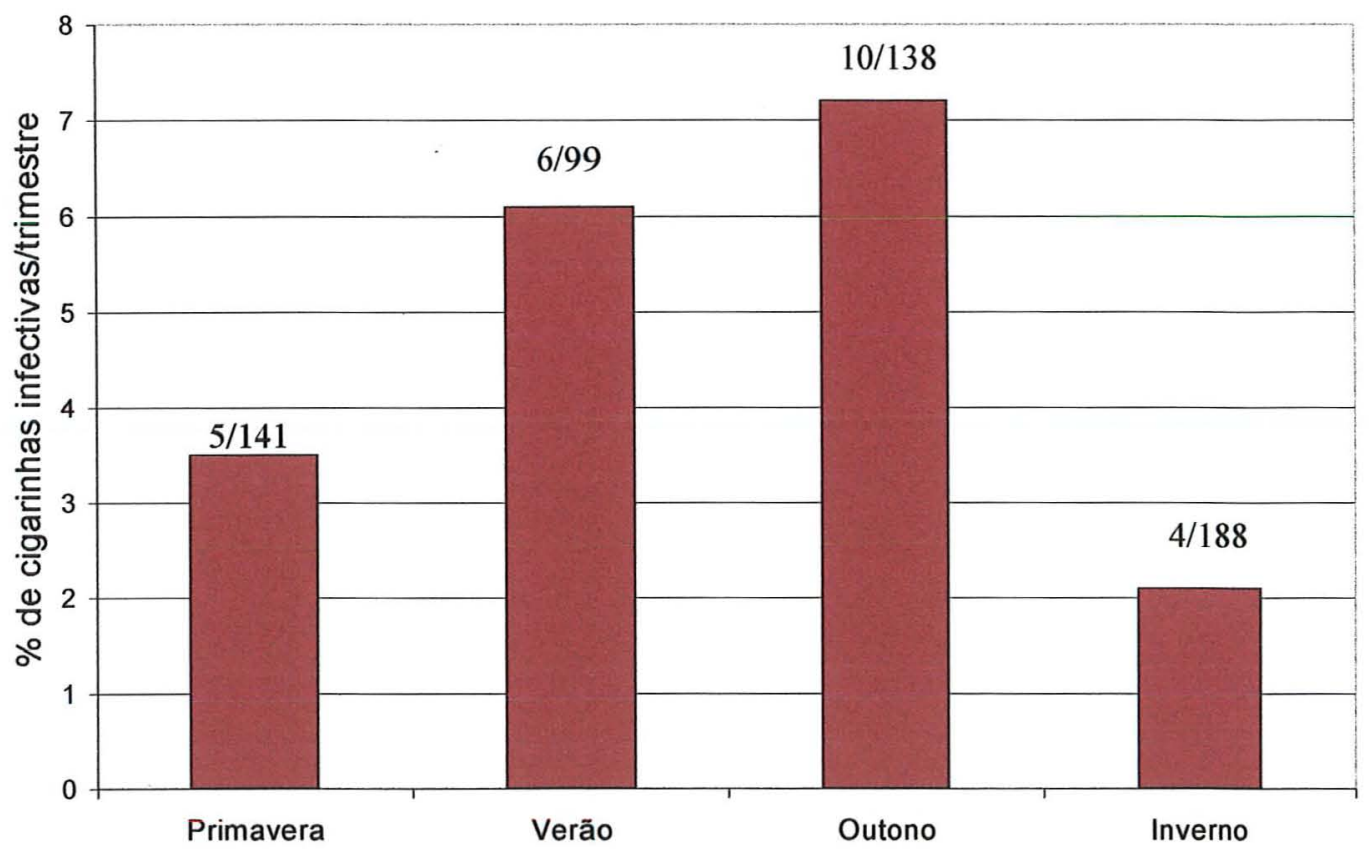

Figura 8. Infectividade natural de cigarrinhas vetoras capturadas por cartões adesivos e plantas-iscas, em pomares paulistas de laranja 'Pêra', localizados nos municípios de Neves Paulista, Gavião Peixoto e Santa Rita do Passa Quatro, nas diferentes estações do ano, no período de agosto/98 a setembro/00. 


\subsection{Flutuação populacional da bactéria na planta cítrica}

Testes preliminares de isolamento de $X$. fastidiosa a partir de amostras de folhas sintomáticas de citros, sem diluição, apresentaram alta taxa de contaminação (70 a 90\%). Com base nesses dados, foi feita uma diluição de $10 \mathrm{X}$ das amostras das folhas sintomáticas provenientes do campo, a qual mostrou-se satisfatória na redução do percentual de contaminação, com eficiência superior a $70 \%$, sem alteração significativa na sensibilidade do teste (Tabela 7).

Tabela 7. População de células viáveis de Xylella fastidiosa em folhas sintomáticas de árvores de laranja 'Pêra' com sintomas de CVC em diferentes áreas do Estado de São Paulo, no período de fevereiro/1999 a junho/99.

\begin{tabular}{|c|c|c|c|c|c|}
\hline \multirow[b]{2}{*}{ Localidades } & \multirow[b]{2}{*}{$\begin{array}{l}N^{\circ} \text { de amostras } \\
\text { foliares }\end{array}$} & \multicolumn{4}{|c|}{ Porcentagem de amostras testadas } \\
\hline & & Positivas & Negativas & Contaminadas & $\begin{array}{c}\text { População } \\
\text { média }^{1} \\
(\log \text { CFU/g) }\end{array}$ \\
\hline Neves Paulista (SP) & 51 & 80,4 & 7,8 & 11,8 & $5,91 \pm 0,10 \mathrm{a}^{2}$ \\
\hline Gavião Peixoto (SP) & 47 & 72,3 & 19,1 & 8,5 & $5,77 \pm 0,11 \mathrm{a}$ \\
\hline $\begin{array}{l}\text { Sta. Rita do Passa } \\
\text { Quatro (SP) }\end{array}$ & 45 & 71,1 & 11,1 & 17,8 & $5,56 \pm 0,14 \mathrm{a}$ \\
\hline $\begin{array}{l}\text { Todas as áreas } \\
\text { combinadas }\end{array}$ & 143 & 74,8 & 12,6 & 12,6 & $5,76 \pm 0,07$ \\
\hline
\end{tabular}

Amostras de colônias de todos os isolados obtidos em meio de cultura foram positivas em microscopia óptica, DAS-ELISA indireto ou PCR. Nenhuma colônia foi recuperada das folhas sadias (controles negativos). Os contaminantes normalmente apareceram entre 2 e 3 dias após o plaqueamento das suspensões.

De todas as amostras testadas no período de fevereiro a junho de 1999, não foi observada diferença significativa nas populações de $X$. fastidiosa. A população média total 
foi de 5,76 $\pm 0,07 \log$ UFC/g de tecido, de 143 folhas sintomáticas avaliadas. Parte das amostras (7,8 a 19,1\%) não apresentou resultados positivos para o isolamento da bactéria $X$. fastidiosa, sugerindo que a população de bactéria viável nessas folhas poderia ser menor que $3 \log$ UFC/g. Esse valor corresponde ao limite teórico para esse método de plaqueamento com diluição de 10 vezes.

As populações de células cultiváveis de $X$. fastidiosa, em nervuras centrais de folhas de laranja doce com sintomas de CVC, foram $10^{2}$ a $10^{3}$ vezes mais baixas que em videiras com a doença de Pierce, mas foram similares àquelas detectadas em alguns hospedeiros assintomáticos, nos quais as estirpes de $X$. fastidiosa de Pierce são sistêmicas, como blackberry (Hill \& Purcell, 1995), periwinkle, French broom, elderberry, e outros (Purcell \& Saunders, 1999). Exames de microscopia em nervuras centrais revelaram a presença de $X$. fastidiosa em células do xilema (Chagas et al., 1992; Mizubuti et al., 1994), o que também é observado em videiras com a doença de Pierce (Hopkins \& Mollenhauer,1973). Bloqueios crônicos de água pelas oclusões bacterianas nos vasos do xilema parecem causar sintomas da doença de Pierce (Goodwin et al., 1988). O xilema de videiras e outras plantas hospedeiras, apresentam dezenove aminoácidos, sete ácidos orgânicos, três ou quatro açúcares, amônia, nitrato, macro e microelementos, sendo a glutamina o principal composto nitrogenado presente nesse vaso (Andersen \& Brodbeck, 1989; Andersen et al., 1989), a qual é uma importante fonte nutricional para a bactéria, sendo exigida em meios de cultura.

A média populacional de $X$. fastidiosa no interior de plantas cítricas sintomáticas do pomar de Neves Paulista, foi de 5,56 $\pm 0,14 \mathrm{log}$ UFC/g/mL (Tabela 7). Correlacionando os resultados de população bacteriana, obtidos no período de março de 1999 a julho de 2000, com os dados climáticos da região, observou-se uma tendência de aumentos populacionais nos meses mais frios e com menores taxas pluviométricas (Figura 9). O contrário foi observado nos meses mais quentes e chuvosos.

Em Gavião Peixoto a população bacteriana média foi de $5,77 \pm 0,10 \log \mathrm{UFC} / \mathrm{g} / \mathrm{mL}$ (Tabela 7). Como observado no pomar da região noroeste, a população tendeu a ser maior nos meses mais frios e menos chuvosos (Figura 10). 

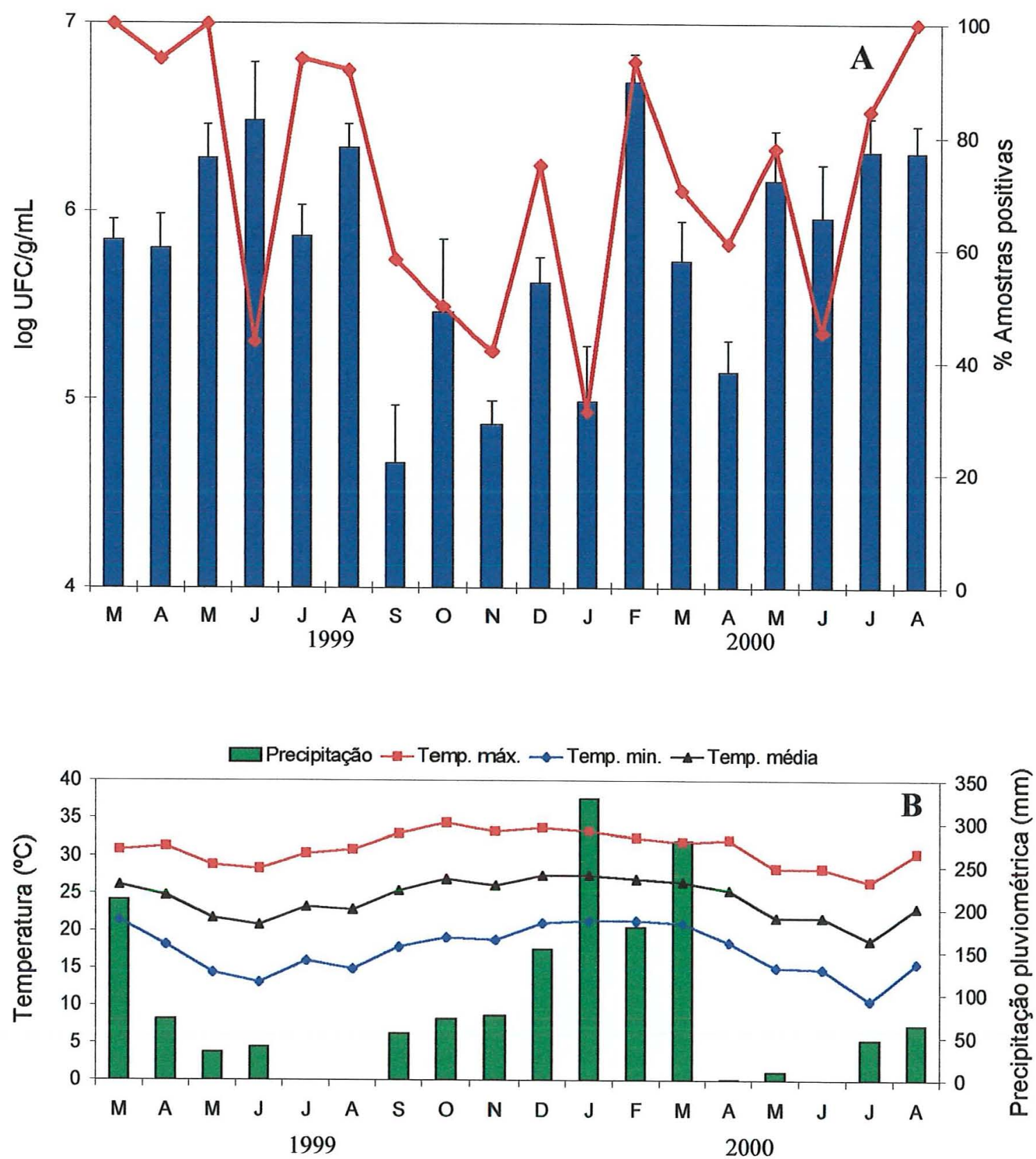

Figura 9. A) Flutuação populacional de $X$. fastidiosa em plantas de laranja 'Pêra', no município de Neves Paulista (SP), no período de março/1999 a agosto/2000. B) Dados de precipitação pluviométrica e temperatura (médias) registrados para o período. 

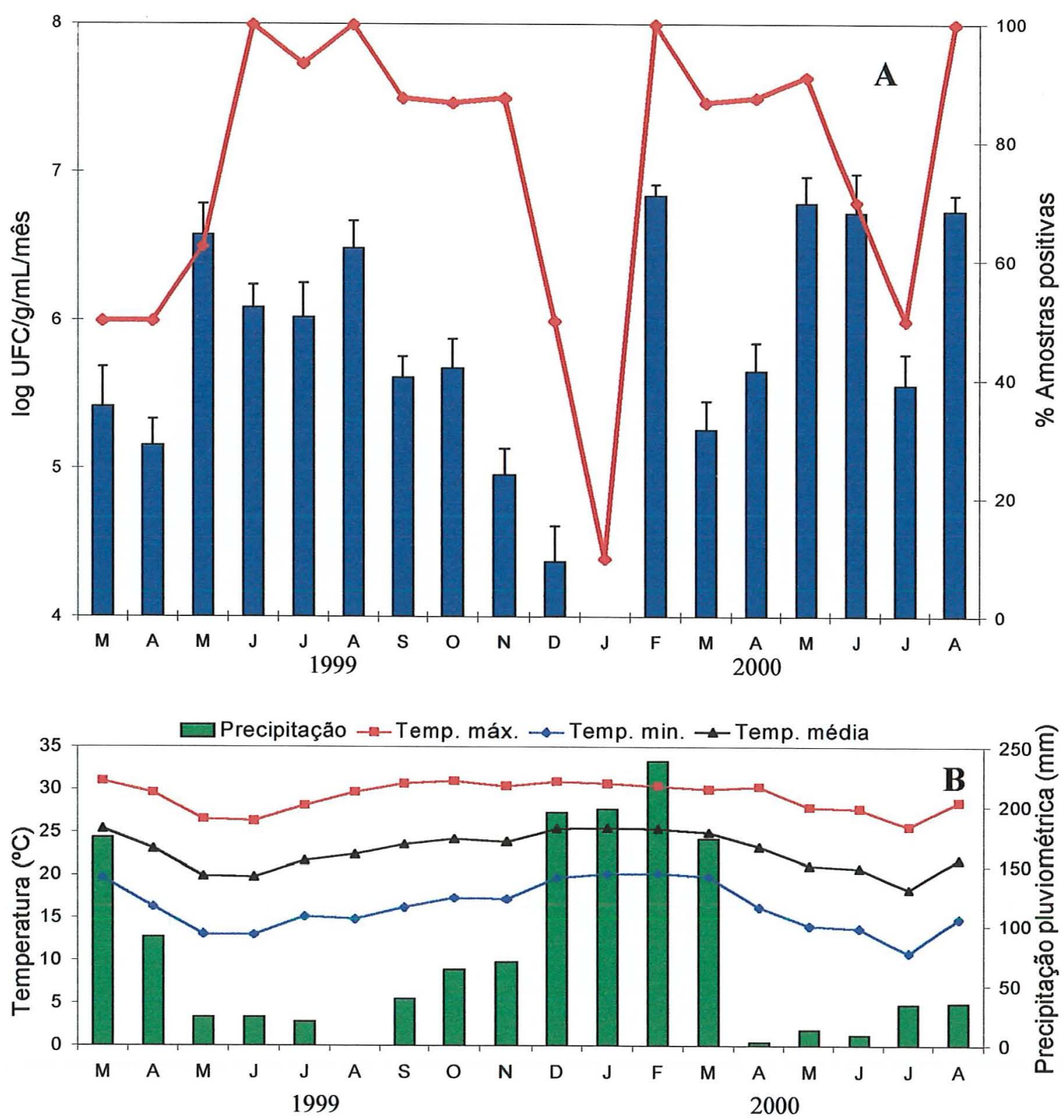

Figura 10. A) Flutuação populacional de $X$. fastidiosa em plantas sintomáticas de laranja 'Pêra', no município de Gavião Peixoto (SP), no período de março/1999 a agosto/2000. B) Dados de precipitação pluviométrica e de temperatura (médias) registrados para o período. 
Em Santa Rita do Passa Quatro a população média foi de 5,56 $\pm 0,14 \log$ UFC/g/mL (Tabela 7). Apesar de não ter sido possível detectar a população bacteriana em alguns meses (Figura 11), observou-se uma tendência de acréscimo populacional nos meses de outono e inverno e decréscimo nos meses de primavera e verão, como foi observado nos pomares das regiões noroeste e central (Figuras 9 e 10).

A média populacional de $X$. fastidiosa não foi diferente estatisticamente nos pomares estudados, no período de fevereiro a junho de 1999 (Tabela 7). A tendência de aumento populacional no outono-inverno e redução na primavera-verão (Figuras 9, $10 \mathrm{e}$ 11), também foi observada por Chang \& Yonce (1987), que detectaram menores índices de isolamento de $X$ fastidiosa em ameixeira na primavera, com aumento no outono. $\mathrm{O}$ mesmo fato foi observado por Leite et al. (1997), estudando a flutuação populacional de $X$. fastidiosa em ameixeiras, verificando maiores índices populacionais no mês de maio, e menores no mês de novembro, em uma variedade suscetível à escaldadura das folhas, tanto no isolamento em meio de cultura BCYE quanto em testes sorológicos de DAS-ELISA. A sazonalidade de estirpes da bactéria em videira foi observada por Hopins \& Thompson (1984), não sendo detectada na primavera, atingindo picos no verão e permanecendo detectável até o outono. De acordo com Leite et al. (1997) o aumento da população bacteriana nos tecidos das plantas hospedeiras, em geral, normalmente coincide com o aparecimento de sintomas da doença.

A capacidade da bactéria de se movimentar e se multiplicar no interior de plantas hospedeiras está relacionada com a virulência das estirpes (Hopkins, 1985), clima (Purcell, 1977; Hopkins \& Thompson, 1984), tempo de acúmulo (Fry \& Milholand, 1990; Hill \& Purcell, 1995), espécie hospedeira (Hill \& Purcell, 1995) e mudanças fisiológicas na planta após a infecção (Hopkins \& Thompson, 1984; Queiroz-voltan \& Paradela Filho, 1999).

Hopkins \& Thompson (1984) verificaram que a bactéria não se desenvolveu em tecidos jovens e em pleno desenvolvimento, o que também foi verificado por Chang \& Yonce (1987) e Hopkins (1989). Queiroz-voltan \& Paradela Filho (1999) constataram que ramos com sintomas de deficiência de zinco apresentaram uma concentração maior de cristais de hesperidina, observados ainda em plantas com sintomas de CVC no interior das células do floema e do xilema de folhas, caule e frutos e, algumas vezes, das glândulas 

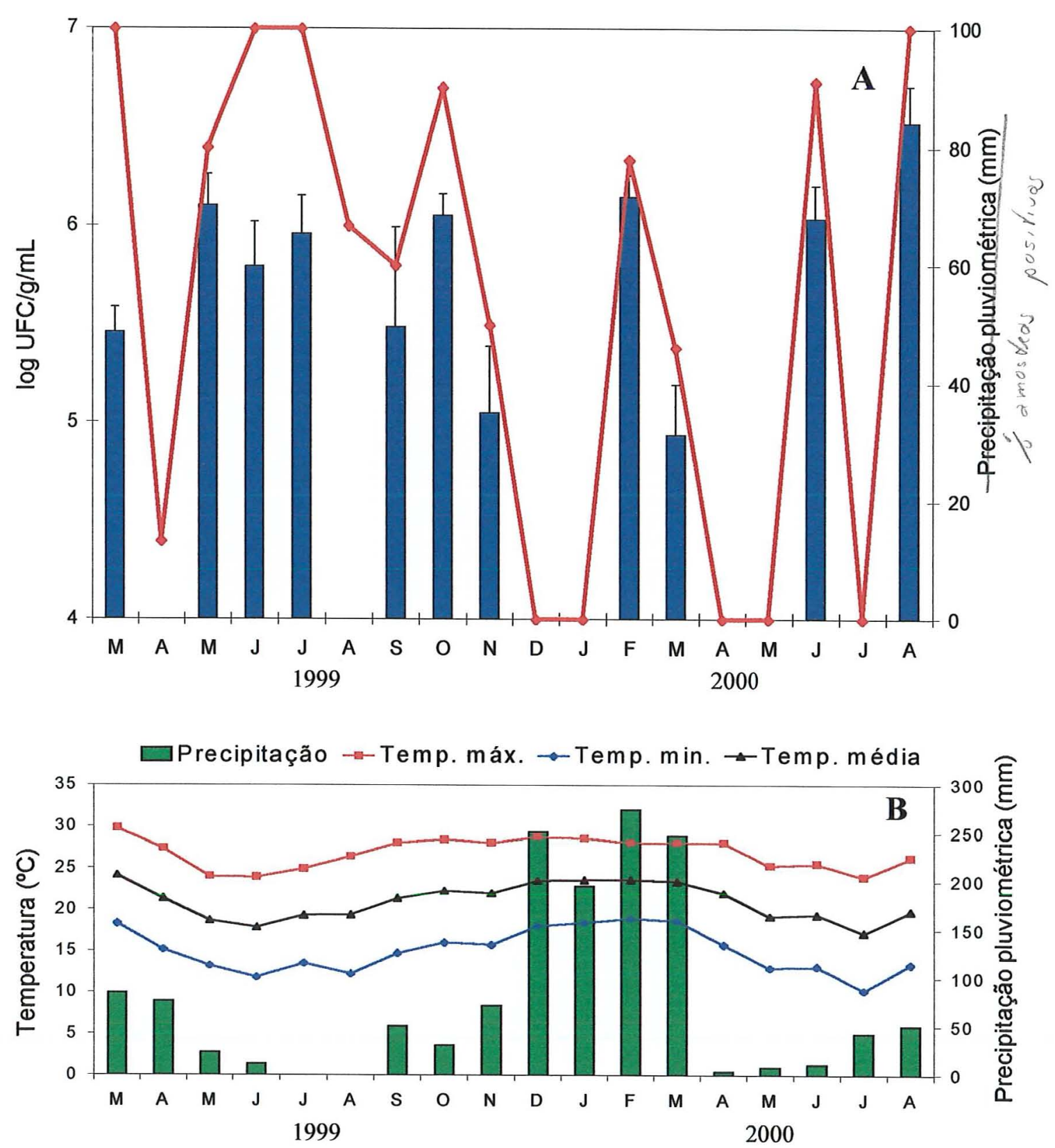

Figura 11. A) Flutuação populacional de $X$. fastidiosa em plantas de laranja 'Pêra', no município de Santa Rita do Passa Quatro (SP), no período de março/1999 a agosto/2000. B) Dados de precipitação pluviométrica e temperatura (médias) registrados para o período. 
secretoras lisígenas, levantando a hipótese de que a bactéria, além de dificultar o fluxo de água através da planta, também entre em competição por nutrientes, resultando num desbalanço nutricional e hormonal, principalmente em situações de estresse de um ou mais fatores ambientais. $\mathrm{O}$ zinco, micronutriente encontrado em baixas concentrações em plantas sintomáticas, é essencial para a síntese do triptofano (Varner \& Ho, 1976), que por sua vez é o precursor do ácido endolacético que apresenta como um de seus papéis a expansão celular. Além disso, também se acentuam, após a infecção pela bactéria, a presença de clorose, altos níveis de prolina, ácido abscísico, e aumento na resistência estomática, que são fatores associados à senescência foliar (Goodwin et al., 1988; Machado et al., 1994). Hopkins (1985) sugeriu que as substâncias que aceleram a maturidade e a senescência da planta favorecem a multiplicação bacteriana, considerando que substâncias que retardam podem prevenir ou reduzir a população de $X$. fastidiosa.

Com base nesses trabalhos, pode-se extrapolar para os resultados obtidos nesse experimento, que a maior população bacteriana obtida nos meses mais frios e menos chuvosos esteja associada à baixa concentração ou translocação de substâncias que favoreçam o crescimento de tecidos jovens e em contrapartida, à maior concentração de substâncias promotoras de maturidade e senescência das plantas. Nesse período são característicos os sintomas visuais nas plantas com CVC (Quando, 1997).

\subsection{Efeito da época de inoculação na sobrevivência de $X$. fastidiosa em árvores cítricas}

\subsubsection{Inoculações mecânicas}

As avaliações realizadas em amostras de folhas retiradas de ramos inoculados tanto no pomar localizado na região noroeste quanto na região sul, após 30, 60, 90 e 120 dias da inoculação, apresentaram uma baixa taxa de recuperação de $X$. fastidiosa (Tabela 8). Das quatro inoculações realizadas, a que apresentou maiores proporções de ramos positivos, ao longo das avaliações mensais de ramos inoculados, foi aquela realizada no mês de dezembro (final da primavera) para as duas localidades (Tabela 8). 


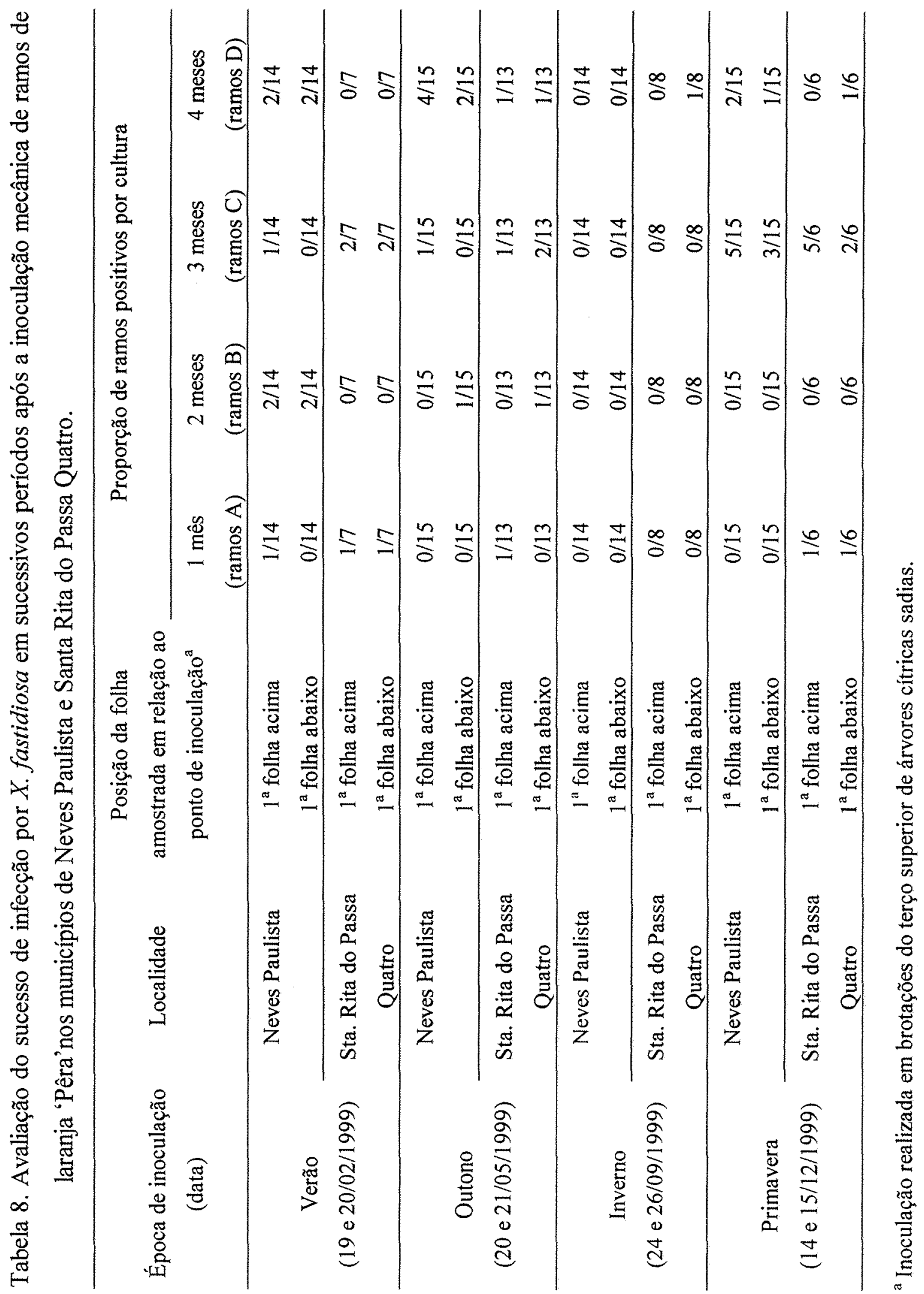


As amostras retiradas após a poda dos ramos inoculados, passados 5 meses da inoculação, apresentaram resposta positiva à presença de $X$. fastidiosa por isolamento em meio de cultura e por DAS-ELISA (Tabelas 9 e 10). Os testes de DAS-ELISA permitiram maximizar as chances de detecção da bactéria, observando-se que, normalmente, a proporção de amostras positivas foi ligeiramente maior por esse método de detecção do que por cultura. Com base nessas observações, é fundamental salientar que o teste ELISA detecta tanto células bacterianas vivas quanto mortas, já o isolamento em meio de cultura, detecta apenas células bacterianas viáveis presentes em cada amostra.

Houve diferença estatística significativa na proporção de ramos positivos entre as épocas de inoculação, para as amostras do pomar da região noroeste, analisando-se os dados de cultura, DAS-ELISA e de ambos métodos conjuntamente (Tabela 9). No pomar da região sul, entretanto, houve diferença estatística na proporção de ramos positivos entre épocas de inoculação apenas para o teste de cultura (Tabela 10). Comparações entre datas de inoculação envolvendo os resultados de DAS-ELISA ou de DAS-ELISA+cultura não indicaram diferenças significativas em Santa Rita do Passa Quatro.

As análises estatísticas indicaram, portanto, uma tendência de maior recuperação de células viáveis de $X$. fastidiosa após as inoculações nos meses de dezembro e fevereiro em ambas as localidades. No caso de Santa Rita do Passa Quatro, a ausência de diferença estatística por ELISA sugere que as infecções iniciaram com taxa de sucesso semelhante nas diferentes épocas de inoculação; porém, a diferença por cultura sugere que a sobrevivência dessas infecções foi maior nas inoculações realizadas em dezembro e fevereiro (Tabela 10). 
Tabela 9. Avaliação do sucesso de infecção por $X$. fastidiosa após 5 meses da inoculação mecânica ${ }^{a}$ de ramos cítricos de laranja 'Pêra', no município de Neves Paulista (SP).

\begin{tabular}{cccc}
\hline $\begin{array}{c}\text { Época de inoculação } \\
\text { (data) }\end{array}$ & Cultura $^{\mathrm{b}}$ & DAS-ELISA $^{\mathrm{c}}$ & Cultura + DAS-ELISA \\
\cline { 2 - 4 } & $12 / 56$ & $4 / 49$ & $12 / 56$ \\
\hline Fev/99 (20/02/99) & $4 / 60$ & $0 / 44$ & $4 / 60$ \\
Mai/99 (20/05/99) & $0 / 56$ & $5 / 56$ & $5 / 56$ \\
Set/99 (24/09/99) & $7 / 60$ & $9 / 52$ & $15 / 60$ \\
Dez/99 (14/12/99) & 16,067 & 11,011 & 11,048 \\
\hline$X^{2}$ & 0,001 & 0,012 & 0,010
\end{tabular}

a Inoculação de ramos cítricos sadios pipetando-se uma gota de $5 \mu \mathrm{L}$ de suspensão bacteriana e transpassando-a com alfinete entomológico $n^{0} 0$ até a perfuração do ramo;

b Amostras de 2 folhas coletadas $3 \mathrm{~cm}$ acima e abaixo do ponto de inoculação de todos os ramos inoculados;

${ }^{c}$ Amostras de 2 folhas coletadas $10 \mathrm{~cm}$ acima e abaixo do ponto de inoculação dos ramos inoculados (algumas amostras foram avaliadas apenas por cultura).

Tabela 10. Avaliação do sucesso de infecção por $X$. fastidiosa após 5 meses da inoculação mecânica' de ramos cítricos de laranja 'Pêra', no município de Santa Rita do Passa Quatro (SP).

\begin{tabular}{cccc}
\hline \multirow{2}{*}{$\begin{array}{c}\text { Época de inoculação } \\
\text { (data })\end{array}$} & Cultura $^{b}$ & DAS-ELISA $^{c}$ & Cultura + DAS-ELISA $^{\text {Proporção de ramos positivos }}$ \\
\cline { 2 - 4 } & $3 / 28$ & $2 / 24$ & $5 / 28$ \\
Fev/99 (19/02/99) & $2 / 52$ & $7 / 51$ & $9 / 52$ \\
Mai/99 (21/05/99) & $0 / 32$ & $4 / 31$ & $4 / 32$ \\
Set/99 (26/09/99) & $9 / 24$ & $1 / 24$ & $9 / 24$ \\
\hline Dez/99 (15/12/99) & 25,255 & 4,711 & 6,066 \\
\hline$X^{2}$ & 0,001 & 0,194 & 0,108
\end{tabular}

a Inoculação de ramos cítricos sadios pipetando-se uma gota de $5 \mu \mathrm{L}$ de suspensão bacteriana e transpassando-a com alfinete entomológico $n^{0} 0$ até a perfuração do ramo;

b Amostras de 2 folhas coletadas $3 \mathrm{~cm}$ acima e abaixo do ponto de inoculação de todos os ramos inoculados;

${ }^{c}$ Amostras de 2 folhas coletadas $10 \mathrm{~cm}$ acima e abaixo do ponto de inoculação dos ramos inoculados (algumas amostras foram avaliadas apenas por cultura). 
Segundo Esaú (1948) e Purcell (1977), X. fastidiosa necessita de um determinado tempo para se multiplicar no interior de plantas hospedeiras, sendo que essa multiplicação pode ser afetada pelo clima de inverno. Assim, existem algumas considerações que devem ser feitas e que podem explicar a baixa recuperação de $X$. fastidiosa das amostras de ramos inoculados durante o inverno, sob condições de campo. Se as baixas temperaturas de inverno de fato retardam o crescimento bacteriano, o período de 5 meses após a inoculação, para a avaliação final dos ramos inoculados, pode ter sido muito curto para que houvesse multiplicação bacteriana suficiente para detecção pelos testes empregados. Pode ainda ter ocorrido morte da bactéria algum tempo depois da inoculação por condições adversas à sua multiplicação, como baixa concentração de nutrientes na seiva do xilema (Purcell \& Hopkins, 1996), e baixa translocação desses nutrientes em períodos mais secos, como ocorre no inverno no Estado de São Paulo, desfavorecendo seu estabelecimento em infecções iniciais.

\subsubsection{Inoculação por cigarrinhas vetoras}

Após 8 meses da inoculação de ramos sadios de citros utilizando-se cigarrinhas submetidas previamente a um PAA de $48 \mathrm{~h}$ em planta-fonte de $X$. fastidiosa, foi observada uma proporção muito baixa de ramos infectados (Tabela 11). Apenas dois ramos apresentaram resposta positiva na detecção da bactéria por isolamento em meio de cultura e um ramo utilizando-se o teste sorológico de DAS-ELISA indireto, que representaram apenas $6,5 \%$ do total de ramos inoculados nas diferentes épocas. Os ramos positivos corresponderam às inoculações realizadas com O. facialis (Tabela 11).

Observou-se, portanto, uma baixa eficiência de transmissão por cigarrinhas para ramos de árvores cítricas em condições de campo, o que impossibilitou uma análise comparativa do sucesso de inoculação por vetores em diferentes épocas do ano. As diferentes espécies de cigarrinhas vetoras variam quanto sua eficiência de transmissão (Severin, 1949). Krügner et al. (1998) e Lopes (1999) relataram uma baixa eficiência de aquisição e/ou transmissão de $X$. fastidiosa por cigarrinhas vetoras em mudas de citros, sob condições controladas. De todas as espécies vetoras de $X$. fastidiosa, $M$. leucomelas 
foi a que apresentou maior eficiência de transmissão, chegando a infectar $17 \%$ das plantas inoculadas, sendo que apenas um indivíduo foi confinado por planta-teste (Descobertos, 1999).

Tabela 11. Avaliação do sucesso de inoculação de $X$. fastidiosa por cigarrinhas infectivas $^{\mathrm{a}}$ no pomar de laranja 'Pêra' localizado no município paulista de Gavião Peixoto, em quatro diferentes épocas.

\begin{tabular}{|c|c|c|c|c|}
\hline \multirow[t]{2}{*}{ Época de inoculação } & \multirow[t]{2}{*}{ Espécie vetora } & \multirow{2}{*}{$\begin{array}{l}\mathrm{N}^{0} \text { de ramos } \\
\text { inoculados }\end{array}$} & \multicolumn{2}{|c|}{$\begin{array}{c}\mathrm{N}^{0} \text { infecções positivas para } X \text {. } \\
\text { fastidiosa }\end{array}$} \\
\hline & & & Cultura & DAS-ELISA \\
\hline $20 / 04 / 99$ a $22 / 04 / 99$ & $\begin{array}{l}\text { Oncometopia } \\
\text { facialis }\end{array}$ & 10 & $0 / 10$ & $1 / 10$ \\
\hline $10 / 06 / 99$ a $12 / 06 / 99$ & $\begin{array}{l}\text { Oncometopia } \\
\text { facialis }\end{array}$ & 17 & $2 / 17$ & $0 / 17$ \\
\hline $17 / 09 / 99$ a $19 / 09 / 99$ & $\begin{array}{c}\text { Dilobopterus } \\
\text { costalimai }\end{array}$ & 14 & $0 / 14$ & $0 / 14$ \\
\hline $14 / 12 / 99$ a $16 / 12 / 99$ & $\begin{array}{l}\text { Dilobopterus } \\
\text { costalimai }\end{array}$ & 5 & $0 / 5$ & $0 / 15$ \\
\hline
\end{tabular}

Almeida (1999), estudando a eficiência de aquisição de $X$. fastidiosa por 27 indivíduos da espécie $D$. costalimai e 16 da espécie $B$. xanthophis, não detectou bactéria nos insetos por teste sorológico de ELISA e nem por cultura, após períodos de acesso à aquisição de 48 e 96 horas em plantas-fonte, demonstrando ser baixa a eficiência de aquisição da bactéria por cigarrinhas de citros. Em um segundo experimento, utilizando 225 cigarrinhas adultas das espécies $O$. facialis e $D$. costalimai em teste de inoculação de $X$. fastidiosa em citros, esse autor constatou que 20 estavam infectadas após isolamentos em meio de cultura e apenas uma em teste de DAS-ELISA. Mesmo assim, 
nenhuma planta-teste foi contaminada pela bactéria, indicando também uma baixa eficiência de inoculação desse patógeno.

Segundo Day (1952), a eficiência de um vetor pode estar relacionada com a freqüência com que a cigarrinha atinge os vasos do xilema em diferentes espécies de plantas hospedeiras e também com o modo e tempo de alimentação nessas plantas. Além disso, a bactéria não se encontra distribuída de maneira uniforme no interior dos vasos do xilema das plantas (Purcell, 1989; Purcell \& Hopkins, 1996). O local de alimentação nas plantas hospedeiras da bactéria também pode influenciar a eficiência de aquisição e/ou inoculação de diferentes espécies de cigarrinhas vetoras (Lopes, 1996). Portanto, baixa detecção de $X$. fastidiosa nos ramos inoculados por vetores neste estudo pode estar relacionada aos diversos fatores relatados.

\subsection{Considerações finais}

Baseando-se nos resultados obtidos nos experimentos de campo e em trabalhos de outros autores anteriormente citados, formulou-se uma hipótese na tentativa de explicar como funciona o patossistema nos pomares de citros. Sabe-se que vários fatores podem influenciar os picos populacionais de cigarrinhas vetoras de $X$. fastidiosa no campo, entre eles temperatura e precipitação pluviométrica (Roberto \& Yamamoto, 2000). Assim, picos populacionais dos vetores, de maneira geral, costumam ocorrer nos meses mais quentes e chuvosos, quando a probabilidade de transmissão da bactéria aumenta. O contrário foi observado com a população de bactérias em infecções já estabelecidas, que teve um aumento aparente nos meses mais frios e secos, podendo este incremento estar relacionado à presença de substâncias responsáveis pela maturação e senescência das plantas (Hopkins, 1985). Infecções pré-estabelecidas parecem levar vantagem em relação às infecções iniciais nessa época, provavelmente por algum fator de adaptação, fisiológico ou nutricional (Purcell, 1977; Chang \& Yonce, 1987; Hopkins, 1989). Alguns trabalhos relacionaram uma correlação negativa entre a multiplicação bacteriana e a presença de substâncias responsáveis pelo crescimento de tecidos (Hopkins \& Thompson, 1984; Chang \& Yonce, 1987; Hopkins, 1989). 
Experimentos de inoculação mecânica sugerem que a época do ano mais quente $\mathrm{e}$ chuvosa é mais favorável à infecção primária da bactéria, enquanto que a época mais fria e seca, aparentemente, parece ser menos favorável à sobrevivência de infecções iniciais de $X$. fastidiosa em ramos de árvores cítricas. Esse fato pode estar relacionado, hipoteticamente, à menor tensão no xilema e maior disponibilidade de água e nutrientes na época quente e chuvosa. Desse modo, pode-se supor que a maior chance de disseminação da doença ocorra na época do ano em que a temperatura começa a se elevar e a precipitação torna-se mais freqüente, que deve ocorrer, em anos com distribuição normal de chuvas, a partir de meados da primavera (outubro/novembro). Nesse período, o inóculo continua presente em altas quantidades no interior do xilema, a disponibilidade de água e nutrientes aumenta e a tensão nesses vasos cai. Além disso, ocorre um aumento no número de brotações nas plantas que, por sua vez, são atrativas às cigarrinhas, as quais passam a freqüentar o pomar mais ativamente. Portanto, a ocorrência dessas condições em pomares de laranja parece definir a época de maior probabilidade de inoculação de $X$. fastidiosa por vetores, em que medidas de controle devem ser reforçadas a fim de se reduzir a disseminação de $X$. fastidiosa para plantas sadias. 


\section{CONCLUSÕES}

- As plantas-iscas capturam cigarrinhas vetoras de Xylella fastidiosa em condições de campo, porém, em menor número que os cartões adesivos amarelos;

- Dilobopterus costalimai é a espécie vetora predominante no pomar da região sul, enquanto que Acrogonia sp. predomina nos pomares das regiões noroeste e central, baseando-se nas coletas com cartões adesivos amarelos;

- As espécies vetoras são capturadas por cartões adesivos nos pomares durante todo o ano;

- A infectividade natural dos vetores nos pomares estudados é baixa;

- A diluição de $10 X$, usada no isolamento primário de $X$ fastidiosa de amostras foliares provenientes de campo, reduz significativamente o percentual de contaminação em meio de cultura, proporcionando eficiência de isolamento superior a $70 \%$;

- A população de células cultiváveis de X. fastidiosa em folhas sintomáticas não varia entre árvores com CVC das regiões noroeste, central e sul do Estado de São Paulo; 
- A recuperação de células cultiváveis de X fastidiosa é maior em ramos cítricos inoculados mecanicamente nos meses de dezembro e fevereiro, em relação a ramos inoculados em maio e setembro;

- Inoculações por cigarrinhas em ramos de árvores cítricas no campo, após acesso à aquisição em mudas de citros infectadas com $X$. fastidiosa em casa de vegetação, são pouco eficientes; 


\section{REFERÊNCIAS BIBLIOGRÁFICAS}

ADLERZ, W.C.; HOPKINS, D.L. Natural infectivity of two sharpshooters vectors of Pierce's disease of grape in Florida. Journal of Ecomomic Entomolgy, v.72, n.6, p.916-919, 1979.

ALMEIDA, R.P.P. Multiplicação e movimentação de X. fastidiosa em mudas de Citrus sinensis e sua eficiência de aquisição e inoculação por vetores. Piracicaba, 1999. 57p. Dissertação (Mestrado) - Escola Superior de Agricultura "Luiz de Queiroz", Universidade de São Paulo.

ANDERSEN, P.C.; BROADBECK, B.V. Diurnal and temporal changes in the chemical profile of xylem exudate from Vitis rodundifolia. Physiologia Plantarum, v.75, p.63-70, 1989a.

ANDERSEN, P.C.; BROADBECK, B.V. Temperature and temperature preconditioning on flux and chemical composition of xylem exudate from muscadine grapevines. Journal of the American Society for Horticultural Science, v.114, n.3, p.440$444,1989 b$.

ANDERSEN, P.C.; BROADBECK, B.V.; MIZELL III, R.F. Metabolism of amino acids, organic acids and sugar extracted from the xylem fluid of four host plants byadult Homalodisca coagulata. Entomologia Experimentallis and Applicata, v.50, p.149-159, 1989. 
ANDERSEN, P.C.; BROADBECK, B.V.; MIZELL III, R.F. Feeding by the leafhooper, Homalodisca coagulata, in relation to xylem fuid chemistry and tension. Journal of Insect Physiology, v.38, n.8, p.611-622, 1992.

ANDERSEN, P.C.; BROADBECK, B.V.; MIZELL III, R.F. Diurnal variations in tension, osmolarity, and the composition of nitrogen and carbon assimilates in xylem fluid of Prunus persica, Vitis hybrid, and Pyrus communis. Journal of the American Society for Horticultural Science, v.120, n.4, p.600-606, 1995.

AYRES, A.J. Intensidade da clorose variegada dos citros em pomares comerciais de laranja do Estado de São Paulo e sul do triângulo mineiro. Jaboticabal, 2000. 59p. Dissertação (Mestrado) - Faculdade de Ciências Agrárias e Veterinárias, Universidade Estadual Paulista "Júlio de Mesquita Filho".

BERETTA, M.J.G.; DERRICK, K.S.; LEE, R.F.; HARAKAVA, R.; RICCI, A.P. Testes de diagnósticos para a deteç̧ão da bactéria Xylella fastidiosa em citros. Laranja, v.18, n.1, p.113-122, 1997.

BERISHA, B.; CHEN, Y.D.; ZHANG, G.Y.; XY, B.Y.; CHEN, T.A. Isolation of Pierce's disease bacteria from grapevines in Europe. European Journal of Plant Pathology, v.104, p.427-433, 1998.

BLUA, M.J.; PHILLIPS, P.A.; REDAK, R.A. A new sharpshooter threatens both crops and ornamentals. California Agriculture, v.53, n.2, p.22-25, 1999.

CARVALHO, M.L.V. Situação da clorose variegada dos citros e estratégias de controle. Fitopatologia Brasileira, v.21, p.328, 1996. /Resumo/ 
CARVALHO, S.A.; LARANJEIRA, F.F. Protótipo de viveiro de mudas certificadas e borbulheiras sob telado à prova de afídeos de Centro de Citricultura - IAC. Laranja, v.15, n.2, p.213-220, 1994.

CHAGAS, C.M.; ROSSETTI, V.; BERETTA, M.J.G. Eletron microscopy studies of a xylem-limited bacterium in sweet orange affected with citrus variegated chlorosis disease en Brazil. Journal of Phytopathology, v.134, p.300-312, 1992.

CHANG, C.J.; DONALDSON, R.C. Xylella fastidiosa: cultivation in chemically defined medium. Phytopathology, v.83, n.2, p. 192-194, 1993.

CHANG, C.J.; YONCE, C.E. Overwintering of plum leaf scald bacteria in infected trees. Annual Review of Phytopathology Society of Japan, v.53, p.345-353, 1987.

CHANG, C.J.; GARNIER, M.; ZREIK, L.; ROSSETTI, V.; BOVÉ, J.M. Culture and serological detection of the xylem-limited bacterium causing citrus variegated chlorosis and its identification as a strain of Xylella fastidiosa Current Microbiology, v.27, n.3, p.137-142, 1993.

CHERRY, R.H.; HOWARD, F.W. Sampling for adults of the planthopper Myndus crudus, a vector of lethae yellowing of palms. Tropical Pest Management, v.30, p.22-25, 1984.

COLETTA FILHO, H.D.; MACHADO, M.A.; TARGON, M.L.P.N. Deteç̧ão de Xylella fastidiosa da clorose variegada dos citros através de PCR. Fitopatologia Brasileira, v.21, p.343, 1996. Suplemento. /Apresentado ao 29. Congresso Brasileiro de Fitopatologia, Campo Grande, 1996 - Resumo/ 
CVC: sintomas estão mais graves. Revista do Fundecitrus, v.14, n.99, p.8-9, jul./ago. 2000 .

DAVIS, M.J.; PURCELL, A.H.; THOMPSON, S.V. Isolation media for the Pierce's disease bacterium. Phytopathology, v.70, p.425-429, 1980.

DAY, M.F.; IRZYKIEWICZ, H.; Mc KINNON, A. Observations of the feeding of the virus vector Orosius argentatus (Evans) and comparisons with certain other Jassids. Australian Journal Science Research, v.5, p.128-142, 1952.

DE NEGRI, J.D.; GARCIA JUNIOR, A. Sugestões para o manejo de pomares com clorose variegada dos citros. Laranja, v.14, n.1, p.255-267, 1993.

DESCOBERTOS mais seis vetores de CVC. Revista do Fundecitrus, v.14, n.94, p.8-9, ago./set. 1999.

ESAÚ, K. Anatomic effects of the viruses of Pierce's disease and phony peach. Hilgardia, v.18, n.12, p.423-464, 1948.

FRAZIER, N.W. Xylem viruses and their insect vectors. In: INTERNATIONAL CONFERENCE ON VIRUS AND VECTOR ON PERENIAL HOSTS, WITH SPECIAL REFERENCE TO VITIS, Davis, 1965. Proceedings. Davis: University of California, 1965. p.91-99.

FREITAG, J.H. Host range of the Pierce's disease virus of grapes as determined by insect transmission. Phytopathology, v.41,p.920-934, 1951.

FRY, S.M.; MILHOLLAND, R.D. Multiplication and translocation of Xylella fastidiosa in petioles and stems of grapevine resistant, tolerant, and susceptible to Pierce's disease. Phytopathology, v.80, p.61-65, 1990. 
FUNDECITRUS. Manual de convivência com a CVC. 2.ed. Araraquara: Centro de Pesquisas Citrícolas, 1998, 15p.

GARCIA JUNIOR, A.; LOPES, J.R.S.; BERETTA, M.J.G. Population survey of leafhopper vectors of Xylella fastidiosa in citrus nurseries, in Brazil. Fruits, v.52, n.6, p.371-374, 1997.

GOODWIN, P.H.; De VAY, J.E.; MEREDITH, C.P. Physiological responses of Vitis vinifera cv. 'Chardonnay' to infection by the Pierce's disease bacterium. Physiological and Molecular Plant Pathology, v.32, p.17-32, 1988.

GOTTWALD, T.R.; GIDTTI, F.D.; SANTOS, J.M.; CARVALHO, A.C. Preliminary spatial and temporal analysis of citrus variegated chlorosis (CVC) in São Paulo, Brazil. In: IOCV CONFERENCE, 12., Riverside, 1993. Proceedings. Riverside: International Organization of Citrus Virologists, 1993. p.327-335.

GRAVENA, S. Manejo ecológico de pragas dos citros - aspectos práticos. Laranja, v.19, n.1, p.61-77, 1998.

GRAVENA, S.; DE NEGRI, J.D.; QUAGGIO, J.A.; GONZALEZ, M.A.; PINTO, W.B.S.; BASILE, G.B. Manejo de cigarrinhas e CVC no pomar. In: DONADIO, L.C.; MOREIRA, C.S. (Ed.) Clorose variegada dos citros. Bebedouro: FUNDECITRUS, 1997. cap.6, p.93-112.

HILL, B.L.; PURCELL, A.H. Acquisition and retention of Xylella fastidiosa by an efficient vector, Graphocephala atropunctata. Phytopathology, v.85, n.2, p.209212, 1995a.

HILL, B.L.; PURCELL, A.H. Multiplication and movement of Xylella fastidiosa within grapevine and four other plants. Phytopathology, v.85, n.11, p.1368-1372, $1995 \mathrm{~b}$. 
HILL, B.L.; PURCELL, A.H. Populations of Xylella fastidiosa in plants required for transmission by an efficient vector. Phytopathology, v.87, n.12, p.1197-1201, 1997.

HOFFMAN, G.D.; HOGG, D.B. Potato leafhopper (Homoptera: Cicadellidae) in waterstressed alfalfa: population consequences and field tests. Environmental Entomology, v.20, n.4, p.1067-1073, 1991.

HOPKINS, D.L. Seasonal concentration of the Pierce's disease bacterium in grapevine stems, petioles, and leaf veins. Phytopathology, v.71, p.415-418, 1981.

HOPKINS, D.L. Physiological and pathological characteristics of virulent and avirulent strains of the bacterium that causes Pierce's disease of grapevine. Phytopathology, v.75, p.713-717, 1985.

HOPKINS, D.L. Xylella fastidiosa: xylem-limited bacterial pathogen of plants. Annual Review of Phytopathology, v.27, p.2711-3290, 1989.

HOPKINS, D.L.; ADLERZ, W.C. Natural hosts of Xylella fastidiosa in Florida. Plant Disease, v.72, p.429-431, 1988.

HOPKINS, D.L.; MOLLENHAUER, H.H. Rickettsia-like bacterium associated with Pierce's disease of grapes. Science, v.179, p.298-300, 1973.

HOPKINS, D.L.; THOMPSON, C.M. Seasonal concentration of the Pierce's disease bacterium in 'Carlos' and 'Welder' muscadine grapes compared with 'Schuyler' bunch grape. HortScience, v.19, n.3, p.419-420, 1984. 
HUANG, G.F.; CHIARADIA, L.A. Clorose variegada dos citros: caracterização e alternativas no manejo da doença. Agropecuária Catarinense, v.11, n.4, p.52-55, 1998.

KITAJIMA, E.W.; BAKARCIC, M.; FERNANDEZ-VALIEGA, M.V. Association of rickettsia like bacteria with plum leaf scald disease. Phytopathology, v.65, p.476$479,1975$.

KLEINN, C.; JOVEL, J.; HILJE, L. A model for assessing the effect of distance on disease spread in crop fields. Crop Protection, v.18, p.609-617, 1999.

KRÜGNER, R.; LOPES, M.T.V.C.; SANTOS, J.S.; BERETTA, M.J.G.; LOPES, J.R.S. Transmission efficiency of Xylella fastidiosa by sharpshooters and identification of two new vector species. In: CONFERENCE OF THE INTERNATIONAL ORGANIZATION OF CITRUS VIROLOGISTS, 14., Campinas, 1998. Programme and abstracts. Cordeirópolis: IAC, 1998. p.81.

LARANJEIRA, F.F. Dinâmica espacial e temporal da clorose variegada dos citros. Piracicaba, 1997. 144p. Dissetação (Mestrado) - Escola Superior de Agricultura "Luiz de Queiroz", Universidade de São Paulo.

LARANJEIRA, F.F.; POMPEU JUNIOR; J.; HARAKAVA, R. Seleção de variedades de citros tolerantes e/ou resistentes à clorose variegada dos citros. Fitopatologia Brasileira, v.20, p.304, 1995. Suplemento.

LARANJEIRA, F.F.; POMPEU JÚNIOR, J.; HARAKAVA, R.; FIGUEIREDO, J.O.; CARVALHO, S.A.; COLETTA FILHO, H.D. Cultivares e espécies cítricas hospedeiras de Xylella fastidiosa em condições de campo. Fitopatologia Brasileira, v.23, n.2, p.147-154, 1998. 
LEE, R.F.; BERETTA, M.J.G.; DERRICK, K.S; HOOKER, M.E. Development of a serological assay for citrus variegated chlorosis - a new disease of citrus in Brazil. Proceedings of the Florida State for Horticultural Society, v.105, p.32-35, 1992.

LEE, R.F.; BERETTA, M.J.G.; HARTUNG, J.H.; HOOKER, M.E.; DERRICK, K.S. Citrus variegated chlorosis: confirmation of Xylella fastidiosa as the causal agent. Summa Phytopathologica, v.19, n.2, p.123-125, 1993.

LEITE JÚNIOR, R.P.; LEITE, R.M.V.B.C. Associação de Xylella fastidiosa com clorose variegada dos citros. Summa Phytopathologica, v.17, p.7, 1991. /Resumo/

LEITE JÚNIOR, R.P.; HUANG, G.F.; UENO, B. Ocorrência da clorose variegada dos citros causada por Xylella fastidiosa no Estado de Santa Catarina. Fitopatologia Brasileira, v.21, p.335, 1996. Suplemento.

LELLIOTT, R.A.; STEAD, D.E. Methods for the diagnosis of bacterial diseases of plants. Boston: Blackwell Scientific Publications, 1987. 216p. (Methods in Plant Pathology, 2)

LEU, L.S.; SU, C.C. Isolation, cultivation and pathogenicity of Xylella fastidiosa, the causal bacterium of pear leaf scorch disease in Taiwan. Plant Disease, v.77, n.6, p.642-646, 1993.

LIMA, J.E.O. de Como conviver com o amarelinho. Revista do Fundecitrus, n.77, p.1-12, jul./ago. 1996.

LOPES, J.R.S. Mecanismos de transmissão de Xylella fastidiosa por cigarrinhas. Laranja, v.17, n.1, p.79-92, 1996. 
LOPES, J.R.S. Estudos com vetores de Xylella fastidiosa e implicações no manejo da clorose variegada dos citros. Laranja, v.20, n.2, p.329-344, 1999.

LOPES, J.R.S.; GIUSTOLIN, T.A. Outros hospedeiros das cigarrinhas. Revista do Fundecitrus, n.97, p. 1-15, mar./abr. 2000.

LOPES, J.R.S.; BERETTA, M.J.G.; HARAKAVA, R.; ALMEIDA, R.P.P.; KRÜGNER, R.; GARCIA JUNIOR., A. Confirmação da transmissão por cigarrinhas do agente causal da clorose variegada dos citros, Xylella fastidiosa. Fitopatologia Brasileira, v.21, p.343, 1996. Suplemento.

MACHADO, E.C.; QUAGGIO, J.A.; LAGÔA, A.M.M.A.; TICELLI, M.; FURLANI, P.R. Trocas gasosas em relações hídricas em laranjeiras com clorose variegada dos citros. Revista Brasileira de Fisiologia Vegetal, v.6, n.1, p.53-57, 1994.

MALAVOLTA, E.; PRATES, H.S.; VITTI, G.C.; PINTO, W.B.S. Novas observações sobre o "amarelinho" ou clorose variegada dos citros. Laranja, v.14, n.1, p.117200, 1993.

MARTINS, M.L.; CEOTTO, G.; ALVES, S.G.; BUFON, C.C.B.; SILVA, J.M.; LARANJEIRA, F.F. Cellular automata model for citrus variegated chlorosis. Physical Review, v.62, n.5, nov. 2000. /No prelo/

MINSAVAGE, G.V.; THOMPSON, C.M.; HOPKINS, D.L.; LEITE, R.M.V.B.C.; STALL, R.E. Development of a polimerase chain reaction protocol for detection of Xylella fastidiosa in plant tissue. Phytopathology, v.84, n.5, p.456-461, 1994.

MIZUBUTI, E.S.G.; MATSUOKA, K.; PARIZZI, P. Associação de bactéria do tipo Xylella em laranjeiras com sintomas de clorose variegada na região da Zona da Mata de Minas Gerais. Fitopatologia Brasileira, v.19, n.2, p.241-244, 1994. 
NELSON, S.C. A simple analysis of disease foci. Phytopathology, v.86, p.332-339, 1996.

NOMÉ, S.F.; RAJU,B.C.; GOHEEN, A.C.; NYLAND, G.; DOCAMPO, D. Enzymelinked immunosorbent assay for Pierce's disease bacteria in plant tissues. Phytopathology, v.70, p.746-749, 1980.

OLIVEIRA, P.S.R. de; SILVA, S.M.; ANGELOTTI FILHO, E. Clorose variegada dos citros. Unimar Ciências, v.4, n.1, p.123-133, 1995.

PAIVA, P.E.B.; SILVA, J.L.da; GRAVENA, S.; YAMAMOTO, P.T. Cigarrinhas de xilema em pomares de laranja do estado de São Paulo. Laranja, v.17, n.1, p.41-54, 1996.

PALAZZO, D.A. Estimativas de perdas de laranja 'Natal' por clorose variegada dos citros. Laranja, v.14, n.1, p.211-216, 1993.

PALAZZO, D.A.; CARVALHO, M.L.V. Desenvolvimento e progresso da clorose variegada dos citros (CVC) em pomares de Colina, SP. Laranja, v.13, n.2, p.489$502,1992$.

PARADELA FILHO, O.; SUGIMORI, M.H.; RIBEIRO, I.J.A.; MACHADO, M.A.; LARANJEIRA, F.F.;GARCIA JUNIOR., A.; BERETTA, M.J.G. Primeira constatação em cafeeiro no Brasil, da Xylella fastidiosa causadora da clorose variegada dos citros. Laranja, v.16, n.2, p.135-136, 1995.

POLSON, A.; VON WECHMAR, M.B.; VAN REGENMORTELL, M.H.V. Isolation of viral IgY antibodies from yolks of immunized hens. Immunological Communications, v.9, n.5, p.475-493, 1980. 
POMPEU JÚNIOR, J.; LARANJEIRA, F.F.; HARAKAVA, R.; FIGUEIREDO, J.O. de; CARVALHO, S.A.; COLETTA FILHO, H.D. Detecção de sintomas de clorose variegada dos citros e Xylella fastidiosa em plantas cítricas infectadas em condição de campo. Laranja, v.19, n.2, p.321-330, 1998.

POOLER, M.R.; HARTUNG, J.S. Specific PCR detection and identification of Xylella fastidiosa strains causing citrus variegated chlorosis. Current Microbiology, v.31, p.377-381, 1995.

POOLER, M.R.; MYUNG, I.S.; BENTZ, J.;SHERALD, J.; HARTUNG, J.S. Detection of Xylella fastidiosa in potential insect vectors by immunomagnetic separation and nested polymerase chain reaction. Letters in Applied Microbiology, v.25, p.123126, 1997.

PURCELL, A.H. Spatial patterns of Pierce's disease in the Napa Valley. American Journal of Enology and Viticulture, v.25, p.162-167, 1974.

PURCELL, A.H. Role of the blue-green sharpshooter, Hordnia circellata, in the epidemiology of Pierce's disease of grapevines. Environmental Entomology, v.4, p.745-752, 1975.

PURCELL, A.H. Cold therapy of Pierce's disease of grapevines. Plant Disease Reporter, v.61, p.514-518, 1977.

PURCELL, A.H. Leafhopper vectors of xylem-borne plant pathogens. In: MARAMOROSCH, K.; HARRIS, K.F. Leafhopper vectors and plant disease agents. New York: Academic Press, 1979. p.603-625.

PURCELL, A.H. Almond leaf scorch: leafhopper and spittlebug vectors. Journal of Economic Entomology, v.73, p.834-838, 1980. 
PURCELL, A.H. Vector preference and inoculation efficiency as components of resistance to Pierce's disease in European grape cultivars. Phytopathology, v.71, p.429-435, 1981 .

PURCELL, A.H. Homopteran transmission of xylem-limited bacteria. In: HARRIS, K.F. (Ed.) Advances in vector research. New York: Springer-Verlag, 1989. cap.9, p.243-266.

PURCELL, A.H. Cigarrinhas na cultura de citros. In: SEMINÁRIO INTERNACIONAL DE CITROS, 3., Bebedouro, 1994. Anais. Campinas: Fundação Cargill, 1994. p.195-209.

PURCELL, A.H. Xylella fastidiosa, a regional problem or global threat? Journal of Plant Pathology, v. 79, n.2, p.99-105, 1997.

PURCELL, A.H.; ELKINTON, J.S. A comparison of sampling methods for leafhopper vectors of X-disease in California cherry orchards. Journal of Economic Entomology, v.73, n.6, p.854-860, 1980.

PURCELL, A.H.; FINLAY, A. Evidence for noncirculative transmission of Pierce's disease bacterium by sharpshooter leafhoppers. Phytopatology, v.69, n.4, p.393-395, 1979.

PURCELL, A.H.; HOPKINS, D.L. Fastidious xylem-limited bacterial plant pathogens. Annual Review of Phytopathology, v.34, p.131-151, 1996.

PURCELL, A.H.; SAUNDERS, S.R. Fate of Pierce's disease strains of Xylella fastidiosa in common riparian plants in California. Plant Disease, v.83, n.9, p.825-830, 1999. 
QUEIROZ-VOLTAN, R.B.; PARADELA FILHO, O. Caracterização de estruturas anatômicas de citros infectados com Xylella fastidiosa. Laranja, v.20, n.1, p.55-76, 1999.

RAJU, B.C.; GOHEEN, A.C.; FRAZIER, N.W. Occurence of Pierce's disease bacteria in plants and vector in California. American Phytopathology Society, v.73, n.9, p.1309-1313, 1983.

RAVEN, J.A. Phytophages of xylem and phloem: a comparison of animal and plant sapfeeders. Advances in Ecology Research, v.13, p.135-234, 1984.

ROBERTO, S.R. Flutuação populacional de cigarrinhas (Hemiptera: Cicadellidae) vetoras de Xylella fastidiosa em pomares de laranja doce no Estado de São Paulo. Jaboticabal, 1998. 106p. Tese (Doutorado) - Faculdade de Ciências Agrárias e Veterinárias, Universidade Estadual Paulista "Júlio de Mesquita Filho".

ROBERTO, S.R.; YAMAMOTO, P.T. Flutuação populacional e controle químico de cigarrinhas em citros. Laranja, v.19, n.2, p.269-284, 1998.

ROBERTO, S.R.; COUTINHO, A.; LIMA, J.E.O.; MIRANDA, V.S.; CARLOS, E.F. Transmissão de Xylella fastidiosa pelas cigarrinhas Dilobopterus costalimai, Acrogonia terminalis e Oncometopia fascialis em citros. Fitopatologia Brasileira, v.21, n.4, p.517-518, 1996.

ROBERTO, S.R.; COUTINHO, A.; LIMA, J.E.O.; MIRANDA, V.S.; CARLOS, E.F. Avaliação de métodos de monitoramento de cigarrinhas transmissoras da clorose variegada dos citros. Revista Brasileira de Fruticultura, v.19, n.2, p.227-233, 1997. 
ROBERTO, S.R.; DALLA PRIA JÚNIOR, W.; YAMAMOTO, P.T.; FELLIPE, M.R.; FREITAS, E.P.de Espécies e flutuação populacional de cigarrinhas em viveiros de citros, em Gavião Peixoto (SP). Laranja, v.21, n.1, p.65-79, 2000.

ROSSETTI, V; GONZALES, M.A.; DONADIO, L.C. Histórico. In: DONADIO, L.C.; MOREIRA, C.S. (Ed.) Clorose variegada dos citros. Bebedouro: FUNDECITRUS, 1997. cap.1, p.1-21.

ROSSETTI, V., GARNIER, M.; BOVÉ, M.J.; BERETTA, J.M.G.; TEIXEIRA, A.R.R.; QUAGGIO, J.A.; DE NEGRI, J.D. Présence de bactéries dans le xylème d'orangers atteints de chlorose variégée, une nouvelle maladie des agrumes au Brésil. Compte Rendy Academie Seances Paris, Ser. III, p. 345-349, 1990.

SALVA; R.A.; ROBERTO, S.R.; CARLOS, E.F. Situação da clorose variegada dos citros no Estado de São Paulo. Laranja, v.16, n.2, p.155-164, 1995.

SEMPIONATO, O.R.; GIROTTO, L.F.; STUCHI, E.S. Produção de mudas sadias. In: DONADIO, L.C.; MOREIRA, C.S. (Ed.) Clorose variegada dos citros. Bebedouro: FUNDECITRUS, 1997. cap.5, p.75-92.

SEVERIN, H.H.P. Transmission of the virus of Pierce's disease by leafhoppers. Hilgardia, v.19, p.190-202, 1949.

SHERALD, J.L.; LEI, J.D. Evaluation of a rapid ELISA test kit for detection of Xylella fastidiosa in landscape trees. Plant Disease, v.75, n.2, p.200-203, 1991.

SILVEIRA NETO, S.; NAKANO, O.; BARDIN, D.; VILLA NOVA, N. Manual de ecologia dos insetos. São Paulo: Agronômica Ceres, 1976. 419p. 
TIMMER, L.W.; LEE,R.F.; ALLEN, J.C.; TUCKER, D.P.H. Distribution od sharpshooters in Florida citrus groves. Environmental Entomology, v.11, n.2, p.456-460, 1982.

TRAVENSOLO, R.F.; LEITE JÚNIOR., R.P. Hospedeiros alternativos de Xylella fastidiosa entre plantas invasoras de pomares de citros com clorose variegada. Fitopatologia Brasileira, v.21, p.336, 1996. Suplemento.

TUBELIS, A.; BARROS, J.C.; LEITE, R.M.V.B. Difusão da clorose variegada dos citros em pomares comerciais de laranja no Brasil. Laranja, v.14, n.1, p.239-254, 1993.

TURNER, W.F.; POLLARD, H.N. Insect transmission of phony peach disease. Davis: USDA, 1959. 27p. (USDA. Technical Bulletin, 1193).

VAN REGENMORTEL, M.H.V.; DUBS, M.C. Serological procedures. In: MATTHEWS, R.E.F. (Ed.) Diagnosis of Plant Vírus Diseases. Boca Raton: CRC Press, 1993. Cap. 7, p.159-214.

VARNER, J.E.; HO, D.T. Hormones. In: BONNER, J.; VARNER, J.E. (Ed.) Plant biochemistry. New York: Academic Press, 1976. p.713-770.

WELLS, J.M.; RAJU, B.C.; NYLAND, G.; LOWE, S.K. Medium for isolation and growth of bacteria associated with plum leaf scald and phony peach diseases. Applied and Environmental Microbiology, v.42, p.357-363, 1981.

WELLS, J.M.; RAJU, B.C.; HUNG, H.Y.; WEISBERG, W.G.; MANDELCO-PAUL, L.; BRENNER, D.J. Xylella fastidiosa gen. nov., sp. nov: Gram-negative, xylemlimited fastidious plant bacteria related to Xanthomonas spp. International Journal of Systematic Bacteriology, v.37, n.2, p.136-143, 1987. 
YAMAMOTO, P.T. Cigarrinhas em citros no estado de são Paulo. Laranja, v.17, n.1, p.237-239, 1996. Suplemento.

YAMAMOTO, P.T. Espécies e flutuação populacional de cigarrinhas e psilídeos (Hemiptera) em pomares cítricos. Jaboticabal, 1998. 112p. Tese (Doutorado) Faculdade de Ciências Agrárias e Veterinárias, Universidade Estadual Paulista "Júlio de Mesquita Filho".

YONCE; C.E.; CHANG, C.J. Detection of xylem-limited bacteria from sharpshooter leafhoppers and their feeding hosts in peach environs monitored by culture isolaton and ELISA techniques. Environmental Entomology, v.16, p.68-71, 1987. 